\title{
A faunal survey in Kingu Pira (south Tanzania), with new karyotypes of several small mammals and the description of a new Murid species (Mammalia, Rodentia)
}

\section{Christiane DENYS \\ Aude LALIS}

Muséum national d'Histoire naturelle, Départment Systématique et Évolution, UMR 7205 CNRS-OSEB, case postale 51, 57 rue Cuvier, F-75231 Paris cedex 05 (France) denys@mnhn.fr

lalis@mnhn.fr

\section{Émilie LECOMPTE}

Université Paul Sabatier, UMR 5174 CNRS-Évolution et Diversité Biologique,

F-31062 Toulouse cedex 4 (France)

lecompt@cict.fr

\section{Raphaël CORNETTE \\ Sibyle MOULIN}

Muséum national d'Histoire naturelle, Départment Systématique et Évolution, UMR 7205 CNRS-OSEB, case postale 51, 57 rue Cuvier, F-75231 Paris cedex 05 (France)

cornette@mnhn.fr moulin@mnhn.fr

Rhodes H. MAKUNDI

Robert S. MACHANG'U

Sokoine University of Agriculture, Pest Management Center, P.O. Box 3110, Morogoro (Tanzania) rmakundi@suanet.ac.tz machangu@suanet.ac.tz

Vitaly VOLOBOUEV Muséum national d'Histoire naturelle, Départment Systématique et Évolution, UMR 7205 CNRS-OSEB, case postale 51, 57 rue Cuvier, F-75231 Paris cedex 05 (France) vitaly@mnhn.fr

\section{Vladimir M. ANISKINE}

Severtsov Institute of Ecology and Evolution, Russian Academy of Sciences, Leninskii pr 33, 117071, Moskow (Russia) anivlad@gmail.com 

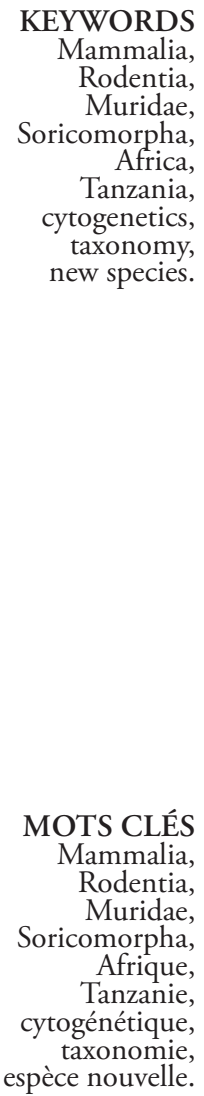

\begin{abstract}
A multidisciplinary approach combining morphology, classical morphometry and cytogenetics allowed to establish an updated taxonomic inventory of small mammals from Kingu Pira in the Selous region (south Tanzania). Among the 229 rodents and 21 shrews that were captured during the fieldwork in Ngarembe village in July 2003, 45 specimens were karyotyped. Concerning rodents, this allowed the description of a new karyotype of Acomys and Grammomys, while the cytotypes of Paraxerus flavovittis and Pelomys fallax are here figured for the first time. Taxonomic revisions of the literature allowed to clarify the status of Lemniscomys rosalia and Aethomys chrysophilus in Tanzania. Using a combination of morphological and cytogenetical characters, a new species of Grammomys is described. For shrews, we provide here the first description of $C$. hirta karyotype. Comparisons with voucher of genetically typed specimens of different east African collections confirmed the important biodiversity of this region for conservation and the necessity to preserve the coastal forest of south Tanzania.
\end{abstract}

\section{RÉSUMÉ}

Inventaire faunique dans la région de Kingu Pira (sud Tanzanie) et description de nouveaux caryotypes de petits mammiferes et d'une nouvelle espèce de rongeur Muridae (Mammalia, Rodentia).

Une approche multidisciplinaire combinant morphologie, morphométrie classique et cytogénétique nous permet d'établir un inventaire taxonomique actualisé des petits mammifères dans la région de Kingu Pira dans le Selous (Sud de la Tanzanie). Parmi les 229 rongeurs et 21 musaraignes capturés au cours d'une mission de terrain dans le village de Ngarembe en juillet 2003, 45 spécimens ont fait l'objet de caryotypes standard. Pour les rongeurs, nous avons pu décrire un nouveau caryotype d'Acomys et de Grammomys, tandis que les cytotypes de Paraxerus flavovittis et Pelomys fallax sont déterminés pour la première fois. Une révision des données de la littérature a permis de faire une mise au point sur le statut de Lemniscomys rosalia et Aethomys chrysophilus en Tanzanie. La combinaison des caractères morphologiques et cytogénétiques nous permet de décrire une nouvelle espèce de Grammomys. Pour les musaraignes, nous fournissons la première description du caryotype de C. hirta. La comparaison avec des spécimens de collections d'Afrique de l'Est ayant fait l'objet de typages génétiques confirme l'importante biodiversité de cette région pour la conservation et la nécessité de préserver la forêt côtière du Sud de la Tanzanie.

\section{INTRODUCTION}

Systematics has recently benefited from new biological techniques and concepts such as those developed in molecular phylogenetics, molecular cytogenetics or geometric morphometric analyses. The integration of all these techniques provides a powerful tool to more accurately identify small mammal taxa, which constitute about $80 \%$ of the mammalian biodiversity in Africa (Denys et al. 2003). Indeed, 
recent works have emphasized that the level of small mammal biodiversity is underestimated, especially in rodents, due to taxa being lumped because of similar morphology, whereas genetic divergence among these taxa is significant (Taylor 2000; Dobigny et al. 2003; Corti et al. 2004; Lecompte et al. 2005).

Due to the diversity of its habitats and environments, created, in part, by the major fault line of the Rift Valley extending from Ethiopian and Kenyan high plateaux to north Tanzania famous grasslands of the Serengeti, East Africa represents one "hotspot" of biodiversity (Myers et al. 2000). In this region, many high reliefs have also created islands of diversity, which have promoted speciation of all taxa (Kindgon 1974; Demeter \& Hutterer 1986; Goodman et al. 1995; Stanley et al. 1996, 1998; Clausnitzer \& Kityo 2001; Kasangaki et al. 2003; Carleton \& Stanley 2005; Huhndorf et al. 2007, Mulungu et al. 2008). Especially, new rodents and other small mammal species have recently been described in the eastern Arc Mountains of East and central Tanzania (Stanley \& Hutterer 2000; Carleton \& Stanley 2005; Stanley et al. 2005). Also, some isolated forests have preserved relict taxa of central Africa which considerably extend their geographical distribution (Stanley \& Foley 2008).

The southeastern region of Tanzania has received less attention until now; the relief is low and a coastal forest has developed in the plain of the Pwani and Lindi districts. The landscape is also fragmented by a succession of west-east flowing rivers which cross the landscape till the Mozambique border and are associated with permanent swamp regions. These rivers include the Wami, Rufiji and great Ruhaha, the Luwego, Mbenkuru, Lukuledi, the Rio Rovuma. The Rufiji river, which constitutes the northern border of the Selous Game Reserve, has the largest water catchment in east Africa, and massive amounts of silt flow into the Indian Ocean annually during the wet season. Surrounded by these rivers and limited to the east by some mountains and rift escarpment, the Selous Game Reserve is a 55000 square kilometres protected area and one of the largest game reserves in the world, established in 1922 (Fig. 1). The Selous has long been recognized as an important area for conservation of the large mammals. According to the definition of terrestrial ecoregions of the world by Olson et al. (2001), the Selous Game Reserve belongs to the eastern Miombo woodlands ecoregion and the northern and southern Zanzibar-Inhambane coastal forest mosaics, whose transition is not clear and has been situated at the Lukuledi River in south Tanzania, surround it in the east. The terrestrial small mammal biodiversity of the Selous Game Reserve is poorly known. The reserve is surrounded by geographic barriers such as rivers and mountains and has peculiar mosaic vegetation, which may hide underestimated cryptic small-mammal diversity.

Although previous small-mammal systematic surveys have been conducted either on the highlands zones of central Tanzania as cited above or in the Serengeti (north Tanzania) (Swynnerton 1958; Kingdon 1974; Lavrenchenko et al. 1998; Fadda et al. 2001; Corti et al. 2004, 2005) and from Zambia to South Africa (Burda 2001; Mullin et al. 2004), the small mammals from the Coastal region of southeastern Tanzania remain poorly known.

As a contribution to the knowledge of biodiversity of this region, we present here the results of a taxonomic inventory of terrestrial small mammals in the Kingu Pira zone at the eastern entrance of the Selous Game Reserve using a combined morphological, morphometric, cytogenetical and molecular approach. We aim to provide better discrimination between sibling species and bring new identification characters for future studies.

\section{MATERIAL AND METHODS}

Trapping took place from 5 to 10 July 2003. Rodents were captured using Sherman traps and by hand. Eight trap lines (A to $\mathrm{H}$ ) were run during three nights each (except line $\mathrm{G}$ and $\mathrm{H}$ which were maintained for 2 nights only) both in anthropogenic and natural environments. Lines $\mathrm{A}, \mathrm{B}$ and $\mathrm{C}$ were put in the vicinity of Ngarembe village in the residential area (Table 1, Fig. 2), lines D and E were situated in the logging area, lines $\mathrm{F}$ and $\mathrm{H}$ in the Kichi coastal forest and finally line $\mathrm{G}$ in the resident hunting area (Acacia woodland zone). Each trap line usually comprised 100 traps, placed $10 \mathrm{~m}$ apart. The baits used were 
peanut butter and maize flour with oil. The traps were checked every morning for night captures and re-baited each evening. About 10 additional traps were set with no standardized protocol and were distributed to people to be placed in houses.

All the animals captured were sacrificed using cervical dislocation, and autopsied by one of us (É. L.). Classical measurements (weight, head and body length, tail length, ear length and hind foot length with claws apart) were only taken by one of us in the field (É. L.); the reproductive condition was noted (testes position-scrotal or abdominal and size for males; opening of the vagina, presence of placental scars or embryos, and nipples appearance for females), as well as any other potentially informative detail. Organs (liver, kidney, spleen) were preserved in $90 \%$ ethanol for future molecular studies, and the carcasses were fixed in formalin for later preparation as skin and skull specimens. Except when stated, the nomenclature follows Wilson \& Reeder (2005).

Forty five specimens were kept for standard karyotypic analyses directly in the field by one of us (V. A.). Metaphase chromosome preparations were obtained by standard colchicine method according to protocols in Lee \& Elder (1980) and Seabright (1971). Few specimens were sequenced by one of us (É. L.) for fast molecular taxonomy identification (cyt B, BLAST).

Standard skull measurements were taken by one of us (C. D.) for each specimen by using a Mitutoyo calliper with a $0.01 \mathrm{~mm}$ resolution. Comparaisons were made either with the use of measurements made on type specimens or voucher specimens or using data from the litterature. The relative age of the specimens is examined through the weight and dental rows wear (Lalis et al. 2006). Drawings were made through a camera lucida on a binocular at 25 magnification. Standard descriptive and classical multivariate statistical analyses like principal component and canonical analyses were performed either on external measurements or skull distances using XLSTAT software version 7.1 (Addinsoft).

The whole series of voucher specimens is deposited in the collections of Muséum national d'Histoire naturelle, Paris under General catalogue numbers from CG2007-996 to CG2007-1261.

\author{
ABBREVIATIONS \\ Countries and localities \\ BEA British East Africa; \\ CAR Central African Republic; \\ DRC Democratic Republic of the Congo; \\ E Ethiopia; \\ EG Equatorial Guinea; \\ K Kenya; \\ KP Kingu Pira (Tanzania); \\ MA Malawi; \\ MZ Mozambique; \\ RSA Republic of South Africa; \\ S Sudan; \\ SO Somalia; \\ TZ Tanzania; \\ Z Zimbabwe.
}

\section{Institution}

BMNH Natural History Museum, London;

DM Durban Natural Science Museum;

FMNH Field Museum of Natural History, Chicago;

MNHN Muséum national d'Histoire naturelle, Paris;

NMH Natural History Museum, London;

SMMN National Museum of Namibia, Windhoek;

TM Transvaal Museum, Pretoria;

ZFMK Museum Alexander Koenig, Bonn;

ZMB Berlin Museum für Naturkunde.

\section{Karyotype}

2n

$\mathrm{AC}$

$\mathrm{FN}$

$\mathrm{FNa}$

$\mathrm{MC}$

SM

ST

diploid number of chromosomes;

acrocentric chromosome;

fundamental number of chromosomal arms;

number of autosomal arms;

metacentric chromosome;

submetacentric chromosome;

subtelomeric chromosome.

\section{External measurements}

E ear length;

HB head and body length;

HF hindfoot length;

TL tail length;

W body weight.

\section{Skull measurements}

$\mathrm{CIO} \quad$ width of the interorbital constriction;

HMDB height of the mandible;

LI13 length of the lower molar row;

LBT length of the tympanic bulla;

LGT greatest length of the skull;

LFOINC length of the incisor foramen;

LMDB length of the mandible;

LNAS length of the nasal bone;

LS13 length of the upper molar row;

WBR width of the braincase;

WNAS width of the nasal bone; 


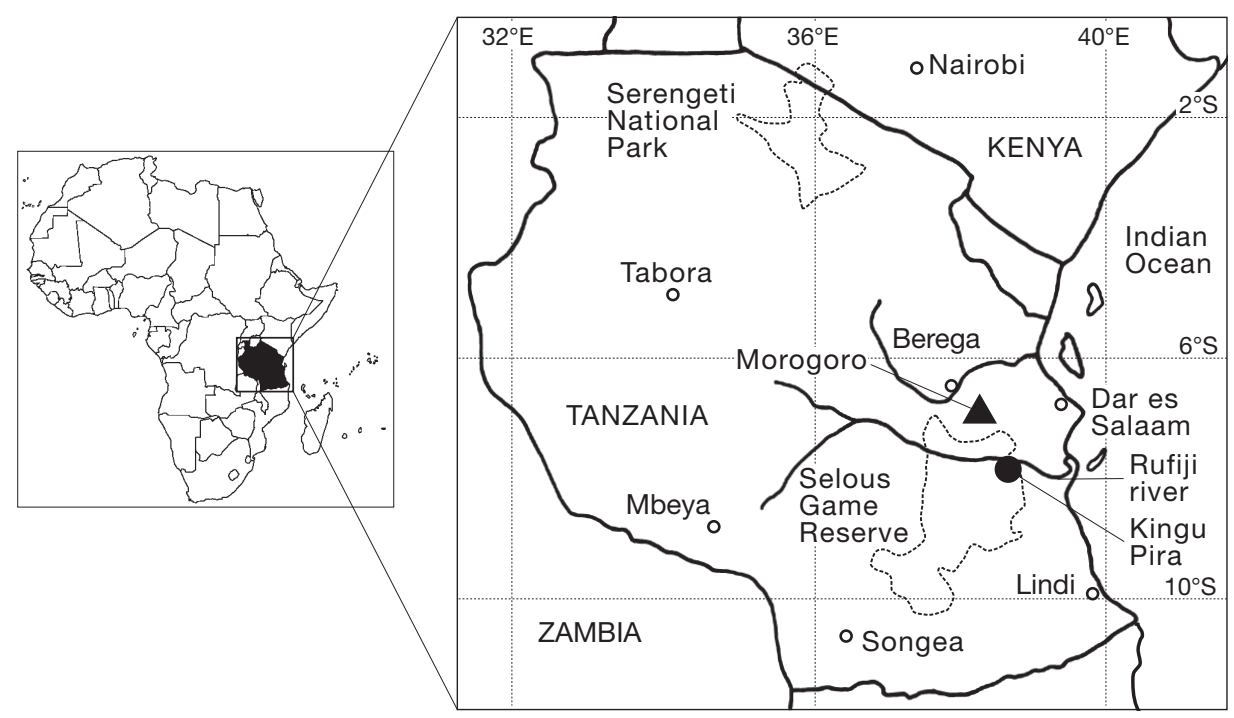

FIG. 1. - The study area in the vicinity of Kingu Pira, Tanzania, is located just south of Rufiji river at the entrance of the Selous Game

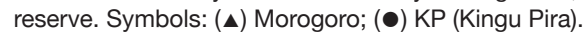

WT4 width of the palate between the two upper sel molars at the $t 4$ level;

WZYG bizygomatic width.

Species

ari

bal

bre

but

can

com

dis

dol

dry

elg

gaz

gig

ibe

ins

kem

lut

mac

$\min$

nat

poe

rut

sil
Grammomys aridulus Thomas \& Hinton, 1923;

Grammomys baliolus (Osgood, 1910);

Grammomys brevirostris Kryštufek, 2008;

Grammomys butingi Thomas, 1911;

Grammomys caniceps Hutterer \& Dieterlen, 1984;

Grammomys cometes Thomas \& Wroughton, 1908;

Grammomys discolor (Thomas, 1910);

Grammomys dolichurus Smuts, 1832;

Grammomys dryas Thomas, 1907;

Grammomys gazellae Thomas, 1910;

Grammomys gigas Dollman, 1911;

Grammomys ibeanus Osgood, 1910;

Grammomys insignis (Thomas, 1911);

Grammomys kempi Dollman, 1911;

Grammomys s. lutosus Dollman, 1911;

Grammomys macmillani (Wroughton, 1907);

Grammomys minnae Hutterer \& Dieterlen, 1984;

Grammomys natalensis Smith, 1834;

Grammomys poensis (Eisentraut, 1965);

Grammomys rutilans Peters, 1876;

Grammomys silidensis Roberts, 1938;
Grammomys s. elgonis (Thomas, 1910); sel Grammomys selousi n. sp.;

spo Grammomys spoliomops Osgood, 1910;

sur Grammomys surdaster Thomas \& Wroughton, 1908 ;

usa Grammomys usambarae (Matschie, 1915).

Specimen

HT holotype;

PT paratype;

$T$ type;

TS types species.

Statistics

CVA canonical variance analysis;

$\mathrm{N}$ number of individuals;

PCA principal component analysis;

SD standard deviation.

\section{RESULTS}

\section{TRAPPINGS}

Details of vegetation and captures of each line are provided in Table 1. A total of 250 rodents and shrews was obtained in 1967 night-traps which represents a trapping success of $12.7 \%$. Trapping success and species composition varied considerably between lines (Table 1). In fields and fallow zones (lines A, B, C, and E) Mastomys was dominant and constitutes $80 \%$ 
TABLE 1. - Kingu Pira line trapping success per species, trap line and habitat description and GPS coordinates. Abbreviations: $\mathbf{N}$, individual occurrence in each line; \%, percentage of captured individuals of each taxa per line compared to the whole number of captures; Night traps, number of traps per line $\times$ number of nights; Trapping success, number of captures / number of night traps $\times 100$; Mean TS, average trapping success for the whole lines.

\begin{tabular}{|c|c|c|c|}
\hline Trapping line and species & $\mathbf{N}$ & $\%$ & Trap line and habitat description \\
\hline $\begin{array}{l}\text { Line A } \\
\text { Crocidura hirta Peters, } 1852 \\
\text { Mastomys natalensis Smith, } 1834 \\
\text { Rattus rattus Linnaeus, } 1758 \\
\text { Total captures }\end{array}$ & $\begin{array}{r}3 \\
63 \\
1 \\
67 \\
\end{array}$ & $\begin{array}{r}1.2 \\
25.2 \\
0.4\end{array}$ & $\begin{array}{l}\text { Maize field close to village } \\
08^{\circ} 26^{\prime} 53^{\prime \prime} \mathrm{S}, 38^{\circ} 36^{\prime} 48^{\prime \prime} \mathrm{E} \\
\text { Night traps: } 200 \\
\text { Trapping success: } 32.5 \%\end{array}$ \\
\hline $\begin{array}{l}\text { Line B } \\
\text { Crocidura hirta } \\
\text { Mastomys natalensis } \\
\text { Total captures }\end{array}$ & $\begin{array}{r}3 \\
67 \\
70\end{array}$ & $\begin{array}{r}1.2 \\
26.8\end{array}$ & $\begin{array}{l}\text { River bed close to fields } \\
08^{\circ} 26^{\prime} 52 \text { "'S, } 38^{\circ} 36^{\prime} 46^{\prime \prime} \mathrm{E} \\
\text { Night traps: } 300 \\
\text { Trapping success: } 23.33 \%\end{array}$ \\
\hline $\begin{array}{l}\text { Line C } \\
\text { Gerbilliscus leucogaster (Peters, 1852) } \\
\text { Lemniscomys rosalia Thomas, 1904 } \\
\text { Mastomys natalensis } \\
\text { Mus minutoides Smith,1834 } \\
\text { Total captures }\end{array}$ & $\begin{array}{r}1 \\
1 \\
54 \\
1 \\
57\end{array}$ & $\begin{array}{r}0.4 \\
0.4 \\
21.6 \\
0.4\end{array}$ & $\begin{array}{l}\text { Bush-fallow close to the village } \\
08^{\circ} 26^{\prime} 52^{\prime \prime S}, 38^{\circ} 36^{\prime} 46^{\prime \prime} \mathrm{E} \\
\text { Night traps: } 267 \\
\text { Trapping success: } 21.35 \%\end{array}$ \\
\hline $\begin{array}{l}\text { Line D } \\
\text { Acomys sp. } \\
\text { Aethomys chrysophilus de Winton, } 1897 \\
\text { Crocidura hirta } \\
\text { Mastomys natalensis } \\
\text { Mus minutoides } \\
\text { Pelomys fallax Peters, } 1852 \\
\text { Total captures }\end{array}$ & $\begin{array}{r}2 \\
1 \\
14 \\
25 \\
1 \\
1 \\
44\end{array}$ & $\begin{array}{l}0.8 \\
0.4 \\
5.6 \\
10 \\
0.4 \\
0.4\end{array}$ & $\begin{array}{l}\text { Swamp close to cultivated fields and bush } \\
08^{\circ} 26^{\prime} 10^{\prime \prime} \mathrm{S}, 38^{\circ} 38^{\prime} 111^{\prime \prime} \mathrm{E} \\
\text { Night traps: } 300 \\
\text { Trapping success: } 14.67 \%\end{array}$ \\
\hline $\begin{array}{l}\text { Line } \mathrm{E} \\
\text { Lemniscomys rosalia } \\
\text { Mastomys natalensis } \\
\text { Total captures }\end{array}$ & $\begin{array}{l}1 \\
4\end{array}$ & $\begin{array}{l}0.4 \\
1.6\end{array}$ & $\begin{array}{l}\text { Degraded woodland with recent fires } \\
08^{\circ} 26^{\prime} 13^{\prime \prime} \mathrm{S}, 38^{\circ} 38^{\prime} 09^{\prime \prime} \mathrm{E} \\
\text { Night traps: } 200 \\
\text { Trapping success: } 2.5 \%\end{array}$ \\
\hline $\begin{array}{l}\text { Line F } \\
\text { Beamys cf. hindei Thomas, } 1909 \\
\text { Grammomys selousi n. sp. } \\
\text { Hystrix sp. } \\
\text { Total captures } \\
\end{array}$ & $\begin{array}{l}3 \\
2 \\
5\end{array}$ & $\begin{array}{l}1.2 \\
0.8\end{array}$ & $\begin{array}{l}\text { Kichi coastal lowland forest } \\
08^{\circ} 17^{\prime} 30^{\prime \prime} \mathrm{S}, 38^{\circ} 39^{\prime} 10^{\prime \prime} \mathrm{E} \\
\text { Night traps: } 300 \\
\text { Trapping success: } 1.67 \%\end{array}$ \\
\hline $\begin{array}{l}\text { Line G } \\
\text { Crocidura hirta } \\
\text { Paraxerus flavovittis (Peters, 1852) } \\
\text { Total captures }\end{array}$ & $\begin{array}{l}1 \\
1 \\
2\end{array}$ & $\begin{array}{l}0.4 \\
0.4\end{array}$ & $\begin{array}{l}\text { Open woodland } \\
08^{\circ} 27^{\prime} 14^{\prime \prime} \mathrm{S}, 38^{\circ} 35^{\prime} 18^{\prime \prime} \mathrm{E} \\
\text { Night traps: } 200 \\
\text { Trapping success: } 1 \%\end{array}$ \\
\hline Total captures & 0 & & $\begin{array}{l}\text { Degraded coastal forest } \\
08^{\circ} 17^{\prime} 20^{\prime \prime} \mathrm{S}, 38^{\circ} 39^{\prime} 11^{\prime \prime} \mathrm{E} \\
\text { Night traps: } 200 \\
\text { Trapping success: } 0 \%\end{array}$ \\
\hline Total & 250 & 100 & Total night traps: 1967, Mean TS: 12.7 \\
\hline
\end{tabular}

to $96 \%$ of the captures. In line D, Mastomys was still dominant with $56.8 \%$ and it was absent from the more protected zones of lines $\mathrm{F}$ and $\mathrm{G}$.
Thirteen species were found to occur in the Kingu Pira area and there were more species of rodent than of Soricomorpha. Most of the rodents belong 
to the family Muridae with Mastomys natalensis Smith, 1834 , being highly dominant $(83.52 \%)$, followed by other Murinae and Deomyinae, in very low proportions (between $0.38 \%$ to $1.15 \%$ each) but representing high diversity including Aethomys, Acomys, Pelomys, Grammomys, Lemniscomys, Mus (Nannomys), and Rattus. The subfamilies Nesomyinae and Gerbillinae are represented by Beamys (1.15\%) and Gerbilliscus (0.77\%), respectively. Other families of rodents documented include Sciuridae, represented by Paraxerus (0.38\%), and Hystricidae, represented by Hystrix sp. (this taxon was not trapped but its quills were collected). In addition to trapped specimens, Paraxerus were also observed twice.

The second most abundant taxon was Crocidura, representing $8.4 \%$ of the captures (Table 1 ).

\section{SPECIFIC TAXONOMIC ACCOUNT}

The following accounts summarize specific morphological and karyological characteristics of each species trapped.

\section{Order RODENTIA Bowdich, 1821}

Family MURIDAE Illiger, 1811

Subfamily DeOMYINAE Thomas, 1888

Genus Acomys I. Geoffroy, 1838

\section{Acomys sp. indet.}

Tanzania hosts at least four species of spiny mice: Acomys ignitus Dollman, 1910, A. kempi Dollman, 1911, A. wilsoni Thomas, 1892, A. spinosissimus Peters, 1852 (Barôme et al. 2001). The A. spinosissimus complex may comprise at least 4 species according to Walter Verheyen (pers. comm.) and the separation of $A$. selousi de Winton, 1896 from A. spinosissimus was claimed by Barôme et al. (2001). Only one individual of spiny mouse was found in line D in herbs of a swamp zone which is an unusual habitat for the genus which prefers rocky areas. The belly is white and the dorsal pelage is orange-light brown. Its general size is medium and the tail rather long but slightly shorter than the HB. This last character eliminates A. wilsoni, which has a shorter tail (between 42

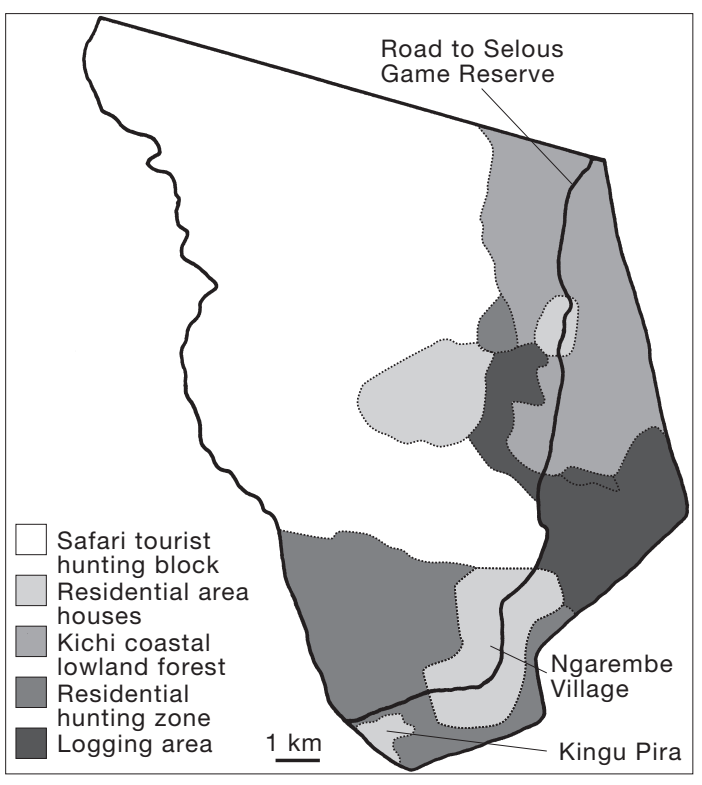

FIG. 2. - Map of the Ngarembe region with the resource zoning Plan. The road runs from north to south across the Kichi forest, a small residential area, the logging area, Ngarembe village, the residential hunting area and enters the Selous Game reserve at Kingu Pira barrier.

to $48 \mathrm{~mm}$ according to Kingdon (1974) and a smaller external size (Table 2). The Kingu Pira specimen is smaller than the $A$. spinosissimus holotype from Mozambique and has a similar HB but a smaller TL compared to the $A$. selousi holotype (Table 2).

The karyotype of the only female of Kingu Pira studied here is characterized by $2 \mathrm{n}=62$ and $\mathrm{FNa}=78$ (Fig. 3), which is close to that published by Fadda et al. (2001) and Corti et al. (2005) attributed to $A$. wilsoni. The slight differences in the FNa values, 78 vs. 76 , result from difficulty to distinguish between one small pair, which may be considered as subtelocentric or acrocentric. However both are different from the first description of chromosomes of $A$. wilsoni by Matthey (1968) who established $2 \mathrm{n}=60$ and $\mathrm{FNa}=70$ (Table 3). The karyotype of MNHN-CG2007-1230 is also different from that of $A$. cf. selousi from Berega (Tanzania) (Barôme et al. 2001), which may represent a new species (W. Verheyen pers. comm.), and from that of $A$. spinosissimus described by 
TABLE 2. - External measurements (in millimetres) of Acomys spp. Holotypes come from BMNH and ZMB; karyotyped or molecularly typed specimens from MNHN Paris collections are noted with an asterisk and some are listed from Barôme et al. (2001) and Matthey (1965). The 8 specimens of $A$. wilsoni are numbered CG1974-23, CG1974-25, CG1974-26, CG1974-28, CG1974-29, CG1974-31, CG1974-32 and CG1978-219. Abbreviations: see Material and methods.

\begin{tabular}{|c|c|c|c|c|c|c|}
\hline Species & Specimen & Country & HB & TL & $\mathbf{E}$ & HF \\
\hline Acomys sp. & MNHN-CG2007-1230 & Tanzania, KP & 80 & 61 & 14 & 15.5 \\
\hline A. spinosissimus Peters, 1852 & MNHN-CG1998-1611* & Tanzania & 91 & 73 & 14.7 & 15.1 \\
\hline A. spinosissimus & MNHN-CG1999-74* & Malawi & 94.5 & 87 & 16 & 16.5 \\
\hline A. spinosissimus & MNHN-CG99-36* & Malawi & 84.5 & 89 & 14 & 16 \\
\hline A. spinosissimus & Lectotype & Mozambique & 100 & 85 & 18 & 13.5 \\
\hline A. selousi de Winton, 1896 & MNHN-CG1964-53 & Tanzania & 80 & $53+$ & 15 & 17 \\
\hline A. selousi & BMNH 74.814 & Zambia & 82 & 72 & 15 & 18 \\
\hline A. selousi & Holotype & Zimbabwe & 83 & 92.5 & 16.5 & 14 \\
\hline A. selousi & BMNH 74.813 & Zambia & 84 & 67 & 15 & 16 \\
\hline A. selousi & BMNH 7.6.2.82 & Mozambique & 91 & 78 & 12 & 16 \\
\hline A. selousi & BMNH 7.6.2.81 & Mozambique & 93 & 87 & 15 & 17 \\
\hline A. selousi & BMNH 7.6.293 & Mozambique & 78 & 60 & 12 & 17 \\
\hline A. brockmani Dollman, 1911 & Holotype & Somalia & 105 & 105 & 18 & 17 \\
\hline A. wilsoni Thomas, 1892 & MNHN $(\mathrm{N}=8)$ & Ethiopia & 81.5 & 48.6 & 12.3 & 13.5 \\
\hline A. w. wilsoni & Holotype & Kenya & 80 & 48 & 8.5 & 12 \\
\hline A. w. argillaceus Hinton \&Kershaw, 1920 & Holotype & Sudan & 76 & 51 & 12 & 10 \\
\hline A. ablutus Dollman, 1911 & Holotype & Kenya & 77 & 55 & 12.5 & 13 \\
\hline A. ignitus Dollman, 1910 & Holotype & Kenya & 109 & 89 & 16.5 & 17 \\
\hline A. kempi Dollman, 1911 & Holotype & Kenya & 103 & 106 & 16 & 17 \\
\hline
\end{tabular}

TABLE 3. - Cytogenetical data for Acomys spp. from Kingu Pira compared with other literature data and to Dakawa (Morogoro region in Tanzania). We have kept the original names given by previous authors in the literature, pending a further revision of all the specimens to clarify the taxonomic situation. Abbreviations: see Material and methods.

\begin{tabular}{lllll}
\hline Taxon/specimen & 2n & FNa & Origin & Authors \\
\hline $\begin{array}{l}\text { Acomys sp. MNHN-CG2007- } \\
1230\end{array}$ & 62 & 78 & Tanzania, KP & this work \\
Acomys sp. & $60-61$ & $68-69$ & Tanzania & Barôme et al. 2001 \\
& 60 & 68 & Tanzania & Verheyen et al. unpubl. data \\
A. spinosissimus Peters, 1852 & $56-62$ & $68-75$ & Mozambique & Matthey 1965, 1968 \\
A. spinosissimus & 60 & 68 & South Africa & Dippenaar \& Rautenbach 1986 \\
A. cf. selousi de Winton, 1896 & 60 & 70 & Tanzania & Fadda et al. 2001; Corti et al. 2005 \\
& 36 & 66 & Ethiopia & Matthey 1968 \\
& 59 & 68 & Tanzania, Dakawa & Corti et al. 2005 \\
A. wilsoni Thomas,1892 & 60 & $76 ?$ (FN) & Ethiopia & Matthey 1968 \\
& 62 & 76 & Tanzania & Fadda et al. 2001; Corti et al. 2005 \\
Acomys sp. 1 & $59-60$ & 68 & Tanzania & Verheyen et al. unpubl. data \\
& $58-62$ & $68-76$ & Tanzania & Verheyen et al. unpubl. data \\
A. ignitus Dollman, 1910 & 50 & $66-70$ (FN) & Kenya & Matthey 1956, 1968 \\
A. cf.? ignitus & 36 & 68 & Tanzania & Fadda et al. 2001; Corti et al. 2005 \\
MNHN-CG2007-1258 & 61 & 68 & Tanzania, Dakawa & this work \\
MNHN-CG2007-1259 & 59 & 68 & Tanzania, Dakawa & this work \\
MNHN-CG2007-1261 & 59 & 68 & Tanzania, Dakawa & this work \\
\hline
\end{tabular}

Dippenaar \& Rautenbach (1986). It is also different from the karyotype of the so-called $A$. spinosissimus of south Tanzania and Masai steppe described by Fadda et al. (2001) and Corti et al. (2005) $(2 \mathrm{n}=60, \mathrm{FNa}=70)$. A thorough banding analysis is needed to elucidate the nature of 


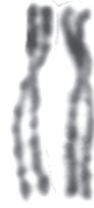

1

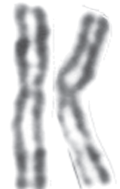

2

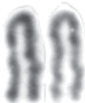

11

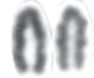

21

29

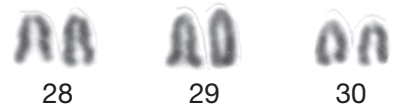

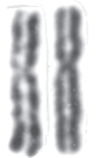

3

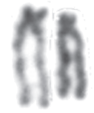

12

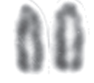

22

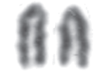

23

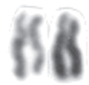

5

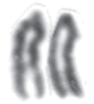

13

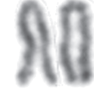

14

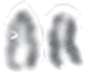

24

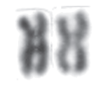

6

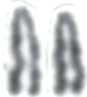

15

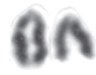

25

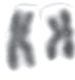

7

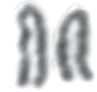

16

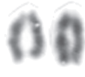

26

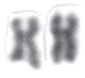

8

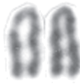

17

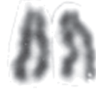

18

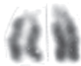

27

FIG. 3. - Standard karyotype of female Acomys sp. specimen (MNHN-CG2007-1230).

this mismatch. However, the type specimen of A. wilsoni comes from Mombasa (Kenya) and has different characters from the so-called $A$. wilsoni from Ethiopia karyotyped by Matthey (1968). We also found in Dakawa another karyotype which does not correspond to previous published ones (Table 3 ). The type specimens of $A$. selousi come from Zambia and that of $A$. spinosissimus from Mozambique.

By referring only to the type specimens of $A$. spinosissimus and $A$. wilsoni, as well as to specimens karyotyped by Matthey, from a morphological point of view, and according to preliminary $\mathrm{cyt} \mathrm{B}$ results, we assume that the specimens from Kingu Pira (and probably those of Fadda et al. [2001]) may belong to a new yet undescribed species. Further molecular and morphometric analyses are requested to definitively conclude on this identification problem (Verheyen et al. unpubl. data).
Subfamily MurinaE Illiger, 1811

Genus Aethomys Thomas, 1915

Aethomys chrysophilus (de Winton, 1852)

Mus chrysophilus de Winton, 1852: 801.

In Kingu Pira, line D provided one large Aethomys. In Tanzania $A$. hindei Thomas, 1902, A. kaiseri Noack, 1887 and A. chrysophilus de Winton, 1897 are coexisting (Kingdon 1974). In their revision of the $A$. hindei complex, Denys \& Tranier (1992) provided some criteria to separate between those species based on dental, skull and external morphology. The Kingu Pira specimen is attributed to A. chrysophilus due to the very long tail (Table 4), the characteristic skull and dental morphology (cf. Denys \& Tranier 1992). A CVA analysis performed upon the four external measurements including topotypes specimens of $A$. hindei (type locality of Machakos, Kenya) and A. chrysophilus from 
TABLE 4. - Measurements (in millimetres) for the external standard biometric characters of Aethomys chrysophilus de Winton, 1897 and A. hindei Thomas, 1902 populations. For A. hindei, specimens from Machakos (type locality, south Kenya) and Dakawa localities have been pooled. For A. chrysophilus, the southern specimens belong to the Tanzanian localities of Morogoro, Ruaha, Sangasanga, Songea, Mkundi and Dakawa, while the northern specimens all come from Kanyelele locality (Verheyen pers. comm.). Largest and smallest mean values are indicated in bold and italics respectively. Abbreviations: see Material and methods. Note: *, see legend for a list of localities.

\begin{tabular}{|c|c|c|c|c|c|c|c|}
\hline Taxon/specimen & Origin & Parameter & $\mathbf{W}$ & HB & TL & HF & $\mathbf{E}$ \\
\hline $\begin{array}{l}\text { A. chrysophilus } \\
\text { MNHN-CG2007-1248 }\end{array}$ & $\mathrm{KP}$ & & 60 & 124 & 166.5 & 27.5 & 21 \\
\hline A. chrysophilus & south localities * & $\begin{array}{l}\mathrm{N} \\
\text { Minimum } \\
\text { Maximum } \\
\text { Mean } \\
\text { SD }\end{array}$ & $\begin{array}{l}22 \\
27.0 \\
100.0 \\
64.718 \\
0.253\end{array}$ & $\begin{array}{c}22 \\
108.0 \\
152.0 \\
135.4 \\
0.081\end{array}$ & $\begin{array}{l}22 \\
130.0 \\
191.0 \\
\mathbf{1 6 2 . 0} \\
0.110\end{array}$ & $\begin{array}{l}22 \\
24.6 \\
29.5 \\
\mathbf{2 7 . 2} \\
0.047 \\
\end{array}$ & $\begin{array}{l}22 \\
17.2 \\
21.5 \\
19.2 \\
0.048\end{array}$ \\
\hline A. chrysophilus & north locality (Kan & $\begin{array}{l}\text { le) } \\
\mathrm{N} \\
\text { Minimum } \\
\text { Maximum } \\
\text { Mean } \\
\text { SD }\end{array}$ & $\begin{array}{l}11 \\
26.0 \\
72.0 \\
44.0 \\
0.340\end{array}$ & $\begin{array}{c}11 \\
101.0 \\
145.0 \\
121.6 \\
0.115\end{array}$ & $\begin{array}{c}11 \\
124.0 \\
170.0 \\
145.7 \\
0.093\end{array}$ & $\begin{array}{l}11 \\
24.8 \\
28.0 \\
26.7 \\
0.042 \\
\end{array}$ & $\begin{array}{l}11 \\
16.8 \\
19.8 \\
18.4 \\
0.061 \\
\end{array}$ \\
\hline A. hindei & Machakos and D & $\begin{array}{l}\text { N } \\
\text { Minimum } \\
\text { Maximum } \\
\text { Mean } \\
\text { SD }\end{array}$ & $\begin{array}{c}26 \\
25.0 \\
130.0 \\
79.9 \\
0.321\end{array}$ & $\begin{array}{c}26 \\
98.0 \\
168.0 \\
137.1 \\
0.141\end{array}$ & $\begin{array}{c}25 \\
91.0 \\
149.0 \\
127.6 \\
0.123\end{array}$ & $\begin{array}{l}26 \\
20.0 \\
31.0 \\
26.4 \\
0.099\end{array}$ & $\begin{array}{l}26 \\
16.0 \\
23.0 \\
20.1 \\
0.075\end{array}$ \\
\hline
\end{tabular}

northern and southern Tanzania displays a good distinction between the three groups (Fig. 4) with an overall rate of classification error of $13.56 \%$. All A. hindei were $100 \%$ well classified, against $99.76 \%$ of the $A$. chrysophilus for which one individual was classified as $A$. hindei. The most confusion occurred between north and south $A$. chrysophilus which have some overlap on the graph. On Figure 4, the Kingu Pira specimen is morphologically close to specimens of the Morogoro and southern Tanzanian localities attributed to A. chrysophilus. At Dakawa, the two species occur in sympatry. The chromosome formula of our Kingu Pira specimen is $2 \mathrm{n}=50$, $\mathrm{FNa}=58$, which corresponds unambiguously to the true $A$. chrysophilus from Zimbabwe and RSA according to Gordon \& Rautenbach (1980) and to $A$. cf. chrysophilus of north Tanzania found by Castiglia et al. (2003) and Fadda et al. (2001) (Table 5, Fig. 5). It is different from $A$. ineptus Thomas \& Wroughton, $1908(2 \mathrm{n}=44, \mathrm{FNa}=58)$ from Zimbabwe and South Africa and from $A$. kaiseri of Zambia $(2 n=50, F N a=60)$, which has very large sex chromosomes and 45 acrocentric chromosomes (Corti et al. 2005; Linzey \& Chimimba 2008).

\section{Genus Pelomys Peters, 1852}

\section{Pelomys fallax (Peters, 1852)}

\section{Mus (Pelomys) fallax Peters, 1852: 275.}

One relatively young individual was trapped in line $\mathrm{D}$ in herbs close to a waterhole. The skull displays grooved upper incisors, short nasal bones and a wide interorbital constriction, upper molars with large round cusps, which are relatively well aligned, and a large third upper molar, with one narrow posterior lobe that characterizes the genus. The only species recorded in Tanzania is Pelomys fallax. Comparisons with BMNH specimens of $P$. fallax from Uluguru Mountains (Tanzania) showed a larger size of external parts and skulls (Table 6). Comparison with the 


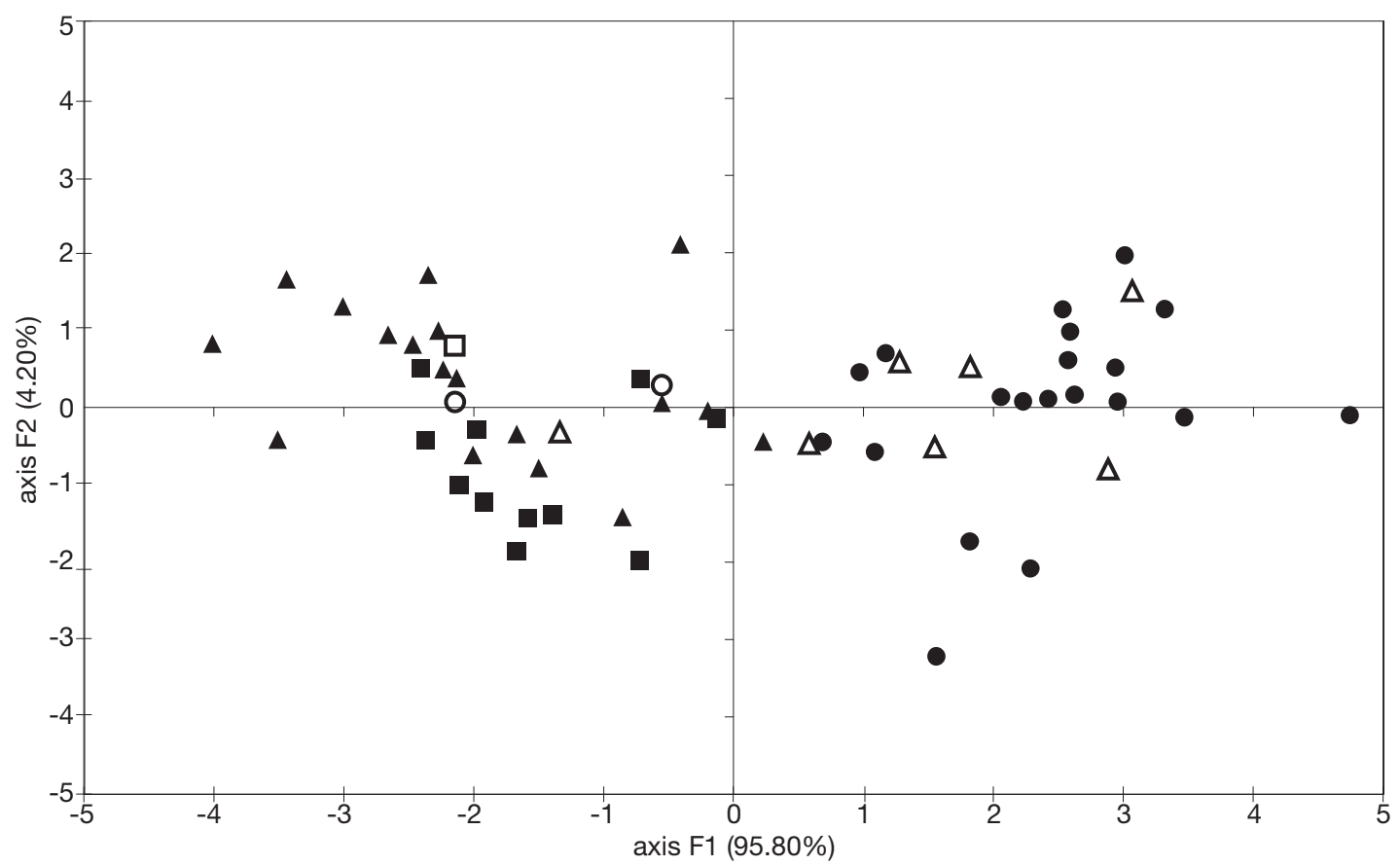

FIG. 4. - CVA performed on external measurements of Tanzanian Aethomys hindei Thomas, 1902 from Machakos (type locality) and Dakawa (•), A. chrysophilus de Winton, 1897 from Kanyelele (north Tanzania) ( $\square$ ) and A. chrysophilus from various localities further south $(\mathbf{\Delta})$, Morogoro (O), Kingu Pira $(\square)$ and Dakawa $(\Delta)$. The Dakawa locality has yielded both $A$. chrysophilus and $A$. hindei specimens.

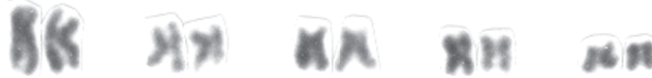 \\ 1 \\ 4 \\ 5}

2

3

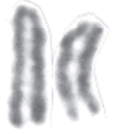

6

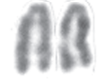

16

17

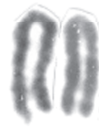

7

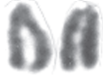

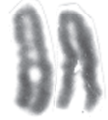

8

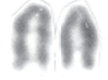

18

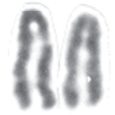

9

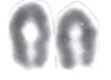

19

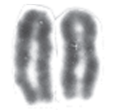

10

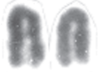

20

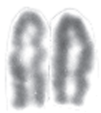

11

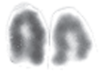

21

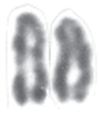

12

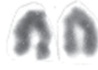

22

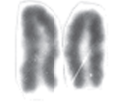

13

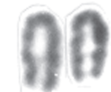

14

ก

24

XX

FIG. 5. - Standard karyotype of KP female Aethomys chrysophilus de Winton, 1897 specimen (MNHN-CG2007-1248). 
TABlE 5. - Cytogenetic data for Aethomys Thomas, 1915 of the A. chrysophilus de Winton, 1897 complex. Abbreviations: see Material and methods.

\begin{tabular}{|c|c|c|c|c|}
\hline Taxon/Specimen & $2 n$ & $\mathrm{FNa}$ & Origin & Authors \\
\hline \multicolumn{5}{|l|}{ A. chrysophilus } \\
\hline MNHN-CG2007-1248 & 50 & 58 & $\mathrm{KP}$ & this work \\
\hline A. ineptus Thomas \& & 44 & $50-58$ & 8 west Africa, South & Matthey 1958, 1964; Visser \& Robinson 1986; \\
\hline Wroughton, 1908 & & & Africa, Zimbabwe & $\begin{array}{l}\text { Gordon \& Watson 1986; Gordon \& Rautenbach 1980; } \\
\text { Chimimba \& Linzey } 2008\end{array}$ \\
\hline A. chrysophilus & 50 & 58 & $\begin{array}{l}\text { South Africa, Zimbabwe, } \\
\text { north Tanzania, }\end{array}$ & $\begin{array}{l}\text {, Gordon \& Watson 1986; Gordon \& Rautenbach 1980; } \\
\text { Fadda et al. 2001; Castiglia et al. } 2003\end{array}$ \\
\hline $\begin{array}{l}\text { A. bocagei } \\
\text { Thomas, } 1904\end{array}$ & 50 & $38-46$ & $\begin{array}{l}6 \text { west Africa, Zambia, } \\
\text { South Africa }\end{array}$ & $\begin{array}{l}\text { Matthey 1963, 1964; Visser \& Robinson 1986; } \\
\text { Castiglia et al. } 2003\end{array}$ \\
\hline A. kaiseri Noack, 1887 & 50 & 60 & Zambia & Castiglia et al. 2003; Corti et al. 2005 \\
\hline
\end{tabular}

type specimen of $P$. fallax from near the Zambezi River, Caya District, Mozambique, shows some similarities in size and morphology with the KP specimen in that it has the tail equal in length to head and body. However, the KP specimen is smaller than all other measured specimens but it has larger molars compared to the Angolan specimen and fits better with the Tanzanian specimens and the holotype (Table 7). All these results support the conclusions of Musser \& Carleton (2005) that $P$. fallax may represent a species complex.

The karyotype of the studied male has $2 \mathrm{n}=42$ and $\mathrm{FNa}=56$ (Fig. 6). As far as we know, the chromosome data are available for only one taxon of the genus, namely $P$. campanae Huet, 1888 (Matthey 1963) which displays $2 \mathrm{n}=48$ and $\mathrm{FNa}=52$ and is very distinct from that of the KP specimen.

\section{Genus Lemniscomys Trouessart, 1881}

\section{Lemniscomys rosalia Thomas, 1904}

Lemniscomys griselda rosalia Thomas, 1904: 414.

The single-striped mouse of the genus Lemniscomys found in fallow bush and degraded woodlands in KP displays only one dark median band on a yellow bright pelage which identifies it as a member of the species complex including L. zebra Heuglin, 1864, L. griselda Thomas, 1904 and L. rosalia Thomas, 1904. Van der Straeten (1980) has separated several species within this complex on a morphometric basis, and L. griselda is only known from Angola, Zambia, and DRC (Wilson \& Reeder 2005). Cytogenetic studies have shown that three species coexist in Tanzania: L. zebra, L. rosalia and L. striatus Linnaeus, 1758 (Fadda et al. 2001; Castiglia et al. 2002a; Corti et al. 2005). On a cytogenetic basis, Castiglia et al. (2002a) proposed without justification to rename the South African representatives of $L$. rosalia into L. calidior Thomas \& Wroughton, 1908, a decision that was not validated by Wilson $\&$ Reeder (2005).

By their general size and morphology the KP specimens are closer to the other Tanzanian specimens of $L$. rosalia from Berega (Tanzania) than to the South African specimens of Tembe Elephant Park, especially in the ear size and both populations may belong to distinct taxonomic units (Table 8).

Karyological data provide a $2 \mathrm{n}=54, \mathrm{FNa}=62$ for the two specimens of KP (Fig. 7) and these values do not correspond to $L$. rosalia from Tembe (South Africa) $(2 \mathrm{n}=48, \mathrm{FNa}=62)$ described by Ducroz et al. (1999) or L. zebra (Fadda et al. 2001; Castiglia et al. 2002a; Corti et al. 2005) from Tanzania $(2 \mathrm{n}=54, \mathrm{FNa}=58)$. But this karyotype corresponds to L. rosalia from Tanzania described by Castiglia et al. (2002a), Corti et al. (2005) and by Fadda et al. (2001) in northern Tanzania (Table 9).

Because the type locality of $L$. rosalia is Nguru Mts, Monda (Tanzania), we agree with Castiglia et al. (2002a) that the South African specimens called $L$. rosalia may represent a different species, 


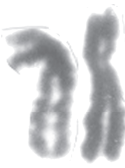

1

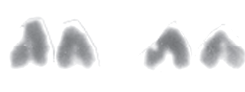

$9 \quad 10$

11

3
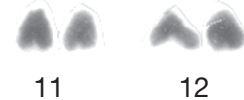

13

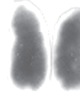

5
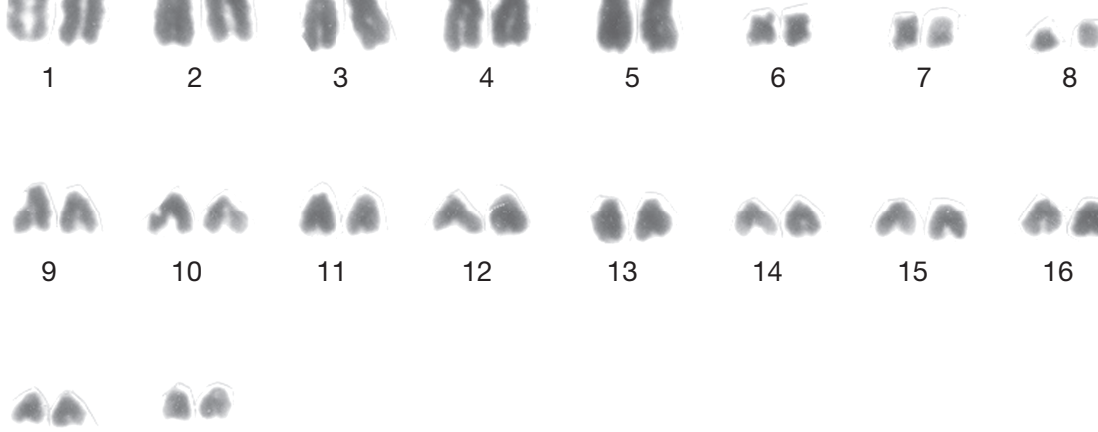

19

20
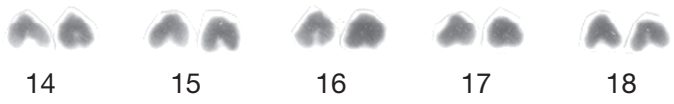

FIG. 6. - Standard karyotype of KP Pelomys fallax Peters, 1852 specimen (MNHN-CG2007-1247).

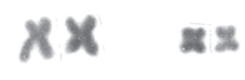

1

2
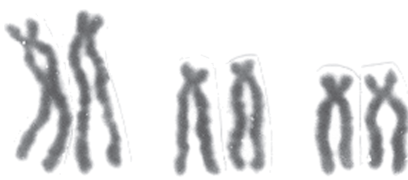

4

5
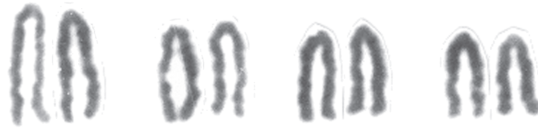

on

in $\sin (-100$

An

ก

$9 \quad 10$

11

12

13

hn

14

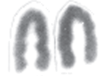

15
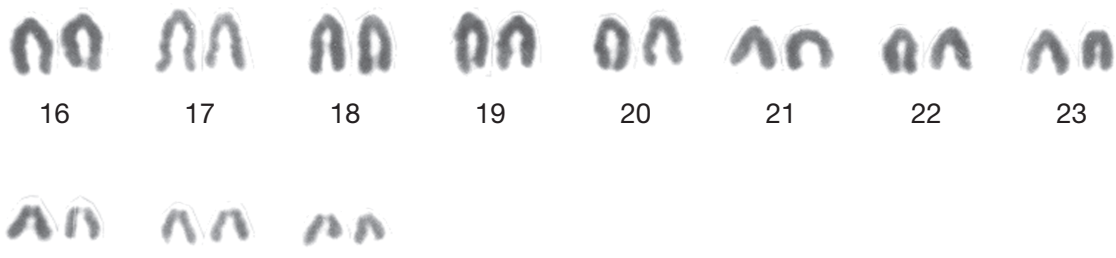

24

25

26

FIG. 7. - Standard karyotype of KP Lemniscomys rosalia Thomas, 1904 specimen (MNHN-CG2007-1206).

but without a careful examination of the type specimens of the various synonyms of L. griselda or of L. roseveari Van der Straeten, 1980 from
Zambia, we cannot here name the Kwazulu Natal karyotypic form described by Ducroz et al. (1999). We cannot follow the nomenclatural proposal of 
TABLE 6. - Measurements (in millimetres) of the standard external characters of Pelomys fallax Peters, 1852 specimens. Abbreviations: see Material and methods.

\begin{tabular}{llllll}
\hline Specimen & Country & HB & TL & HF & E \\
\hline ZMB 1675 Holotype & Mozambique & & & $24+$ & \\
MNHN-CG2007-1247 & Tanzania & 123.5 & 128.5 & 29 & 17 \\
BMNH 84.1794 & Tanzania & 158 & $151+$ & 31 & 21 \\
SMM4256 & Tanzania & 165 & 140 & 35 & 15 \\
SMM5498 & Angola & 152 & 152 & 29 & 19 \\
SMM5453 & Angola & 129 & 142 & 28 & 17 \\
SMM5458 & Angola & 131 & 136 & 28 & 16 \\
SMM5468 & Angola & 130 & 154 & 30 & 17 \\
SMM5469 & Angola & 141 & 150 & 30 & 18 \\
SMM5470 & Angola & 144 & 141 & 29 & 18 \\
SMM5471 & Angola & 136 & 146 & 30 & 18 \\
SMM5457 & Angola & 133 & 142 & 29 & 21 \\
\hline
\end{tabular}

TABlE 7. - Skull measurements (in millimetres) of Pelomys fallax Peters, 1852 specimens from different museums. Abbreviations: see Material and methods.

\begin{tabular}{|c|c|c|c|c|c|c|c|c|c|c|c|c|}
\hline Specimen & Country, District & LGT & WZYG & $\mathrm{ClO}$ & WNAS & LNAS & WBR & LS13 & LBT & LMDB & 3 HMD & LI13 \\
\hline \multicolumn{13}{|l|}{ ZMB 1675} \\
\hline $\begin{array}{l}\text { Holotype } \\
\text { MNHN-CG2007- }\end{array}$ & S Mozambique & & 15.30 & 4.80 & & & & 6.60 & & & & 6.38 \\
\hline 1217 & $\mathrm{TZ}, \mathrm{KP}$ & 31.68 & 15.90 & 5.41 & 462 & 1206 & 13.98 & 6.56 & 6.14 & 20.92 & 10.21 & 6.48 \\
\hline BMNH 34.8.26.6 & $T_{2}$ & 33.43 & 15.68 & 4.43 & & 13.68 & 13.80 & 3 & .25 & 20.99 & 10.71 & 6.49 \\
\hline $\begin{array}{l}\text { BMNH } 84.1794 \\
\text { BMNH }\end{array}$ & $\mathrm{TZ}, \mathrm{I}$ & 36.05 & 16.73 & 5.70 & 4.77 & 13.44 & 13.17 & 6.76 & 6.11 & 22.2 & 11.87 & 6.52 \\
\hline $\begin{array}{r}\text { Divi } \\
33\end{array}$ & is & 34.82 & 17.25 & 55 & 5.7 & 14.0 & \multicolumn{5}{|c|}{ BMNF } & 6.21 \\
\hline & $\begin{array}{lll}T & \end{array}$ & 37.65 & 17 & 14.15 & & & 1 & 8 & 5.45 & 2 & 12.58 & 7.65 \\
\hline & Ang & 34.40 & 15.29 & 13.00 & 5.0 & 5.09 & 13.62 & 6.30 & 6.27 & 21.68 & 11.46 & 6.07 \\
\hline & & 34.54 & 16.23 & 13.20 & 5.3 & 5.44 & 14.45 & 6.14 & 6.03 & 21.79 & 11.50 & 5.71 \\
\hline & & 33.73 & 16.41 & 12.68 & & 535 & 14.30 & 6.00 & 5.80 & 21.29 & 10 & 5.70 \\
\hline SMN & Ang & 34.44 & 16.62 & 12.70 & 5. & 5.31 & 14.73 & 6.03 & 6.16 & 22.58 & 11.38 & 5.90 \\
\hline & & 36.33 & 17.68 & 14.19 & 4. & 5.61 & 13.30 & 6.68 & 6.03 & 22.92 & 11.79 & 6.66 \\
\hline TM180 & Z & 36.42 & 17.45 & 14.04 & 4.63 & 5.66 & 13.67 & 6.81 & 6.43 & & & 6.67 \\
\hline
\end{tabular}

TABLE 8. - External standard measurements (in millimetres) of KP Lemniscomys rosalia Thomas, 1904, compared with other karyotyped Tanzanian and South African specimens. Abbreviations: see Material and methods.

\begin{tabular}{llllll}
\hline Specimen & HB & TL & HF & E & Locality/Country \\
\hline MNHN-CG2007-1206 & 131 & 140 & 27.5 & 16.5 & TZ, KP \\
MNHN-CG2007-1254 & 117 & $68+$ & 26 & 17 & TZ, KP \\
MNHN-CG1998-1610 & 120 & 125 & 24.9 & 15.5 & TZ, Berega \\
MNHN-CG1998-1609 & 130 & 152 & 24.3 & 15.8 & TZ, Berega \\
MNHN-CG1996-569 & 138 & 126 & 28 & 19 & RSA, Tembe \\
MNHN-CG1999-19 & 135 & $80+$ & 25.2 & 19 & RSA, Tembe \\
\hline
\end{tabular}

Castiglia et al. (2002a) and Corti et al. (2005) because the type specimen of $L$. calidior (Thomas \& Wroughton, 1908) came from Mozambique and not from South Africa. Similarly, these authors propose to give the name L. zebra for a given Tanzanian karyotype without any morphological or geographical justification (the oldest described?). Lemniscomys zebra was described from the Bahr 
el Ghazal (Sudan), which corresponds to a very different region and a distant one from Tanzania. Moreover, there are other available names from old descriptions of the L. griselda complex and pending their revision we will not propose synonymies for the South African and north Tanzanian forms.

Consequently, here we attribute the Selous specimen to L. rosalia s.s. due to its geographical proximity with the holotype, pending a further revision of this taxon.

Genus Mastomys Thomas, 1915

\section{Mastomys natalensis (Smith, 1834)}

Mus coucha natalensis Smith, 1834: 156.

In Tanzania, Mastomys is very abundant, especially in cultivated areas (Leirs et al. 1990; Lima et al. 2003). Different studies have shown that only $M$. natalensis is present in Tanzania.

This very common species was represented in our sample from KP by 217 individuals, of which 108 females and 109 males. Mastomys was found in all the trapping lines except the Kichi forest $(\mathrm{F})$ and the open woodland $(\mathrm{G})$. Some specimens were also trapped in houses. Among the females there are many juvenile specimens (eight with mass $<13 \mathrm{~g}$ and tooth wear stage 1), 29 had visible mammae with a weight greater than $34 \mathrm{~g}$, and none was pregnant. Among the males only four specimens reached a mass of $50 \mathrm{~g}$ and only two had scrotal testes. The composition of the present sampling reflects the biological cycle of the species in Tanzania (Lalis et al. 2006).

The results of microsatellite analyses revealed the absence of rupture in gene flow between individuals of Morogoro and Kingu Pira indicating that the Rufiji river and its swamp does not constitute a geographic barrier important enough to limit the crossing of Mastomys. They exchanged high gene flows by migration phenomenon and could belong to a single panmictic unit. This migratory flow contributed to genetic mixing which tends to homogenize the populations and to limit their genetic diversification (Lalis et al. 2009).
The karyotype of $M$. natalensis has been described repeatedly (Britton-Davidian et al. 1995; Granjon et al. 1997; Corti et al. 2005). It contains 32 chromosomes and FNa varying from 54 to 52, due to pericentric inversion of chromosome pair 14. In addition, this species is characterized by appreciable heteromorphism of two submetacentric pairs of autosomes resulting from addition/ deletion of $\mathrm{C}$ heterochromatin on the entirely heterochromatic short arms (Britton-Davidian et al. 1995). Four out of five KP specimens possess typical $M$. natalensis karyotype with $2 \mathrm{n}=32$ and $\mathrm{FNa}=54$. However the fifth individual appeared unusual by having variable chromosome number in different cells, namely $78 \%$ possess 33 and $12 \% 34$ chromosomes (the remaining 10\% have $2 n=32$ ). This variation is caused by the presence of supernumerary or B chromosomes which often display intercellular variation or mosaicism (Volobouev 1980). In addition, the sizes of both $\mathrm{X}$ and $\mathrm{Y}$ chromosomes was variable, due to polymorphism for addition/deletion of C heterochromatin (Fig. 8) never revealed before.

\section{Genus Grammomys Thomas, 1915}

The narrow-footed thicket rats of the genus Grammomys are arboreal rodents with very long tails ending with fine hairs at the tip. They differ from Thamnomys in dental characters (Thomas 1915; Heim de Balsac \& Aellen 1965; Misonne 1969; Rosevear 1969): postero-internal or " $x$ " cusp of the first and second molars reduced to a mere connecting ridge running from the inner cusp of the median lamina to the hinder point of the tooth (Thomas 1915: 150) and by having a wider and shorter hindfoot (Hutterer \& Dieterlen 1984). According to Kingdon (1974), G. dolichurus (Smuts, 1832) is found in Tanzania but it may be represented by three different forms, which have subsequently been elevated to species rank by Hutterer \& Dieterlen in 1984. These forms are $G$. cometes (Thomas \& Wroughton, 1908), G. dolichurus and G. macmillani (Wroughton, 1907). These authors also described a new species of the $G$. dolichurus complex: G. caniceps Hutterer \& Dieterlen, 1984 
TABLE 9. - Karyotypes of the single-stripped Lemniscomys Trouessart, 1881 species of Africa from literature data. Abbreviations: see Material and methods.

\begin{tabular}{|c|c|c|c|c|}
\hline Taxon/specimen & $2 n$ & $\mathrm{FNa}$ & Origin & Authors \\
\hline $\begin{array}{l}\text { L. rosalia MNHN-CG2007- } \\
1206 \& 1254\end{array}$ & 54 & 62 & KP & this work \\
\hline $\begin{array}{l}\text { L. bellieri Van der Straeten, } \\
1975\end{array}$ & 56 & 60 & west Africa & $\begin{array}{l}\text { Van der Straeten \& Verheyen 1978; Tranier \& Gautun } \\
1979\end{array}$ \\
\hline L. bellieri & 56 & ? & west Africa & Orlov et al. 1989 \\
\hline $\begin{array}{l}\text { L. macculus Thomas \& } \\
\text { Wroughton, } 1910\end{array}$ & 56 & 62 & CAR & Ducroz 1998 \\
\hline L. mittendorfi Eisentraut, 1968 & 56 & ? & Cameroon & Fülling 1992 \\
\hline $\begin{array}{l}\text { L. rosalia calidior Thomas \& } \\
\text { Wroughton, } 1908\end{array}$ & 48 & 62 & RSA, Tembe & Ducroz et al. 1999 \\
\hline L. rosalia Thomas, 1904 s.s. & 54 & 62 & Tanzania & $\begin{array}{l}\text { Fadda et al. 2001; Castiglia et al. 2002a; Corti et al. } \\
2005\end{array}$ \\
\hline L. cf. zebra (Heuglin, 1864) & 44 & $68 ?$ & N Tanzania & Fadda et al. 2001; Castiglia et al. 2002a \\
\hline L. zebra & 54 & 58 & N S Tanzania & Corti et al. 2005 \\
\hline
\end{tabular}

from north Kenya and south Somalia. Based on their morphology, Meester \& Setzer (1971-1977) keep the distinction between Grammomys and Thamnomys by using $\mathrm{t} 7$ cusp disposition on the upper M1/. They also provide a character to distinguish between $G$. rutilans Peters, 1876 (small t7 but visible) from $G$. cometes/G. dolichurus (crestiform t7 relating 44 to t8). Later, Petter \& Tranier (1975) showed that the morphology of the upper M3 molar reflects the important karyotypic diversity observed in the $G$. dolichurus group and recognized the distinction of the CAR G. gazellae (Thomas, 1910) today synonymyzed with G. macmillani. Musser \& Carleton (2005) confirmed the distinction of the genus Grammomys and following Hutterer \& Dieterlen (1984), restricted $G$. dolichurus to eastern and southern Africa, including subspecies in the montane areas of Nyika, Kilimanjaro and Elgon. The holotype of $G$. dolichurus, which is the type species of genus Grammomys, comes from Cape Town. No precisions about $G$. dolichurus occurrence in Tanzania are reported and limits of its geographical range remain unresolved according to Musser \& Carleton (2005). However, in Malawi, Hanney (1965) described $G$. dolichurus and $G$. cometes in south Malawi and Nyika Plateau. Grammomys cometes was described from a specimen from Inhambane, Mozambique and would be distributed according to Musser \& Carleton (2005) from SE Cape Province and
Mozambique south of the Zambezi river, and is an inhabitant of the savannah woodland biome in South Africa (Mugo et al. 1995). Grammomys macmillani, described from Ethiopia, would be present from Sierra Leone to Mozambique according to Musser \& Carleton (2005). This range extension of the species, compared to that indicated by Hutterer \& Dieterlen (1984), is based only upon morphology and it includes $G$. gazellae representatives of CAR karyotyped by Petter \& Tranier (1975). Also based upon morphological analysis of type specimens, Musser \& Carleton (2005) contrary to Hutterrer \& Dieterlen (1984) rehabilitated G. ibeanus Osgood, 1910 from Kenya and separated it from $G$. cometes series. According to Wilson \& Reeder (2005), G. ibeanus would be distributed from extreme NE Zambia, Malawi to highlands of eastern Tanzania and Kenya to southern Sudan. In Zambia and Tanzania, the complex G. surdaster Thomas \&Wroughton, 1908, that has been put in synonymy with $G$. dolichurus by Musser \& Carleton (2005), should comprise at least two chromosomal formulae $(2 \mathrm{n}=50-51$, $\mathrm{FNa}=61$ and $2 \mathrm{n}=42, \mathrm{FNa}=64)$, as described by Corti et al. (2005). For these authors, some Tanzanian specimens assigned to the G. butingi complex, without justification, would display a new karyotype. Finally, a new species of the genus was recently described in Kenya: G. brevirostris Kryštufek, 2008. 
A
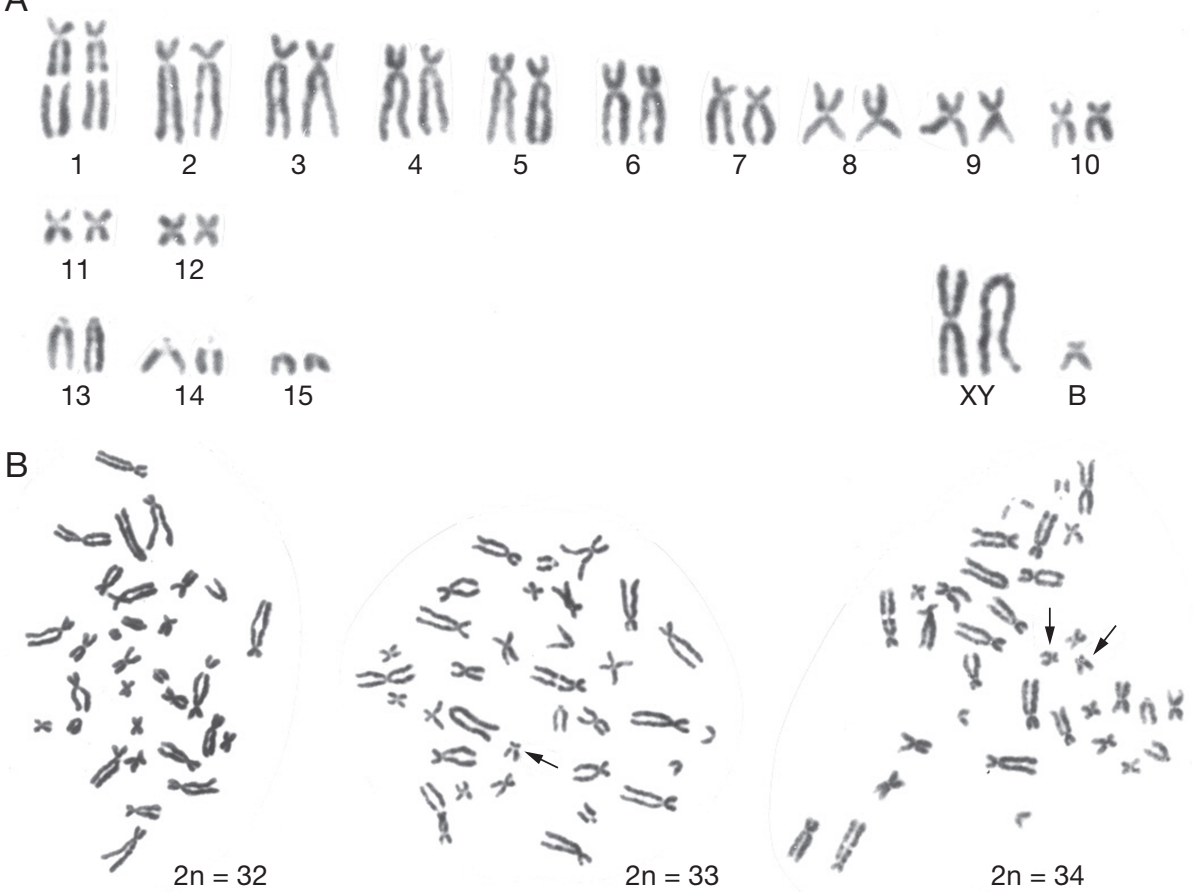

C
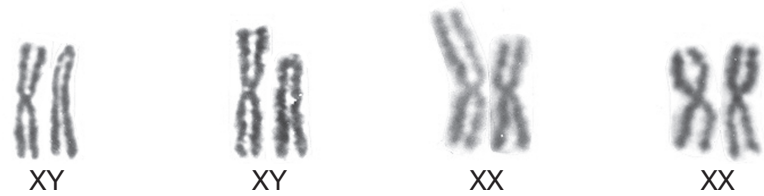

FIG. 8. - Standard karyotype of different Mastomys natalensis Smith, $1834 \mathrm{KP}$ specimens displaying variability: A, specimen MNHNCG2007-1015 ( $2 \mathrm{n}=33, \mathrm{FNa}=56$, B: supplementary chromosome); $\mathbf{B}$, variability of the $2 \mathrm{n}$ number with arrows indicating the supernumerary chromosomes; C, variability of the sexual chromosomes of specimens (MNHN-CG2007-1016, 2007-1144, 2007-1205, 2007-1237).

Grammomys selousi n. sp.

(Figs 9-16)

TYPe MATERIAL. - Tanzania. Holotype: Kingu Pira, Kichi Forest, line F, 8.VII.2003, 1 adult O’ KP171 (MNHN-CG2007-1231).

Paratype: same site as holotype, 9.VII.2003, 1 young ơ KP186 (MNHN-CG2007-1252).

Both specimens have been prepared as skin, skull, liver in ethanol, fibroblast cultures. External dimensions are summarized in Table 10, skull dimensions in Table 11. Standard karyotype is displayed in Figure 11.

TYPe LoCality. - Tanzania, Lindi Region, Ngarembe village, Kichi Forest $\left(08^{\circ} 27^{\prime} 14^{\prime \prime} S, 38^{\circ} 39^{\prime} 10^{\prime \prime E}\right)$.
Diagnosis. - Medium sized Grammomys (HB: 79$107 \mathrm{~mm}$ ) with tail length representing 147 and $156 \%$ of HB, HF: 23-23.5 mm. It is characterized by a yellow-light brown dorsal short pelage and a cream-white ventral one. The tail is yellow and does not display a terminal tuft but has some pale scattered longer hairs (2-3 mm long) at the extremity. There is no subauricular tuft visible. The skull length is $24.88-29.65 \mathrm{~mm}$, nasal length relatively short $(7.84-11.09 \mathrm{~mm})$ and braincase round and wide delimitated by rectilinear $V$-shaped fronto-parietal crests. There is a moderate development of stephanodonty in the molars. On the upper M1, $\mathrm{t} 1$ linked to $\mathrm{t} 2$, presence of a stephanodont crest with $\mathrm{t} 7$ not visible on the $t 4$. The t 9 and $t 8$ are round and related by a little oblique crest and there is a well-developped posterior cingulum. On the labial side of the lower molars there is a continuous 
TABLE 10. - External Grammomys Thomas, 1915 standard measurements (in millimeters) for the different type specimens of the genus. On morphological grounds, G. surdaster Thomas \& Wroughton, 1908, G. s. elgonis (Thomas, 1910) and G. s. insignis (Thomas, 1911) have been synonymized with G. dolichurus (Smuts, 1832) by Musser \& Carleton (2005), who ignored G. surdaster lutosus Dollman, 1911. The name G. rutilans Peters, 1876 from Gabon is not available and was changed into G. poensis (Eisentraut, 1965) but the type of G. rutilans centralis (Dollman, 1914) from Congo exists in BMNH and the name of the taxon has been synonymized with G. kuru (Musser \& Carleton 2005). No measurements were available on the label but the tail of G. kuru holotype BMNH 7.7.8.176 is smaller than HB. The type specimen of G. usambarae (Matschie, 1915) from Amani (Tanzania) was identified by Dieterlen (pers. comm.) as G. dolichurus. The so-called dolichurus series consists of 3 individuals mentioned in Hutterer \& Dieterlen (1984) as similar to the true dolichurus. We used the Osgood (1910) description of the G. ibeanus Osgood, 1910 and G. surdaster polionops (Osgood, 1910) holotypes and a mean value from the type series. Abbreviations: see Material and methods.

\begin{tabular}{|c|c|c|c|c|c|c|c|c|}
\hline Species & Status & Specimen & Country & Value & HB & TL & HF & E \\
\hline G. selousi n. sp. & $\mathrm{HT}$ & $\begin{array}{l}\text { MNHN-CG2007- } \\
1231\end{array}$ & Tanzania & & 107 & 167 & 23.5 & 17.5 \\
\hline G. selousi n. sp. & PT & $\begin{array}{l}\text { MNHN-CG2007- } \\
1252\end{array}$ & Tanzania & & 79.5 & 117.5 & 23 & 15 \\
\hline $\begin{array}{l}\text { G. macmillani } \\
\text { (Wroughton, 1907) }\end{array}$ & $\mathrm{T}$ & BMNH 6.11.1.38 & Ethiopia & & 102 & 160 & 21 & 15 \\
\hline $\begin{array}{l}\text { G. cometes } \\
\text { (Thomas \& } \\
\text { Wroughton, 1908) }\end{array}$ & $\mathrm{T}$ & BMNH 6.11.8.115 & Mozambique & & 124 & 195 & 24 & 20 \\
\hline $\begin{array}{l}\text { G. aridulus Thomas \& } \\
\text { Hinton, } 1923\end{array}$ & $\mathrm{~T}$ & BMNH 23.1.1.324 & Sudan & & 115 & 175 & 24 & 18 \\
\hline G. rutilans centralis & $\mathrm{T}$ & BMNH 14.2.11.24 & Congo & & 135 & 180 & 24 & 16 \\
\hline G. surdaster surdaster & $\mathrm{T}$ & BMNH 93.5.2.27 & Malawi & & & & 22 & 18 \\
\hline G. surdaster elgonis & $\mathrm{T}$ & BMNH 10.4.1.189 & Uganda & & 115 & 165 & 23 & 17 \\
\hline G. surdaster insignis & $\mathrm{T}$ & BMNH 10.4.1.186 & Uganda & & 120 & 185 & 25 & 22 \\
\hline $\begin{array}{l}\text { G. dryas Thomas, } \\
1907\end{array}$ & $\mathrm{~T}$ & BMNH 6.7.1.136 & Uganda & & 118 & 185 & 24.5 & 19 \\
\hline $\begin{array}{l}\text { G. gigas Dollman, } \\
1911\end{array}$ & $\mathrm{~T}$ & BMNH 11.4.7.93 & Kenya & & 132 & 201 & 26.5 & 19 \\
\hline G. surdaster lutosus & $\mathrm{T}$ & BMNH 12.7.1.265 & Kenya & & 118 & 198 & 24 & 22 \\
\hline $\begin{array}{l}\text { G. butingi Thomas, } \\
1911\end{array}$ & $\mathrm{~T}$ & BMNH 11.7.28.27 & Liberia & & 108 & 170 & 23.5 & 15 \\
\hline $\begin{array}{l}\text { G. caniceps Hutterer } \\
\text { \& Dieterlen, } 1984\end{array}$ & $\mathrm{~T}$ & ZFMK84 & Kenya & & 104 & 153 & 21.5 & 17.1 \\
\hline G. usambarae & $\mathrm{T}$ & ZMB20571 & Tanzania & & (77) & 130 & 21 & (8) \\
\hline G. poensis & $\mathrm{T}$ & ZFMK63668 & Equatorial Guinea & & 139 & 195 & 26 & 17 \\
\hline $\begin{array}{l}\text { G. minnae Hutterer \& } \\
\text { Dieterlen, } 1984\end{array}$ & $\mathrm{~T}$ & SMNS24118 & Ethiopia & & 110 & 173 & 23 & 18 \\
\hline G. ibeanus & $\mathrm{T}$ & FMNH 17096 & Kenya & & 136 & 193 & 26 & 21 \\
\hline G. ibeanus & TS & FMNH type series & Kenya & mean $(\mathrm{N}=8)$ & 121 & 184 & 25.3 & 20.7 \\
\hline G. d. dolichurus & & After Roberts (1951) & RSA Cape Region & $\begin{array}{l}\min -\max \\
\operatorname{mean}(\mathrm{N}=8) \\
\min -\max \end{array}$ & $\begin{array}{l}109-136 \\
122 \\
103-124\end{array}$ & $\begin{array}{l}174-204 \\
173 \\
151-178\end{array}$ & $\begin{array}{c}24-26 \\
24\end{array}$ & $\begin{array}{c}19-22 \\
18\end{array}$ \\
\hline G. dolichurus series & & SMNS, ZFMK & Tanzania & mean $(\mathrm{N}=3)$ & 111.7 & 150.3 & 23.7 & 16 \\
\hline
\end{tabular}

cingular margin with small cusplets development. The upper M3 is small and round with well marked T1. It is characterized by the following chromosome formula: $2 \mathrm{n}=49-50, \mathrm{FNa}=56$.

At equivalent age teeth wear classes 3 to 5 , it is different from $G$. dolichurus, G. caniceps, G. macmillani in being larger (skull and external dimensions). It is smaller than G. cometes, G. poensis, G. gigas, G. dryas, G. ibeanus, $G$. brevirostris. It has about the same body and tail length proportions as $G$. aridulus but with a larger ear and HF.
It is about the same size as $G$. butingi and $G$. minnae type specimens. It differs from $G$. minnae, $G$. caniceps, $G$. dolichurus s.l. and all other karyotyped specimens by its chromosome formula. G. ibeanus is larger, has a brown dull pelage with long hairs, the tail tuft is more visible and at the last third of the tail one finds long brown hairs (4-5 mm long). Grammomys ibeanus displays a longer nasal and less globular braincase; its frontoparietal crests are not rectilinear. Grammomys brevirostris has an isolated $\mathrm{t} 1$ on the upper M1 and a longer rostrum and masseteric plate. 


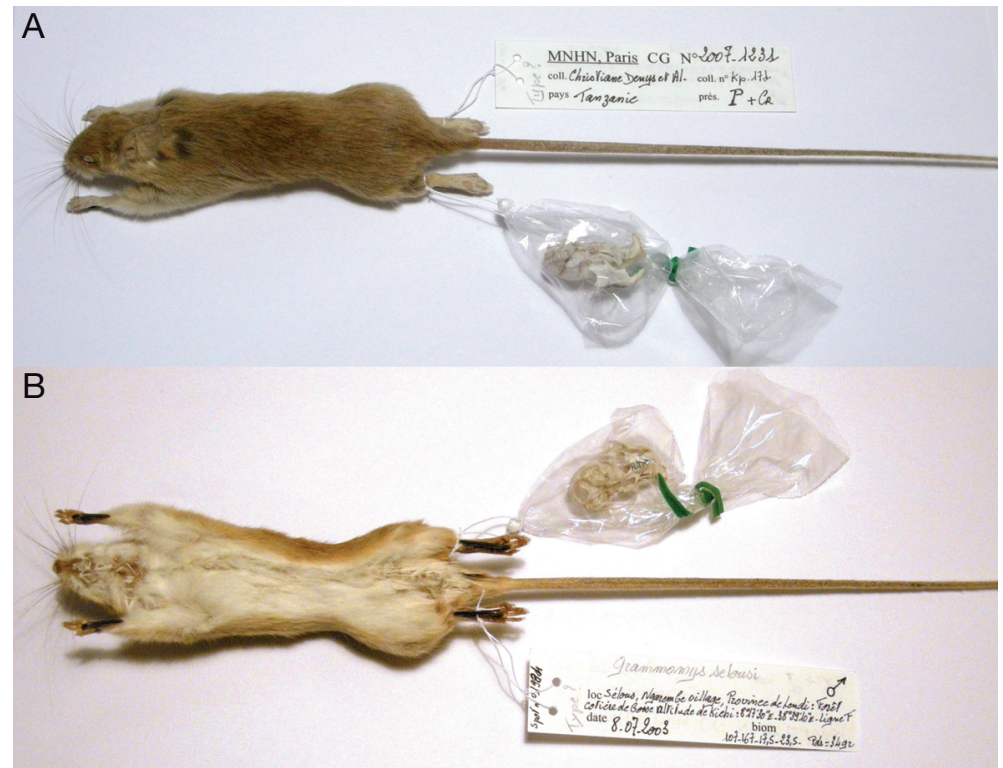

FIG. 9. - A, external dorsal and B, ventral views of MNHN-CG2007-1231, Grammomys selousi n. sp. holotype.
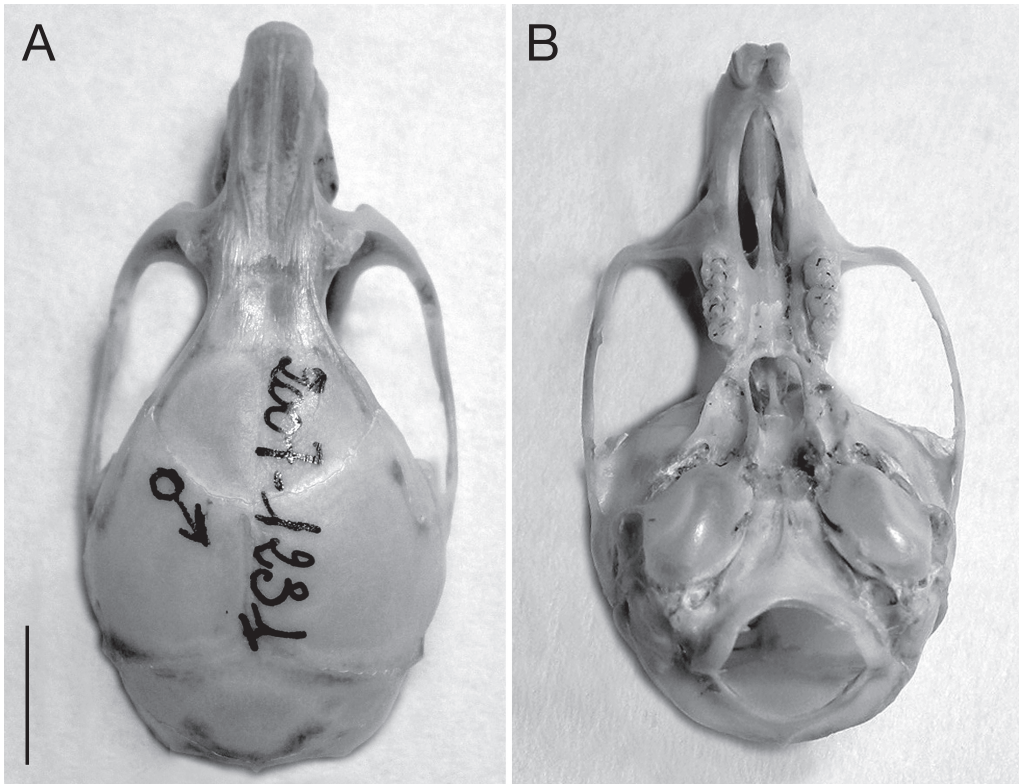

FIG. 10. - A, dorsal and B, ventral views of Grammomys selousi n. sp. holotype skull (MNHN-CG2007-1231). Scale bar: 5 mm. 


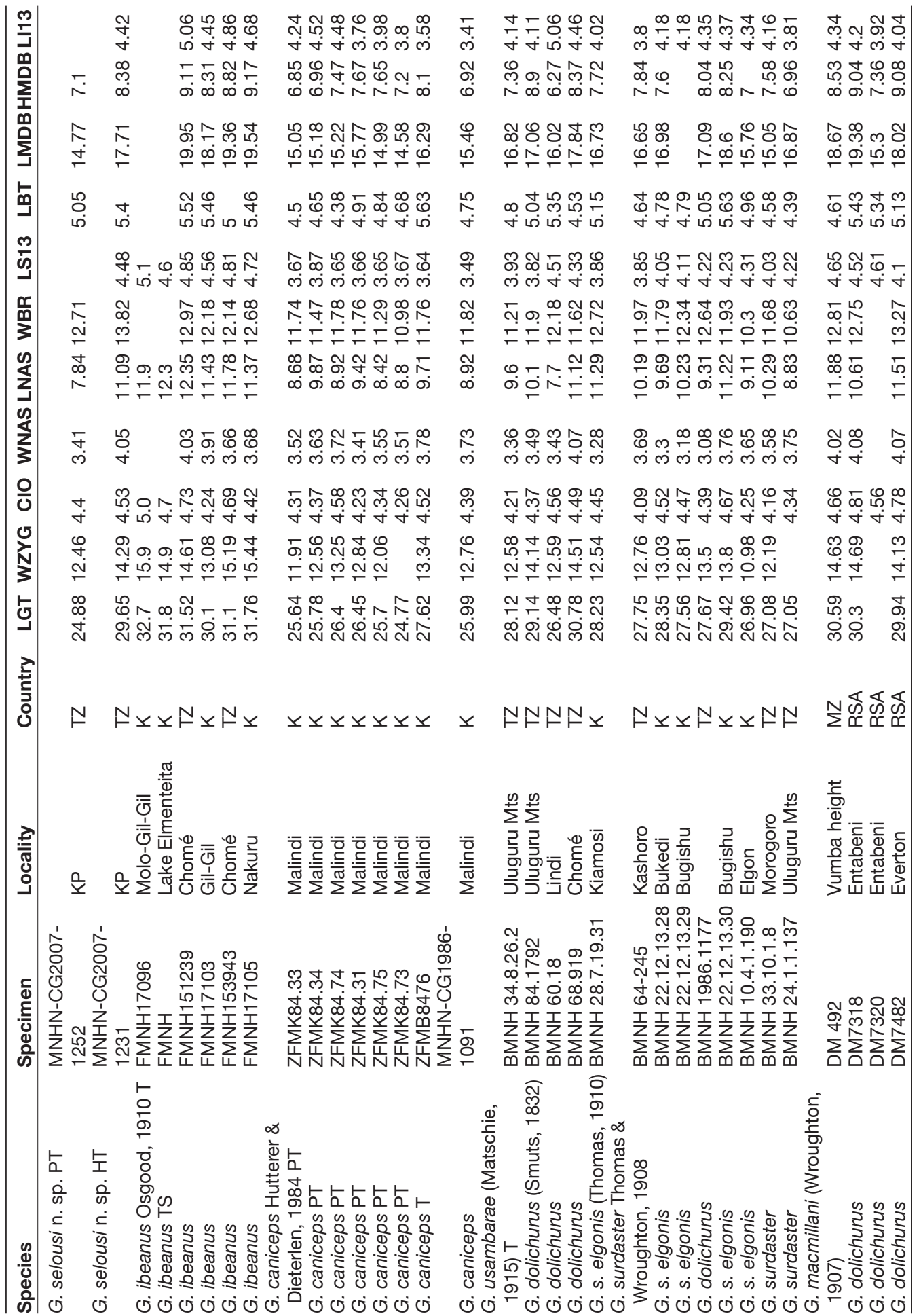




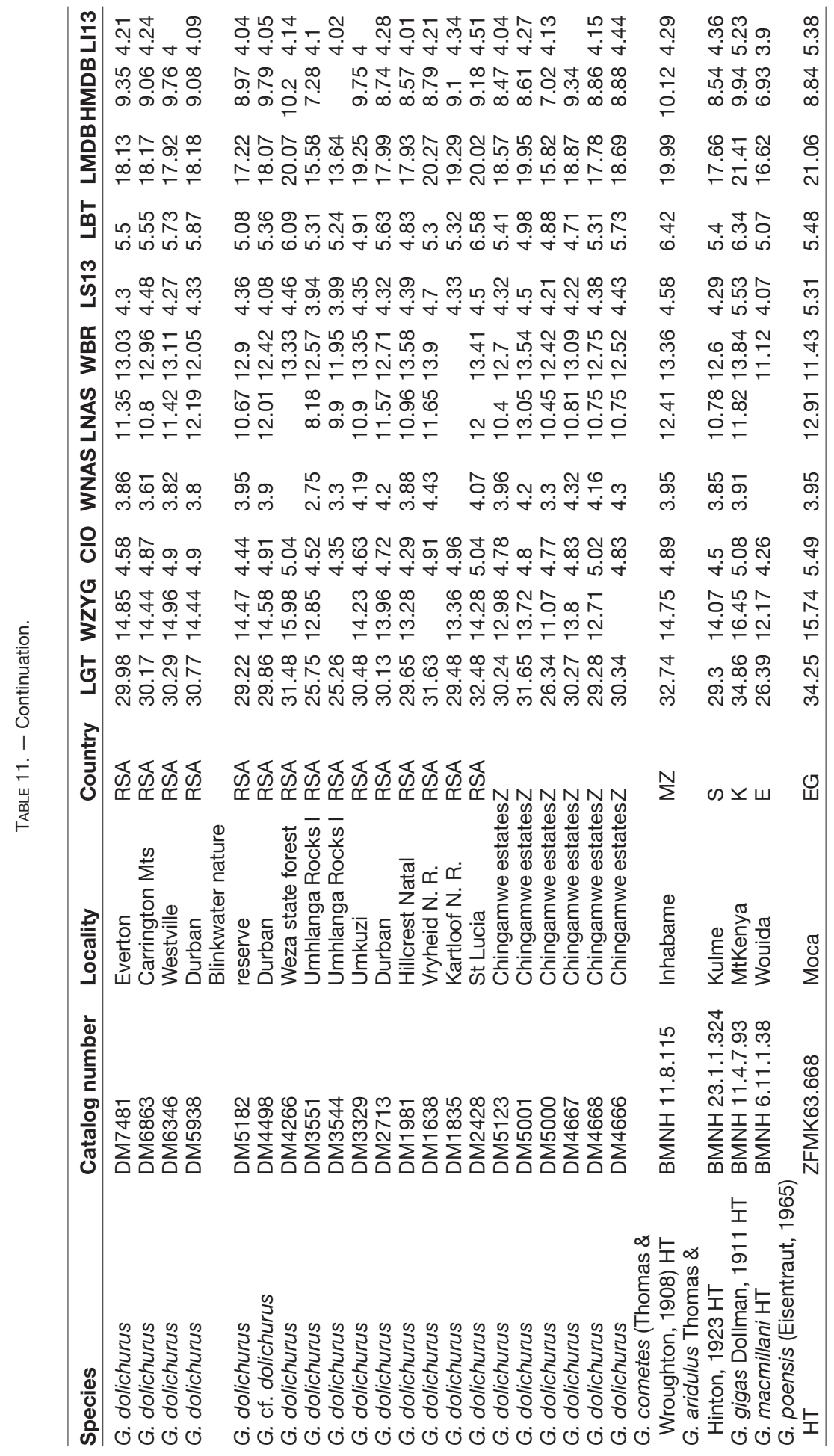


DESCRIPTION

Yellowish-brown pelage on the back with grey bases (about 9-10 mm over middle rump). The yellowbrown colour is less intense on the flanks, which are lighter. There is a marked demarcation line with the nearly pure white belly. The upper part of the head has the same colour as the back, and the mouth region is white like the belly. Tail notably longer than head and body (147-156\%), yellow to light-brown in colour terminated at the tip by longer hairs of the same colour (2-3 mm) (Fig. 9). There are no hairs on the tail at the base, small hairs appear about the middle of the tail and increase progressively in length till its end but they remain scarce. Top of fore and hind feet of the same colour pale yellow white turning to pale brown on the underside, ungual tufts white. Hind feet short but wide. Digit 5 longer than 1, plantar surfaces naked, with 6 small cushion pads on the hindfoot.

The skull shows the Grammomys microdont tooth pattern (Fig. 10). The braincase is rounded and inflated in the parietal region, the interorbital region is marked but not very narrow, the rostrum is quite short and narrow. There are supra-orbital ridges starting in the interorbital constriction region on the border of the orbital foramen at the level of the naso-frontal suture and ending in the middle of the parietal bones just above the end of the zygomatic arch. In lateral view, the braincase is convex especially in the parietal region and the occipital region where it makes a re-entrant angle with the inter-parietal plan. The tympanic bullae are not inflated quite proportional to the small size of the skull. There are long and narrow incisive foramen ending at the anterior cingulum level of the first molar. The very small posterior palatal foramina are situated at the level of the first lobe of second molar. The mesopterygoid fossa is narrow and long, its anterior border rounded. The pterygoid fossa is shallow with no obvious ventral part of foramen ovale visible. The pterygoid bridge is low and the foramen ovale small. There is a small round opening of the alisphenoid canal. The middle lacerate foramen is small and narrow; the carotid canal is long and thin (more than $2 \mathrm{~mm}$ ). In lateral view the mastoid part of the tympanic bullae is slightly inflated. The temporal ridges are well marked and vertical. The mandible is short.
Incisors are yellow without any striation and opistodont. The molars display moderately developed stephanodont crests on the $\mathrm{t} 1$ and $\mathrm{t} 3$. The $\mathrm{t} 4$ cusp of the upper M12/ is prolongated by a crest not related to the $t 8$ but there is no visible $\mathrm{t} 7$ on it. On the upper M12/ the $\mathrm{t} 8$ is high and a posterior cingulum crest is visible, the $\mathrm{t} 9$ is small and very round and situated very anteriorly, close to the t6 and there is a little oblique crest relating the $\mathrm{t} 9$ to the $t 8$. From the $t 8$ reaching the labial border of the $\mathrm{M} 12 /$ one can see a posterior cingulum crest. The lower molars display a continuous cingular crest on the labial margin of the lower $\mathrm{M} / 1$. The $\mathrm{Cp}$ is large on the $\mathrm{M} / 12$. Some stephanodont crests are seen on the second lobe of the M/12 and the prelobe of the lower M/1 harbours a well-developed tma. The M3/3 are relatively small and have a round aspect (Fig. 11). The upper M3/ displays a $\mathrm{t} 1$ and a $\mathrm{t} 3$. There is no antero-labial cingulum on the lower $\mathrm{M} / 3$.

The adult specimen of the new species is smaller than $G$. gigas, G. dryas and G. cometes, G. kempi, G. ibeanus from Kenya, Sudan and RSA (Tables 10, 11 ). The adult specimen fits within size range of G. dolichurus, G. macmillani from Tanzania and Sudan but has a longer hindfoot. It has broadly the same size than $G$. aridulus which is a very old specimen (dental wear stage 6). It also fits within the size variation of $G$. dolichurus from Natal in RSA. But, a comparison with the type specimen of $G$. dolichurus from BMNH shows that our specimen has a more globular skull and a very short nasal (Tables 10, 11). The hindfoot length of $G$. selousi $n$. sp. enters into the variability of $G$. dolichurus, $G$. aridulus and $G$. minnae, as assessed by Hutterer \& Dieterlen (1984), but is notably smaller compared to the types of $G$. poensis, $G$. gigas and $G$. ibeanus. The holotypes of $G$. cometes and $G$. gigas, are old adults characterized by advanced wear stages of the molars but they display much larger upper molar rows than the new Kingu Pira species. The type specimens of $G$. macmillani, G. surdaster and $G$. dryas have much smaller molars and the type specimens of $G$. surdaster display the smallest M3/3. The last three species are also characterized by a relatively moderate stephanodonty. The new Selous Grammomys also differs from $G$. brevirostris by its larger skull, longer rostrum, and like other east and south African species by the $\mathrm{t} 1$ not isolated from $\mathrm{t} 2$. 
A

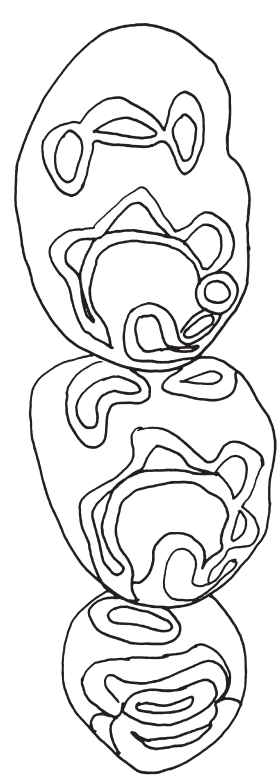

$\mathrm{E}$

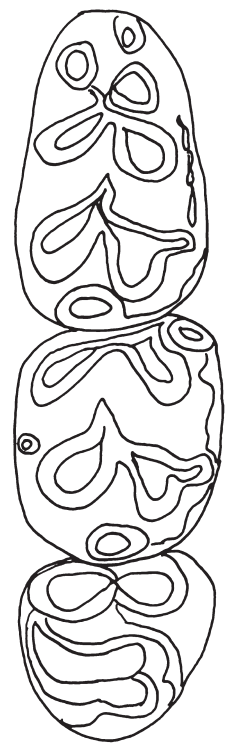

B

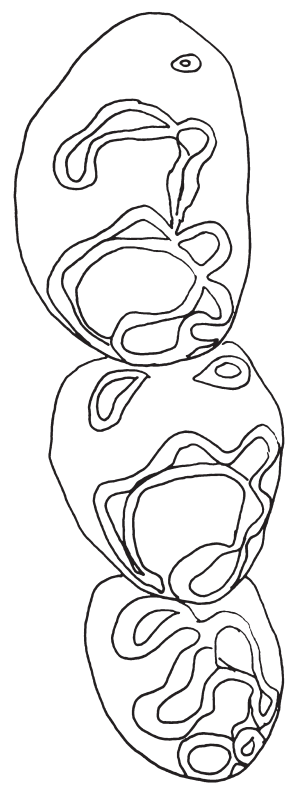

$\mathrm{F}$

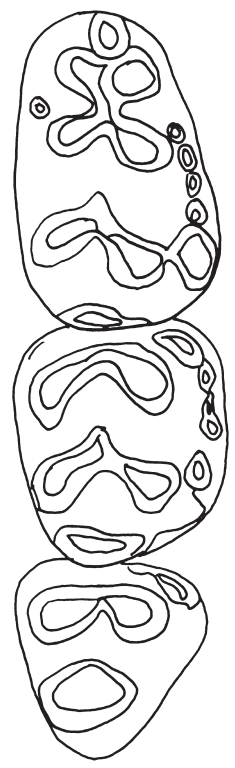

C
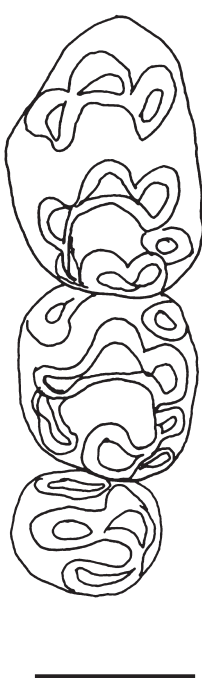

G

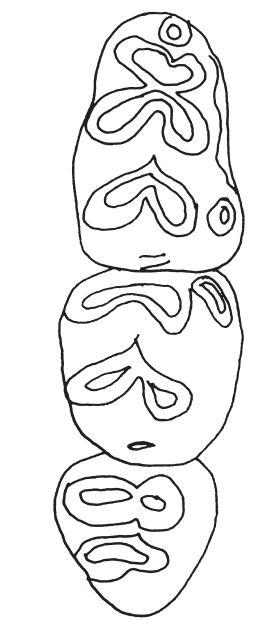

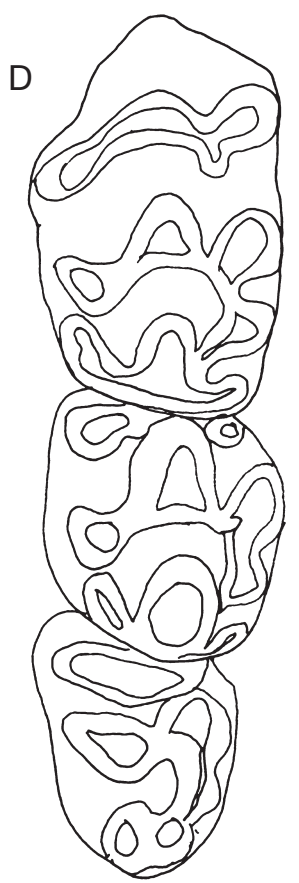

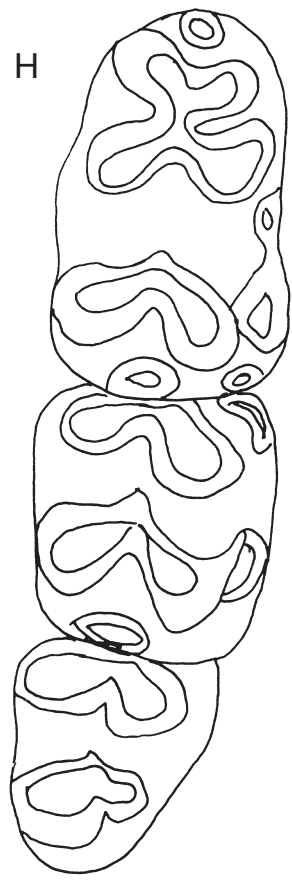

FIG. 11. - A-D, upper left and E-H, lower right molar rows of Grammomys species (A, E) G. selousi n. sp. holotype; B, F, G. ibeanus Osgood, 1910 (FMNH 17103), Gil-Gil, Kenya; C, G, G. caniceps Hutterer \& Dieterlen, 1984 holotype; D, H, G. poensis (Eisentraut, 1965) holotype. Scale bars: $1 \mathrm{~mm}$. 
TABLE 12. - Grammomys Thomas, 1915 species karyological characteristics. Abbreviations: see Material and methods.

\begin{tabular}{|c|c|c|c|c|c|c|c|}
\hline Taxon/specimen & $2 n$ & $\mathrm{FNa}$ & $\mathrm{MC}+\mathrm{SM}$ & ST & AC & Origin & Authors \\
\hline $\begin{array}{l}\text { G. selousi n. sp. MNHN-CG2007- } \\
1231 \text { MNHN-CG2007-1252 }\end{array}$ & $49-50$ & 56 & $?$ & $?$ & $?$ & $\mathrm{KP}$ & This work \\
\hline G. dolichurus (Smuts, 1832) & 52 & 66 & 7 & & 19 & RSA & Petter \& Tranier 1975 \\
\hline G. dolichurus & 52 & 66 & & & & RSA & Matthey 1971 \\
\hline G. dolichurus & 52 & & & & & RSA & $\begin{array}{l}\text { Dippenaar et al. } 1984 \\
\text { Kryštufek et al. } 2008\end{array}$ \\
\hline G. butingi Thomas, 1911 & 52 & $\mathrm{FN}=66$ & 7 & & 19 & Ivory Co & Petter \& Tranier 1975 \\
\hline $\begin{array}{l}\text { G. cometes (Thomas \& Wroughton, } \\
\text { 1908) }\end{array}$ & 52 & & & & $x$ & RSA & Kryštufek et al. 2008 \\
\hline G. dolichurus & $54-61$ & $70-75$ & & & & Somalia & Roche et al.1984 \\
\hline G. sp. butingi & 20 & 31 & 7 & 2 & & Tanzania & Corti et al. 2005 \\
\hline $\begin{array}{l}\text { G. ex gazellae macmillani } \\
\text { (Wroughton, 1907) }\end{array}$ & $68-76$ & $>82$ & $>7$ & & $>20$ & CAR & Petter \& Tranier 1975 \\
\hline Grammomys sp.? & 44 & & & & & RSA & Dippenaar et al. 1984 \\
\hline Grammomys sp. & 27 & 39 & & & & N Tanzania & Fadda et al. 2001 \\
\hline G. minnae Hutterer \& Dieterlen, 1984 & 32 & 64 & 15 & 1 & & Ethiopia & Olert et al. 1978 \\
\hline $\begin{array}{l}\text { G. poensis (ex rutilans) (Eisentraut, } \\
\text { 1965) }\end{array}$ & 36 & $\mathrm{FN}=50$ & & & & Ivory Coast & Tranier \& Dosso 1979 \\
\hline $\begin{array}{l}\text { G. caniceps Hutterer \& Dieterlen, } \\
1984\end{array}$ & 56 & 78 & 11 & & 17 & Kenya, Malindi & $\begin{array}{l}\text { Hutterer \& Dieterlen } \\
1984\end{array}$ \\
\hline G. dolichurus? (ex surdaster) & $\begin{array}{l}52 \\
52\end{array}$ & $\mathrm{FN}=66 ?$ & $6+1$ & & 19 & Katanga & Matthey 1971 \\
\hline $\begin{array}{l}\text { G. kuru (ex rutilans) (Musser \& } \\
\text { Carleton, 2005) }\end{array}$ & 50 & 50 & & & & DRC & Matthey 1963 \\
\hline $\begin{array}{l}\text { G. sp. surdaster Thomas \& } \\
\text { Wroughton, } 1908\end{array}$ & $50-51$ & 61 & & & & Zambia & Corti et al. 2005 \\
\hline G. sp. surdaster & 42 & 64 & 12 & & 8 & Tanzania & Corti et al. 2005 \\
\hline
\end{tabular}

External and skull quantitative comparisons

The PCA performed upon the four standard external measurements for all the holotypes available (after Table 10) displays, on the graph of axes 1 and $2,99.11 \%$ of the variability. Axis 1 is positively correlated with all the variables and represents a size axis. Thus the PCA graph shows the relative intermediate size of G. selousi n. sp. (Fig. 12), which is larger than $G$. caniceps and $G$. macmillani and smaller than $G$. poensis, G. ibeanus, G. gigas, G. dryas, Grammomys kempi, G. cometes and G. rutilans holotypes. G. selousi n. sp. is here close to G. aridulus, G. macmillani, G. minnae and G. butingi. Compared to the latter holotypes, $G$. selousi n. sp. is at wear stage 4, while $G$. aridulus and $G$. butingi display very worn molars (stage 6), G. macmillani holotype is at wear stage 3 and the $G$. minnae one is at wear stage 4 . The scatter plots display the same pattern and show the proximity of $G$. selousi n. sp. with G. butingi (Fig. 13).
We performed also a PCA on 11 skull measurements based upon 50 individuals only (after data in Table 11). The graph of axis 1 and 2 displays $89.51 \%$ of the total variability. Axis 1 is explained and correlated positively with LGT, LMDB, LNAS, HMDB, WZYG while axis 2 is explained by WBR and LS13, LI13. We observe here the relatively wide variability of $G$. dolichurus from RSA while $G$. selousi n. sp. is again in the middle of the graph and close to the type specimen of $G$. aridulus. The holotypes of $G$. gigas, $G$. cometes and $G$. poensis (the largest) are opposed along axis 1 to the smallest G. caniceps (Fig. 14). In order to include some of the damaged holotypes to the analyses, we used also bivariate analyses and the scatter plot of LGT versus WZYG confirms the large size of $G$. ibeanus, the small size of $G$. macmillani as well as the very wide skull of G. brevirostris (Fig. 15A). By looking at the molar row length versus skull length we confirm the same result and do not see any microdonty trend 


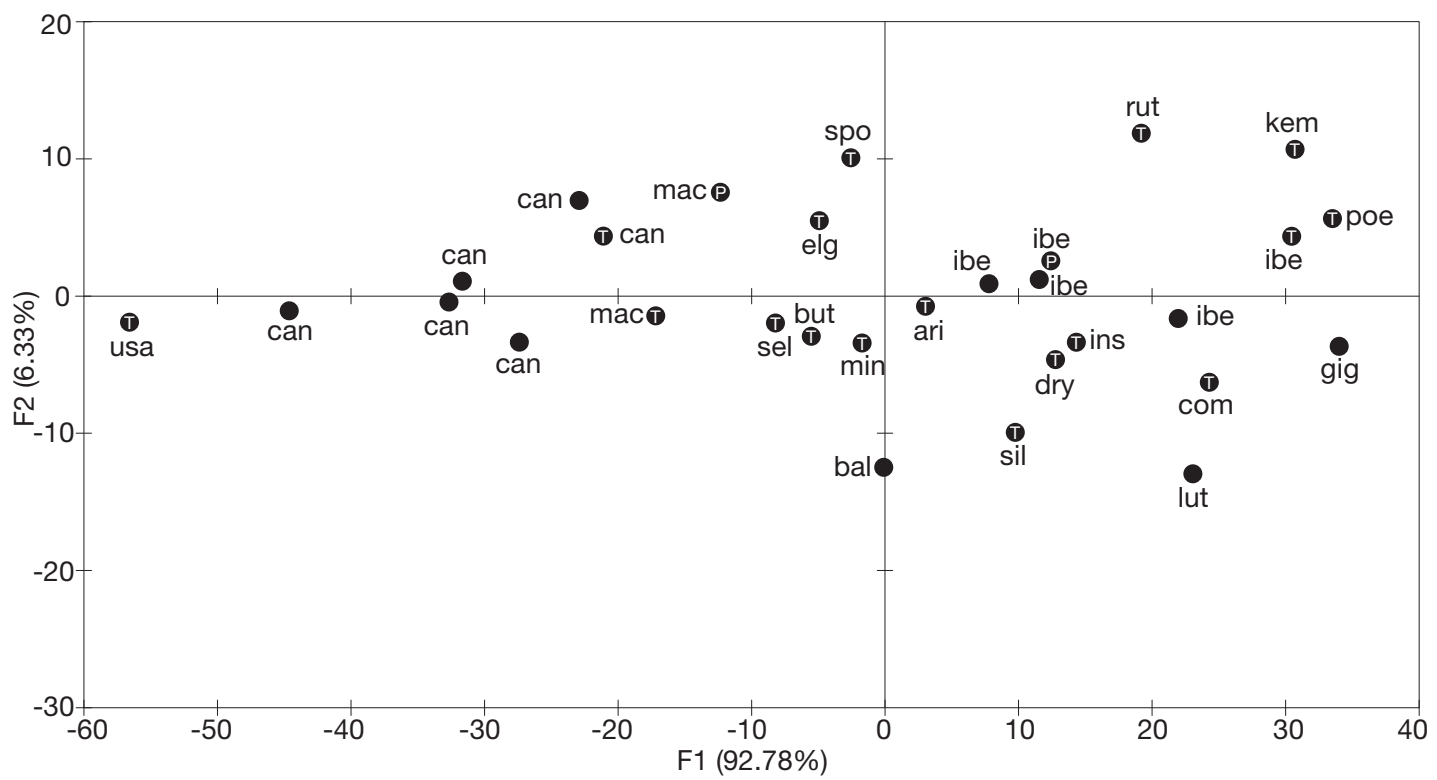

FIG. 12. - PCA performed on four external standard measurements of Grammomys Thomas, 1915, with comparisons across the different BMNH, ZFMK type specimens. Axes F1 × F2: 99.11\%. Abbreviations: see Material and methods. Symbols: P, paratype; $\mathbf{T}$, holotype.

(reduction of LS13 length) among the species we compared (Fig. 15B).

\section{Karyological description}

The new species is characterized by its peculiar chromosome formula and morphology. Two specimens of our study possess 49 and 50 chromosomes respectively and similar $\mathrm{FNa}=56$ (Fig. 16). The variability of diploid numbers results from Robertsonian polymorphism well-known in mammals and especially in rodents and previously described for Somalian Grammomys (Roche et al. 1984). Although karyotypically the Kingu Pira individuals display some affinities with the specimens called $G$. kuru (ex rutilans) by Matthey (1963) from Pointe Noire (CDR), they are clearly different from all earlier descriptions of karyotypes (Table 12) in Grammomys. Notably, this karyotype is strongly different from those of $G$. dolichurus from RSA, G. butingi and G. poensis from Ivory Coast, G. gazellae from CAR, G. minnae of Ethiopia and from that of the Grammomys sp. described in northern Tanzania by Fadda et al. (2001). There still is some debate in Grammomys taxonomy (Corti et al. 2005).
According to Musser \& Carleton (2005), G. poensis (ex rutilans), whose type specimen comes from Bioko island (Equatorial Guinea) and was found in Ivory Coast by Tranier \& Dosso (1979), is characterized by $2 \mathrm{n}=36$ chromosomes. This chromosome formula is different from that of the Congo specimen from Pointe Noire, which would better be attributed to G. macmillani sensu Musser \& Carleton (2005). Therefore, the $G$. poensis (ex rutilans) sensu Musser \& Carleton (2005) is probably a complex of sibling species whose revision is urgently needed. When looking at all the karyotypes formulae, we see that sibling species may also exist among $G$. dolichurus, $G$. surdaster and $G$. butingi complexes.

There is no available karyotype for $G$. aridulus which comes from Darfur region (Sudan) but the latter is greyish brown in colour and proportionaly has a long tail (152\%). Because the holotype is at wear stage 6, we infer that the repeated proximity with $G$. selousi n. sp., which is at stage 4, is not reflecting the mean size of $G$. aridulus populations which must be smaller than $G$. selousi n. sp. Moreover, there is a considerable geographic distance between Kulmé and Kingu Pira 
A

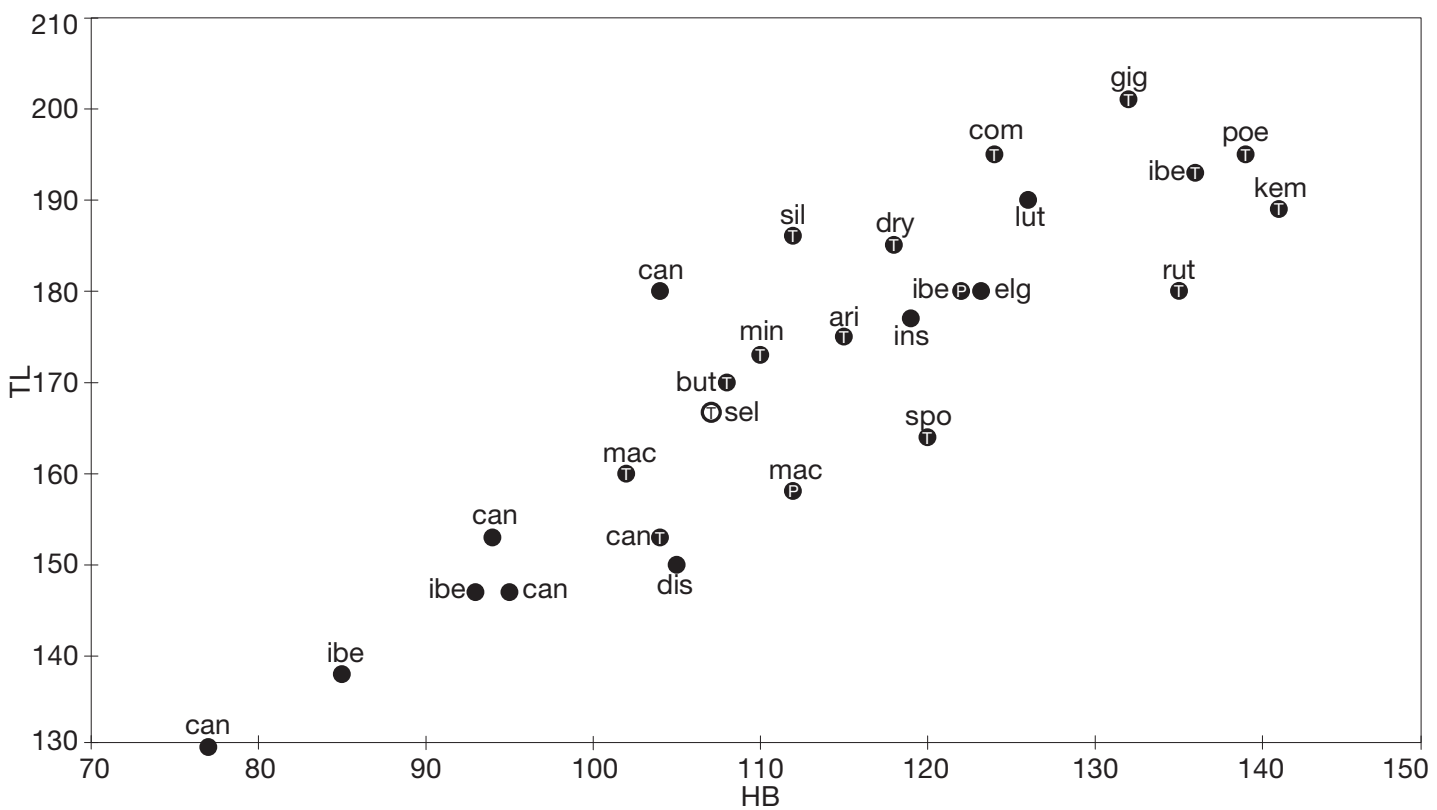

$\mathrm{B}$

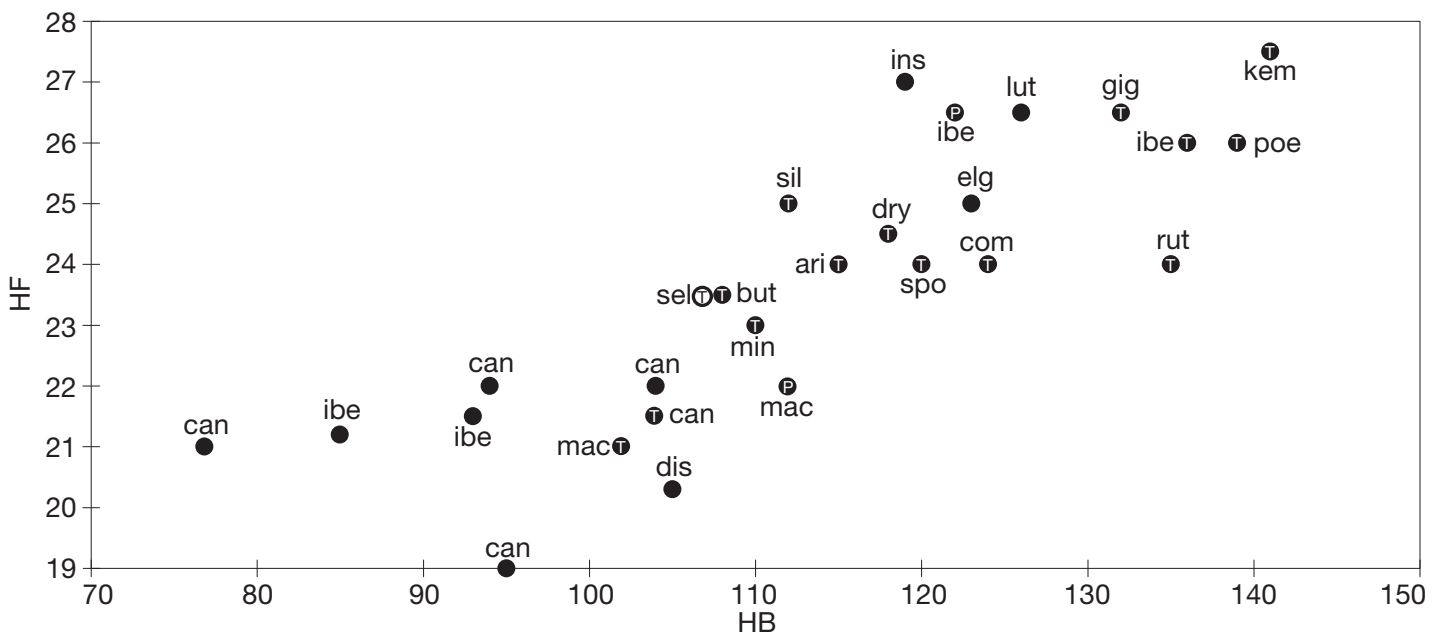

FIG. 13. - Scatterplots upon external measurements (in millimetres) for different Grammomys Thomas, 1915 type specimens: A, HB versus TL; B, HB versus HF. Abbreviations: see Material and methods. Symbols: P, paratype; T, holotype.

(about $3000 \mathrm{~km}$ ) and both places are respectively situated in different ecoregions (sudanian savanna for $G$. aridulus versus Miombo woodland for G. selousi n. sp.). Similarly, G. brevirostris is not known by karyotypes but its wider skull and shorter rostrum indicate that it is very different from $G$. selousi n. sp.
In conclusion, because our new specimens display important morphological and size differences with holotypes specimens and chromosomal ones of other Tanzanian forms, we propose to attribute our Selous individuals to a new Grammomys species pending further molecular and cytogenetical analyses in the genus. 


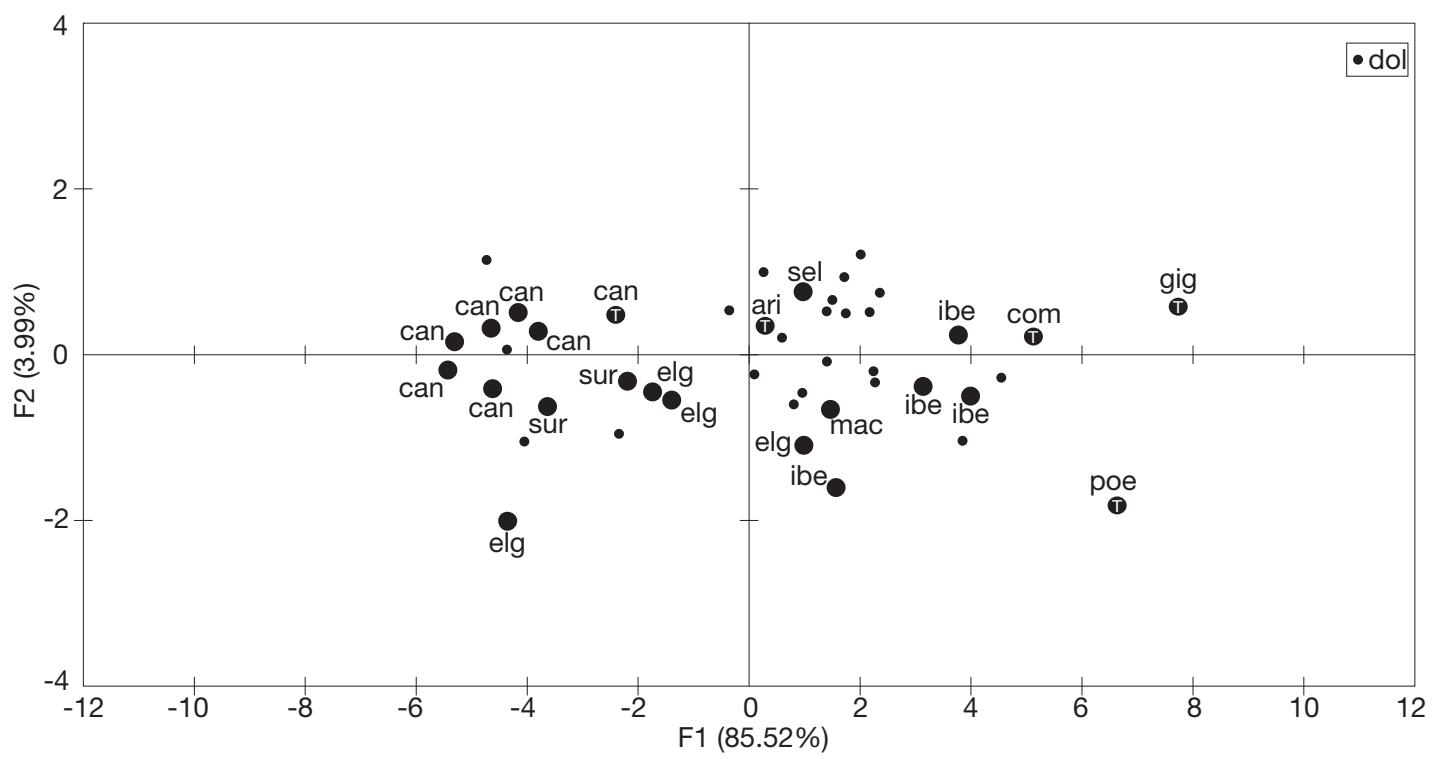

FIG. 14. - PCA performed on 11 skull measurements and 50 individuals of Grammomys Thomas, 1915. Axes F1 × F2: $89.51 \%$. Abbreviations: see Material and methods. Symbol: T, holotype.

Genus Mus Linnaeus, 1758

According to Musser \& Carleton (2005), M. neavei Thomas, 1910 (group sorella) and Mus minutoides Smith, 1834 occur in south Tanzania. Mus minutoides is found in southern and eastern regions of South Africa from Mozambique (south of the Zambezi river) to the Cape and according to Musser \& Carleton (2005) its northern limits are unkown. Previous cytogenetical works have already focused the important genetic variability in this group which is subjected to Robertsonian fusions (Matthey 1966, 1967, 1970a, b; Jotterand-Bellomo 1984, 1986; Veyrunes et al. 2004).

\section{Mus (Nannomys) minutoides Smith, 1834}

Leggada minutoides Smith, 1834: 157.

One individual was trapped by hand (out of any trap line) close to the village, two others in Lines $\mathrm{C}$ and D. They belong to a very small sized Mus species and show a brown back and white belly and a relatively long tail which places them into the
$M$. minutoides or $M$. tenellus group in Kingdon's (1974) key to east African Mus. The upper M1/ has a very elongated prelobe and the upper M3/ is very reduced. In order to get more morphological criteria of discrimination we have performed skull measurements on karyotyped series of both species and some morphological analysis. The three KP specimens fit well with the karyotyped $M$. minutoides specimens from Matthey for their sizes, except the HF length, which is smaller, and under the minimum value of the karyotyped sample. Skull dimensions fit well into the $M$. minutoides variability (Table 13 ).

From a chromosomal point of view, pygmy mice have a strong variability in their diploid and fundamental numbers as described by Matthey (1970a, b), Aniskin et al. (1998), Veyrunes et al. (2004) and Kan Kouassi et al. (2008). A molecular analysis (Verhuynes et al. 2005) has shown that the KP Mus (Nannomys) fits well within the $M$. minutoides group together with Guinean and South African specimens and this group diverges from $M$. musculoides (Kan Kouassi et al. 2008). The variation of diploid numbers observed here in KP results from $\mathrm{Rb}$ polymorphism often occurring in the species 
TABLE 13. - External and skull measurements (in millimetres) of Mus (Nannomys) Smith, 1834 karyotyped specimens. Specimens of M. minutoides Smith, 1834 belong to the karyotyped series of Matthey $(1966,1967)$ whose vouchers are in the MNHN collections. Abbreviations: NMI, number of measurements taken in the sample; others, see Material and methods.

\begin{tabular}{|c|c|c|c|c|c|c|c|c|c|c|c|c|c|}
\hline Taxon/specimen & HB & TL & E & HF & LGT & WZYG & LNAS & WNAS & CIO WBR & LBT LS13 & 3 LMDB & B HMDB & 3 LI13 \\
\hline MNHN-CG2007-1250 & 40 & 34 & 4.5 & 12 & & & & & & & & & \\
\hline $2007-1207$ & 753 & 40.5 & 9.5 & 12.5 & 17.71 & 8.13 & 6.58 & 2.2 & 3.148 .02 & 3.553 .07 & 10.49 & & 2.42 \\
\hline MNHN-CG2007-1061 & 155.5 & 41 & 9.5 & 11.59 & 18.46 & 8.57 & 6.94 & 2.54 & 3.278 .41 & 3.523 .19 & 11.33 & 4.52 & 2.6 \\
\hline \multicolumn{14}{|c|}{ M. minutoides $\mathrm{E}$ \& S Africa Matthey } \\
\hline Mean & 54.32 & 45.16 & 10.1 & 13.8 & 17.9 & 8.55 & 6.78 & 2.52 & 3.288 .14 & 3.533 .14 & 11.43 & 4.8 & 2.67 \\
\hline NMI & 28 & 25 & 26 & 25 & 22 & 17 & 23 & 23 & 23 & $22 \quad 24$ & 22 & 20 & 24 \\
\hline i & 45 & 24 & 8 & 13 & 16.27 & 7.86 & 5.59 & 2.16 & 2.967 .61 & 3.032 .86 & 10.34 & 3.69 & 2.1 \\
\hline Maxi & 63 & 56 & 12 & 15 & 19.57 & 9.07 & 7.96 & 2.96 & 3.678 .9 & 4.023 .54 & 12.84 & 5.34 & 3.31 \\
\hline SD & 4.9 & 5.8 & 0.93 & 0.57 & 0.95 & 0.38 & 0.61 & 0.19 & 0.190 .30 & 0.210 .19 & 0.71 & 0.38 & 0.31 \\
\hline
\end{tabular}

TABLE 14. - Chromosomal data for Mus (Nannomys) Smith, 1834 of the M. minutoides Smith, 1834-M. musculoides Temminck, 1853 complex species. Abbreviations: see Material and methods.

\begin{tabular}{lccll}
\hline Taxon/specimen & 2n & FNa & Origin & Authors \\
\hline MNHN-CG2007-1061 & 34 & 32 & Tanzania & this work \\
MNHN-CG2007-1250 & 35 & 32 & Tanzania & this work \\
M. minutoides & 18 & 35 & South Africa & Veyrunes et al. 2004 \\
M. minutoides & 34 & 36 & South Africa & Veyrunes et al. 2004 \\
M. minutoides & 18 & 36 & South Africa & Veyrunes et al. 2004 \\
M. minutoides & 34 & 36 & Bantou, Guinea & Kan Kouassi et al. 2008 \\
M. musculoides & 19 & 36 & Djoliba, Mali & Veyrunes et al. 2004 \\
M. musculoides & $18-19$ & 36 & Samaya, Mali & Veyrunes et al. 2004 \\
M. minutoides/ M. musculoides & $33-36$ & 36 & Ivory Coast & Jotterand-Bellomo 1986 \\
M. minutoides & $24-25$ & 32 & NW Zambia & Castiglia et al. 2002b \\
M. minutoides bellus (Cabrera, 1924) & $30-32$ & $?$ & Tanzania & Matthey 1966, 1967 \\
\hline
\end{tabular}

of the sub-genus Nannomys (Veyrunes et al. 2004) (Table 14, Fig. 17). By all karyotypic features these individuals belong to the "minutoides" group (Table 14). In both M. minutoides and M. musculoides, lineages polymorphism would be found and a contact or a gap zone would occur between both species either in central or north Tanzania.

Genus Rattus Fischer, 1803

Rattus rattus (Linnaeus, 1758)

Mus rattus Linnaeus, 1758: 61.

The black rat is well known in east Africa were it came from a variety of countries brought by human traffic along the Indian Ocean coast. Three individuals were trapped, all in the village houses. They all correspond to the black rat morphology and their karyotype show some variability. Two of the three animals karyotyped display $2 \mathrm{n}=38$ and 39, and $\mathrm{FNa}=58$ and 60 respectively (Fig. 18). The $2 n=39$ individual possesses one supernumerary or B chromosome, a phenomenon detected in numerous subspecies and populations of $R$. rattus (Yosida 1977).

\section{Family NesOMYIDAE Major, 1897} Subfamily CRICETOMYINAE Roberts, 1951

\section{Genus Beamys Thomas, 1909}

Among the pouched rats of the endemic African family, Beamys is the rarest and one of the two species of the genus is classified as Vulnerable by the IUCN. The holotype of $B$. hindei Thomas, 1909 comes from Taveta in Kenya while B. major 

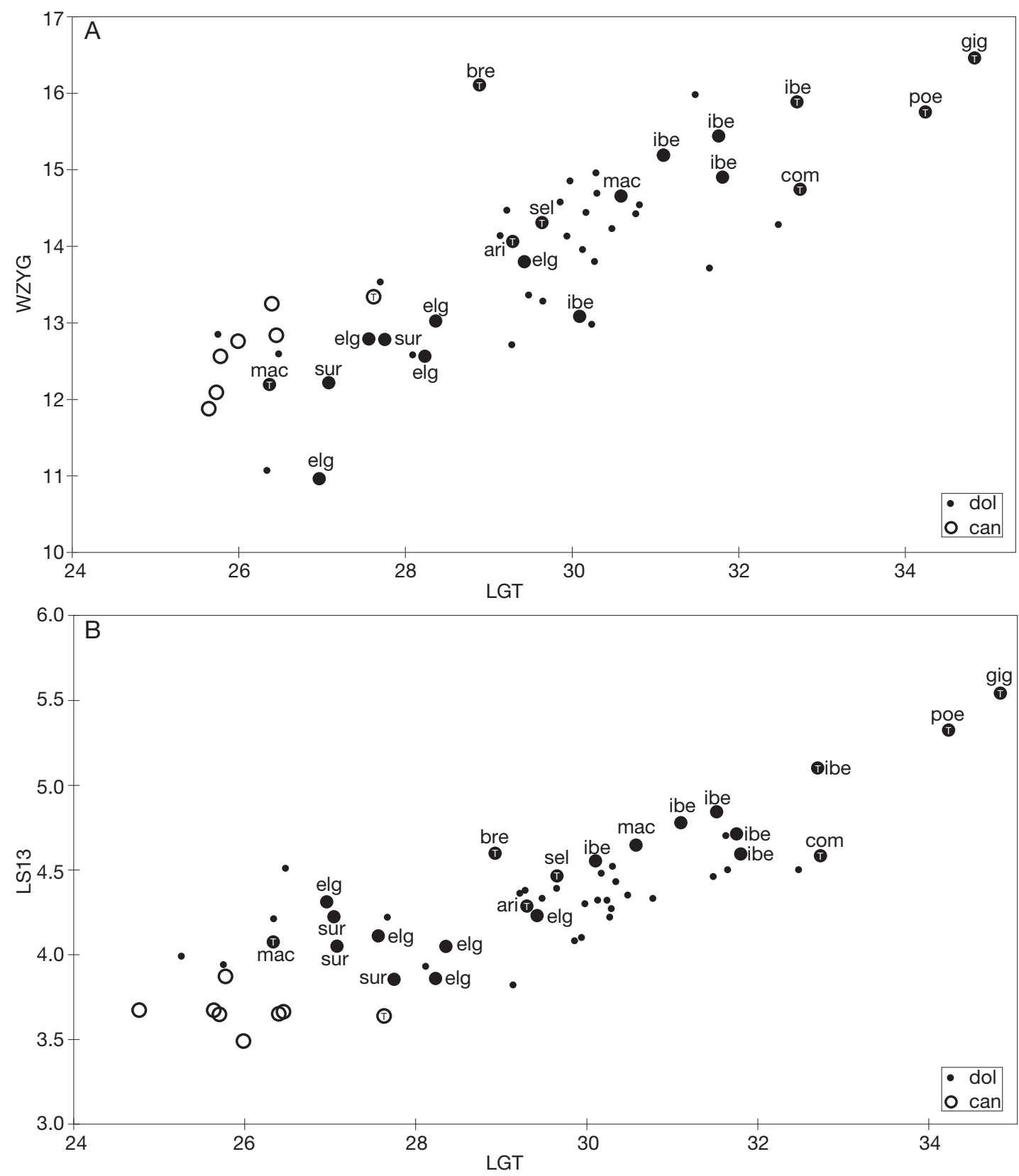

FIG. 15. - Scatterplots of skull proportions for different Grammomys Thomas, 1915: A, WZYG versus LGT (in millimetres); B, LS13 versus LGT. Abbreviations: see Material and methods. Symbol: T, holotype.

Dollman, 1914 holotype is from Mulanje in Malawi. claiming it is the earliest specimen of the genus Dieterlen (1979) described an old skull collected Beamys described in 1909 by Thomas. Classical in Moshi, Tanzania and attributed it to $B$. hindei determination keys emphasize a difference in size and 
TABLE 15. - External measurements (in millimetres) of Beamys major Dollman, 1914 and B. hindei Thomas, 1909 specimens from type series localities. Abbreviations: see Material and methods.

\begin{tabular}{|c|c|c|c|c|c|c|}
\hline Species & Specimen & Country & HВ & TL & $\mathbf{E}$ & HF \\
\hline B. hindei & MNHN-CG2007-1232 & Tanzania & 138 & 113.5 & 20.5 & 23 \\
\hline B. hindei & MNHN-CG2007-1251 & Tanzania & 125 & 118 & 19.5 & 21.5 \\
\hline B. hindei & MNHN-CG2007-1257 & Tanzania & 137 & $70+$ & 22 & 23 \\
\hline B. hindei & BMNH 10.9.22.32 & British East Africa & 131 & 129 & & 21.5 \\
\hline B. hindei & BMNH 1993-22 & Kenya & 140 & 128 & & 21 \\
\hline B. hindei & BMNH 1993-23 & Kenya & 129 & 128 & 20 & 21 \\
\hline B. hindei & BMNH 1993-18 & Kenya & 123 & 123 & 19 & 20 \\
\hline B. hindei & BMNH 1993-25 & Kenya & 137 & 120 & 21 & 21 \\
\hline B. hindei & BMNH 1993-21 & Kenya & 125 & 120 & 20 & 21 \\
\hline B. hindei & BMNH 1993-20 & Kenya & 131 & 116 & 20 & 20 \\
\hline B. hindei & BMNH 1993-24 & Kenya & 112 & 125 & 22 & 22 \\
\hline B. major & BMNH 62.333 & Malawi & 168 & 135 & 19 & 25 \\
\hline B. major & BMNH 61.463 & Malawi & 135 & 142 & 19.5 & 24 \\
\hline B. major & BMNH 61.462 & Malawi & 136 & 110 & 20 & 23.5 \\
\hline B. major & BMNH 78.2750 & Malawi & 117 & 124 & & 22 \\
\hline
\end{tabular}

TABLE 16. - Skull measurements (in millimetres) of Beamys hindei Thomas, 1909 and B. major Dollman, 1914 specimens from Tanzania and Malawi. Abbreviations: see Material and methods.

\begin{tabular}{|c|c|c|c|c|c|c|c|c|c|c|c|c|}
\hline ec & ountry & LG] & WZ & UIT & INA & LNAS & WBR & LS13 & LBT & 0 & NT4 LMDB HN & 3 LI13 \\
\hline & 1 & & & & 4.55 & 67 & & 4.75 & 5.85 & 4.13 & 3.51 & 4.95 \\
\hline & & & & & & & & & & & & \\
\hline 7 & & & & & & & & & & & & \\
\hline & & & & & & & & & & 3 & & \\
\hline & & 3 & 18. & & 4.57 & & & 5.37 & & & & 5.41 \\
\hline 463 major & & & & & 4.14 & & & 5.54 & 5.92 & & & 5.51 \\
\hline $\begin{array}{l}\text { MNH 9.6.12.23 } \\
\text { MNH 10.9.22.32 hindei }\end{array}$ & $\begin{array}{l}\text { BEA } \\
\text { BEA }\end{array}$ & $\begin{array}{l}32.05 \\
34.08\end{array}$ & 14.65 & $\begin{array}{l}4.79 \\
5.13\end{array}$ & 3.8 & 11.85 & 12.81 & $\begin{array}{l}4.71 \\
4.98\end{array}$ & 6.26 & 3 & 1.13 & 6 \\
\hline
\end{tabular}

especially in hindfoot length to separate between the two species. New discoveries of $B$. hindei in coastal Kenya as well as in south Tanzania by Fitzgibbon et al. (1995) suggest that there is a clinal variation in size from north to south coastal populations. Animals from lower latitudes appeared to be larger than those from near the Equator but the sample was too small to be statistically significant.

\section{Beamys cf. hindei Thomas, 1909}

Beamys hindei Thomas, 1909: 61.

Three relatively young individuals (one male and two females) of the lesser pouched rat were collected exclusively in the Kichi Forest. Their general size fits within the lower range of the species value provided by Kingdon (1974). By studying the distribution and morphology of $B$. hindei from new localities of Kenya and Tanzania, Fitzgibbon et al. (1995) concluded that there is a size cline among the populations from north to south. Because of the taxonomic confusion about which species is present in coastal area of Tanzania, we have compared our specimen with the two Beamys species holotypes and the populations of Kenya, south Tanzania and Malawi. As suggested by its name, B. major is larger compared to Tanzanian $B$. hindei specimens, despite some overlap in the HB and TL proportions (Table 15). We confirmed that $B$. hindei HF is 

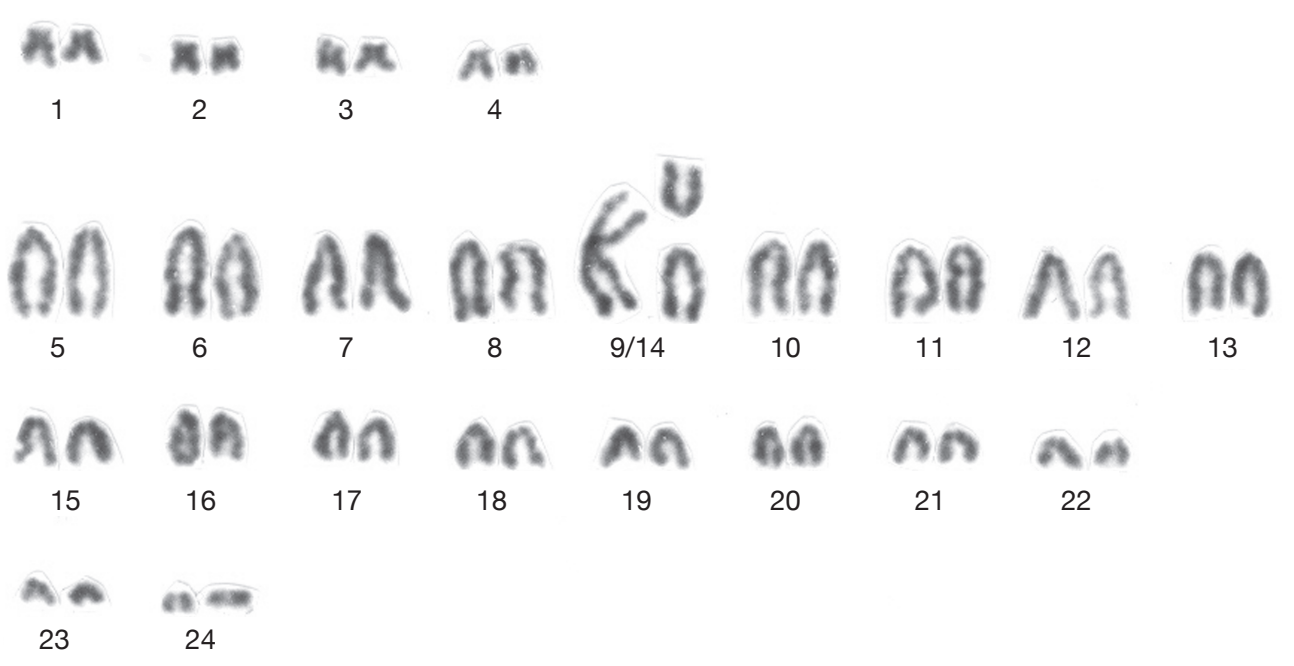

FIG. 16. - Standard karyotype of Grammomys selousi n. sp. (MNHN-CG2007-1231) holotype.
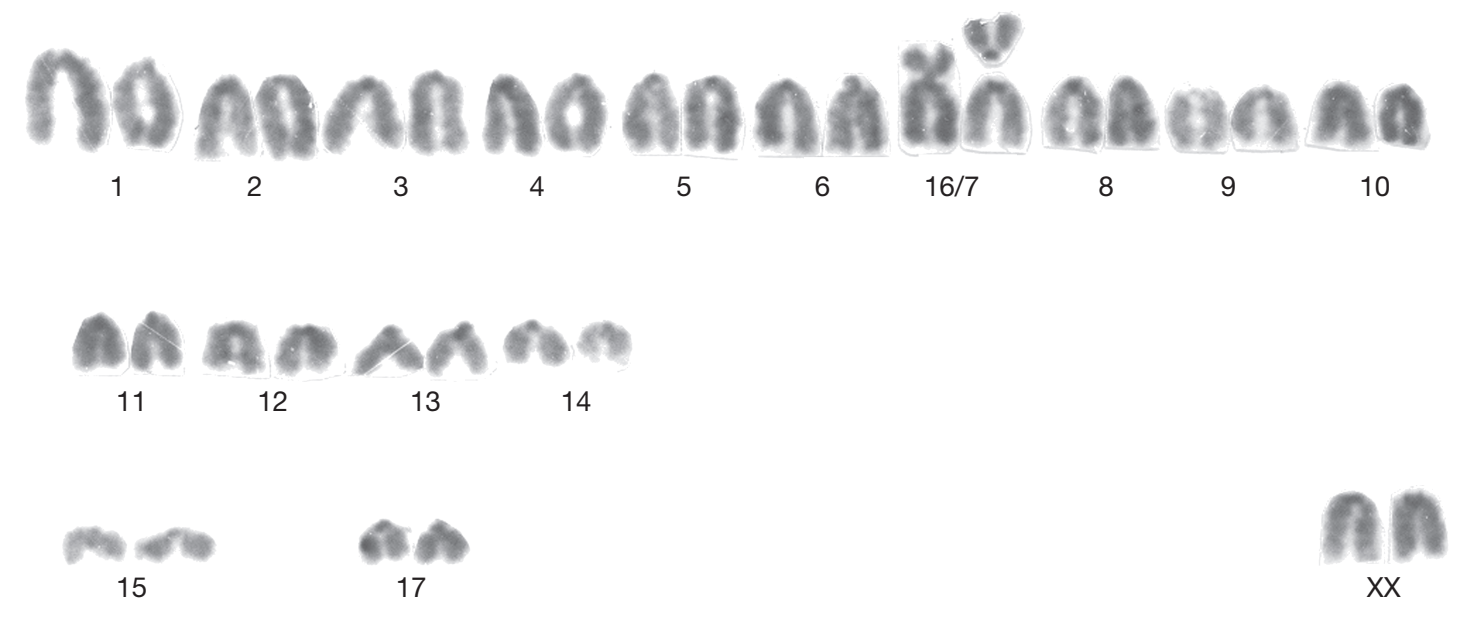

FIG. 17. - Standard karyotype of KP Mus minutoides Smith,1834 specimen (MNHN-CG2007-1061).

smaller than that of B. major, but the KP specimens fit well between the two groups. When comparing the skulls and molars proportions (Table 16) it is clear that the Selous Kingu Pira Beamys share with $B$. hindei the smaller molars and slightly smaller general size of the skull.

Fitzgibbon et al. (1995) have made standard karyotypes of four specimens of Arabuko, Sokoke Forest, Kilifi district, Kenya (BMNH 1993.18 to 25, cf. Table 15) and found a diploid chromosome number of $2 n=52$ with no more precision. The karyotype of Kingu Pira Beamys cf. hindei displays a chromosomal set consisting of 54 autosomes and two gonosomes $(2 \mathrm{n}=56, \mathrm{FNa}=72)$ (Fig. 19). Both sex chromosomes, metacentric $X$ and submetacentric $Y$, are the largest in the set and thus may probably represent distinctive karyotypic feature of this species. Because the type specimen of $B$. hindei comes from Taveta in SE Kenya (at the Tanzanian border), we may confirm that the Kenya specimens of $B$. hindei may represent 
TABLE 17. - External standard Gerbilliscus Thomas, 1897 measurements (in millimetres). Abbreviations: see Material and methods.

\begin{tabular}{|c|c|c|c|c|c|c|}
\hline Taxon/specimen & Country & Value & HB & TL & $\mathbf{E}$ & HF \\
\hline \multirow[t]{2}{*}{ G. leucogaster MNHN-CG2007-1134 \& 2007-1135 } & Tanzania & & 107.5 & 116.5 & 21 & 30.5 \\
\hline & Tanz & & 115 & 134 & 21.5 & 32.5 \\
\hline \multirow{3}{*}{$\begin{array}{l}\text { G. robustus Cretzschmar, } 1826 \text { after Bates } 1985 \\
(\mathrm{~N}=74)\end{array}$} & E Afr & mean & 148.6 & 178.1 & 21.1 & 35.4 \\
\hline & & & 111 & 150 & 15 & 25 \\
\hline & & & 180 & 203 & 25 & 40 \\
\hline \multirow{3}{*}{$\begin{array}{l}\text { G. nigricaudus Peters, } 1878 \text { after Bates } 1985 \\
(\mathrm{~N}=24)\end{array}$} & E Africa & mean & 157.7 & 193.9 & 22 & 37.5 \\
\hline & & $\mathrm{mi}$ & 130 & 170 & 19.5 & 34 \\
\hline & & $\mathrm{m}$ & 193 & 212 & 24 & 40.5 \\
\hline 1998-1603 (genetically typed specimen) & ) Tanzania, Ber & & 145 & 184 & 20 & 34.5 \\
\hline M & Tanz & & 13 & 162 & 20.5 & 29.4 \\
\hline MNHN-CG1998-1602 & a, Berega & & 140 & 166 & 34 & 21 \\
\hline G. leucogaster (Peters, 1852) MNHN-CG1990- 618 & Zimbabwe & & 120 & 161 & 20 & 32.5 \\
\hline G. leucogaster MNHN-CG1990-619 & Zimbabwe & & 124 & 138 & 19 & 36 \\
\hline G. I. nyasae (Wroughton, 1906) BMNH11.3.14.5 & MA, Karonga & & 127 & 149 & 21 & 32.5 \\
\hline G. I. nyasae BMNH & MA, Karonga & & 187 & 126 & 22 & 35 \\
\hline G. I. nyasae BMNH10.9.21.2 & Tanzania, S Rukuru & & 115 & 138 & 18 & 31 \\
\hline
\end{tabular}

a different species than the southern Tanzanian ones. Such a chromosomal differentiation may result from the fragmented distribution of the species.

\section{Subfamily GerbiLLINAE Gray, 1825 \\ Genus Gerbilliscus Thomas, 1897}

\section{Gerbilliscus leucogaster (Peters, 1852)}

\section{Meriones leucogaster Peters, 1852: 274.}

In the Selous, there are four potential species of Gerbilliscus that can be found according to Kingdon (1974): G. validus Bocage, 1890, G. inclusus Thomas \& Wroughton, 1908, G. robustus Cretzschmar, 1826 and $G$. nigricaudus Peters, 1878. According to Bates (1985), there is a size difference in the external measurements between $G$. robustus and G. nigricaudus. The bushveld gerbil Gerbilliscus leucogaster occurs in southern savannas and was recorded in SW Tanzania and north Malawi according to Musser \& Carleton (2005). It was not found in Masai Steppe (north Tanzania) by Fadda et al. (2001) but was recovered in Dakawa by Corti et al. (2005) and Colangelo et al. (2005). Gerbilliscus boehmi Noack, 1887 was also known in Tanzania (Swynnerton \& Hayman 1951) but is clearly distinguished from our specimen by its unique feature of double grooved incisors.
Only two young Gerbilliscus individuals (one male and one female) were caught in line C. One shows a medium haired brown tail with a tuft at the end, the other, smaller, has a yellow light tail with no tuft at the end. Both show a small HF compared to $G$. inclusus and $G$. nigricaudus specimens.

Their feet are dark coloured, which places them into the $G$. robustus group, according to Kingdon (1974). Both KP specimens show a small HF compared to $G$. validus, $G$. nigricaudus and $G$. inclusus specimens. They are slightly smaller than $G$. robustus and $G$. nigricaudus. By comparison with south Tanzanian G. leucogaster, the size of the KP specimens is rather smaller, as is the HF (Table 17).

After the chromosome number and morphology, the two specimens karyotyped here belong to G. leucogaster studied by Qumsiyeh (1986) and Colangelo et al. (2005) (Table 18, Fig. 20).

Family SCIURIDAE Fischer, 1817

Tribe PROTOXERINI Moore, 1959

Genus Paraxerus Forsyth Major, 1893

\section{Paraxerus flavovittis (Peters, 1852)}

Sciurus flavovittis Peter, 1852: 274.

One individual was trapped in Line G (open dry woodland). This individual exhibits the typical brown 
A

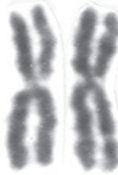

1

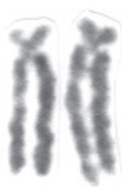

10

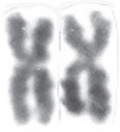

2

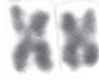

3

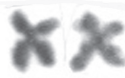

4

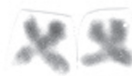

5

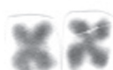

6

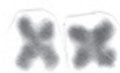

7

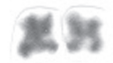

8

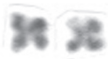

9

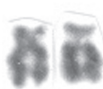

11

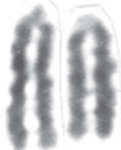

12

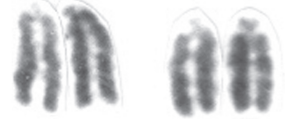

13

14

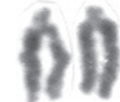

15

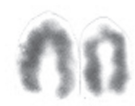

16

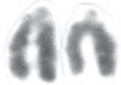

17
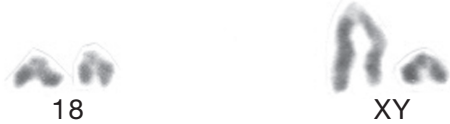

$\mathrm{XY}$

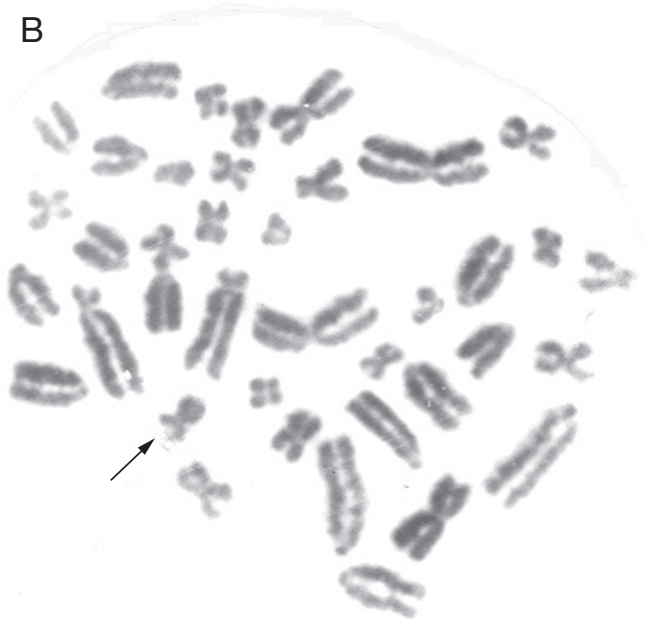

FIG. 18. - Standard karyrotype of KP Rattus rattus Linnaeus, 1758 specimens: A, ơ (MNHN-CG2007-1210); B, (CG2007-1209). The arrow indicates the supernumerary or B chromosom.

yellow dorsal pelage and displays a white stripe on the flanks which identifies it as P. flavovittis Peters, 1852 rather than $P$. cepapi Smith, 1836 or P. ochraceus Huet, 1880 , which also live in the region. It is also different from the red-bellied coast squirrel $P$. palliatus
Peters, 1852, that is found in the coastal forests of Kenya, Tanzania and Mozambique. Kingdon (1974) described intermediate forms between Paraxerus cepapi, a typical squirrel of the southern savannas and miombo woodlands occurring between the Rufiji river 
TABLE 18. - Standard karyotype data for east and south African Gerbilliscus Thomas, 1897 species from the literature and this work. Abbreviations: see Material and methods.

\begin{tabular}{|c|c|c|c|c|}
\hline Taxon/specimen & $2 n$ & $\mathrm{FNa}$ & Country & Authors \\
\hline G. leucogaster MNHN-CG2007-1134 \& 2007-1135 & 40 & 66 & Tanzania & This work \\
\hline G. robustus Cretzschmar, 1826 & 36 & 68 & Chad & Granjon \& Dobigny 2003 \\
\hline G. robustus & 36 & 64 & Kenya & Qumsieyeh et al. 1987 \\
\hline G. robustus & 36 & 68 & Ethiopia & Colangelo et al. 2005 \\
\hline G. gambiana (Thomas, 1910) & 52 & 64 & Senegal & Matthey \& Petter 1970 \\
\hline G. nigricaudus Peters, 1878 & 40 & 68 & Kenya & Qumsiyeh et al. 1987 \\
\hline G. nigricaudus & 36 & 68 & Tanzania & Corti et al. 2005 \\
\hline G. leucogaster (Peters, 1852) & 40 & 66 & RSA Namibia & Qumsiyeh 1986 \\
\hline G. leucogaster & 40 & 66 & Tanzania & Colangelo et al. 2005 \\
\hline G. leucogaster & $40-42$ & 66 & RSA & Gordon \& Rautenbach 1980 \\
\hline G. robustus? & 46 & 68 & west Africa & Matthey \& Petter 1970 \\
\hline G. kempi Wroughton, 1906 & 36 & 66 & CAR & Matthey \& Petter 1970 \\
\hline G. brantsii Smith, 1836 & 44 & $66 ?$ & RSA & Qumsiyeh 1986 \\
\hline G. vicinus (Peters, 1878) & 36 & 68 & Kenya, TZ & Corti et al. 2005 \\
\hline G. afra Gray, 1830 & 44 & $66 ?$ & RSA & Qumsiyeh 1986 \\
\hline
\end{tabular}

and east of lake Malawi, and P. palliatus, which he interpreted as a hybridization zone between the two species. Similarly, he indicates that Paraxerus flavovittis is common in all habitats between Rufiji and Rovuma rivers, but very rare in the north of Tanzania and is not known in the south of Mozambique.

A comparison of external and skull dimensions shows that our specimen fits well with the Tanzanian P. flavovittis specimens and the latter species is smaller than P. palliatus and P. ochraceus. Paraxerus flavovittis has a longer tooth row than P. palliatus and rounder, larger tympanic bullae (Table 19), but the size range of these two species are not well documented.

The standard karyotype of $P$. flavovittis $(2 \mathrm{n}=38)$ consists in 19 pairs, which, except one pair of acrocentric autosomes, are bi-armed, thus giving $\mathrm{FNa}=70$ (Fig. 21). To our knowledge, it is the first description of karyotype in the genus Paraxerus.

\section{Order SORICOMORPHA Gregory, 1910 Family SORICIDAE G. Fischer, 1814 Genus Crocidura Wagler, 1832}

\section{Crocidura hirta Peters, 1852}

\section{Crocidura hirta Peters, 1852: 78.}

Despite a great number of individuals, there is very little morphological and size variability among the collected specimens (Table 20), which belong to a relatively large sized shrew species.

Twelve studied specimens invariably display similar karyotype characterised by $2 \mathrm{n}=50$ and $\mathrm{FNa}=62$ (Fig. 22). Chromosome banding studies are needed to establish phylogenetic affinities with the other congeneric species occurring in east and west Africa and having similar or slightly different karyotypes after standard chromosome analysis. Meylan (1971), Meylan \& Vogel (1982), Maddalena et al. (1987) and Schlitter et al. (1999) also studied the karyotypes of the large representatives of the genus in many parts of Africa and found some variations in the chromosome numbers (Table 21). Here the KP specimens have similarities with the west and east African shrews of the "olivieri" complex like C. spurelli Thomas, 1910, C. manni Peters, 1878, C. kivu Osgood, 1910 and C. olivieri Lesson, 1827, which share a common karyotype of $2 \mathrm{n}=50, \mathrm{FN}=66, \mathrm{FNa}=62$. A comparison with $C$. flavescens I. Geoffroy, 1827 from South Africa shows that the karyotype differs from that of the previous species by displaying a $2 \mathrm{n}=50$ with $\mathrm{FN}=74$ and $\mathrm{FNa}=62$ (Maddalena et al. 1987). Meylan \& Vogel (1982) have grouped the forms kivu, spurelli, olivieiri and manni under the name C. occidentalis (Pucheran, 1855) but the correct name according to Maddalena et al. (1987) would be $C$. olivieri. 


\section{$k R$}

1

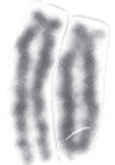

2

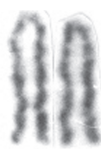

10

11
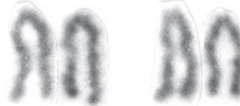

12

21

22

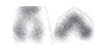

27
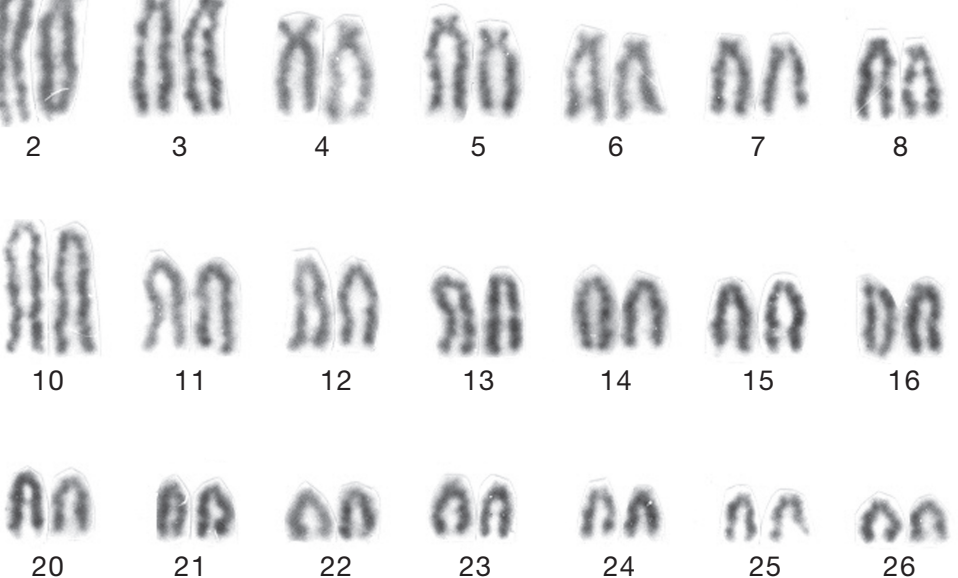

5

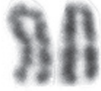

13

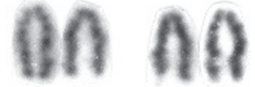

15

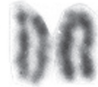

16

17

18

19

FIG. 19. - Standard karyotype of Beamys cf. hindei Thomas, 1909 specimen from Kichi forest (MNHN-CG2007-1232).
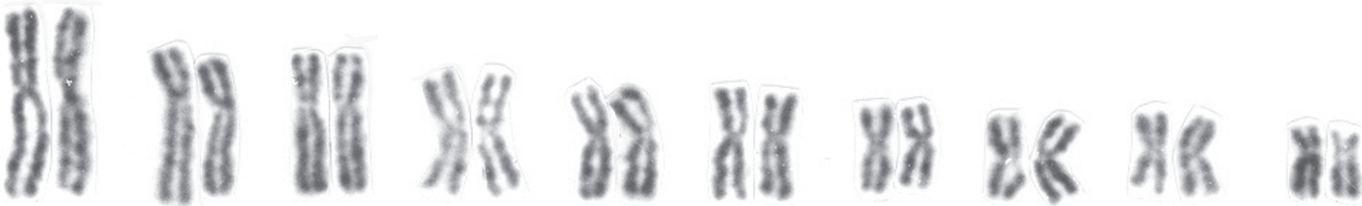

1

3

4

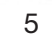

6

7

8

9

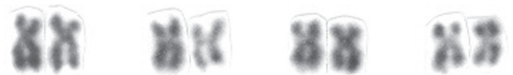

11

12

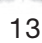

14

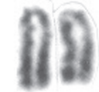

15
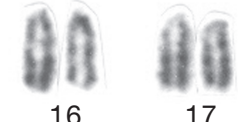

17
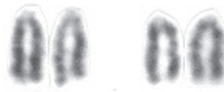

19

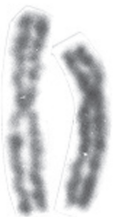

$X Y$ 
TABLE 19. - External measurements (in millimetres) for Paraxerus spp. Forsyth Major, 1893 from Tanzania, Kenya and Mozambique. Abbreviations: see Material and methods.

\begin{tabular}{|c|c|c|c|c|c|c|}
\hline Taxon/specimen & Locality & Country & HB & TL & HF & $\mathbf{E}$ \\
\hline \multicolumn{7}{|c|}{ Paraxerus flavovittis (Peters, 1852) } \\
\hline MNHN-CG2007-1236 & Kingu Pira & Tanzania & 169 & 161 & 42 & 19 \\
\hline ZBM88739 & & Tanzania & 166 & 180 & 40 & 15 \\
\hline DM681301 & & Tanzania & 200 & 160 & 40 & 20 \\
\hline ZFMK64838 & & Tanzania & 177 & 114 & 38 & 18 \\
\hline \multicolumn{7}{|c|}{ Paraxerus palliatus Peters, 1852} \\
\hline BMNH65.3015 & Kizimbani & Tanzania & 146 & 165 & 39 & 16 \\
\hline BMNH65.3011 & Kitandi & Tanzania & 169 & 166 & 41 & 16 \\
\hline BMNH54.763 & Nambunga & Tanzania & 180 & 145 & 34 & 25 \\
\hline BMNH65.3006 & Nangale & Tanzania & 164 & 153 & & 16 \\
\hline BMNH65.3005 & Nangale & Tanzania & 142 & 131 & 39 & 16 \\
\hline BMNH65.3014 & Kizimbani & Tanzania & 158 & 151 & 39 & 16 \\
\hline BMN65.2999 & Mayombo & Tanzania & 173 & 179 & 28 & 15 \\
\hline BMNH34.1.11.22 & & Mozambique & 165 & 165 & 38 & 18.5 \\
\hline \multicolumn{7}{|c|}{ Paraxerus cepapi Smith, 1836} \\
\hline ZBM5342 & & Kenya? & 156 & 167 & 32 & 16 \\
\hline \multicolumn{7}{|c|}{ Paraxerus ochraceus Huet, 1880} \\
\hline ZFMK60171 & Arusha & Tanzania & 163 & 115 & 36 & 19 \\
\hline ZFMK60178 & Arusha & Tanzania & 129 & 142 & 35 & 16 \\
\hline
\end{tabular}

To clarify the latter point, a molecular study based on mtDNA cytochrome b and mitochondrial control region (ctr) has been performed with KP106, KP122 and KP159 specimens (Dubey et al. 2007) included in a large panel of C. olivieri s.l. group from various geographic origins. This work provided evidence of different well-sustained groups among which, the close proximity of the KP specimens with $C$. hirta from the north of South Africa. Crocidura hirta has been already collected by Stanley et al. (1996) in the Chome Forest, South Pare Mountains, Tanzania, with only one specimen captured close to a river.

\section{DISCUSSION}

A comparison of our results with studies in Masai steppe and Serengeti (northwestern Tanzania) by Misonne \& Verschuren (1966), Fadda et al. (2001) and Magige \& Senzota (2006) shows some differences with the KP species communities. However, our sample is very limited and we may not have recovered the whole small mammals diversity of the area. However, the coastal Kichi Forest harbours a new Grammomys species and a new cytotype of Beamys hindei. We did not recover the typical squirrel representative of the Zanzibar-Inhambane coastal forest mosaic, Paraxerus palliatus, nor the southern miombo woodland one (P. cepapi), but found P. flavovittis, which has a parapatric distribution with $P$. ochraceus, separated by the Rufiji river. These large transverse rivers and swamps around the Rufiji river may also act as a barrier to some other rodent species, especially the arid adapted ones like Gerbillinae species, which are known to be unable to swim (Duplantier \& Bâ 2001). Gerbilliscus robustus and G. nigricaudus are present in the north of Tanzania (Corti et al. 2005), while Gerbillus pusillus is present in the Serengeti only (Fadda et al. 2001), but all species were absent from our survey; we found only $G$. leucogaster which is here in its northern limit of range.

For Acomys sp., the Ruifi river seems not to have played a role of barrier, because our Kingu Pira populations are very close from the northern populations of Dakawa and Morogoro, situated about $300 \mathrm{~km}$ north west. The same situation occurs for the very anthropic Mastomys natalensis and Mus minutoides.

A new bridge on Rufiji river has been inaugurated in 2003, a few days after our survey. By allowing trucks to cross the river, this may allow some other 


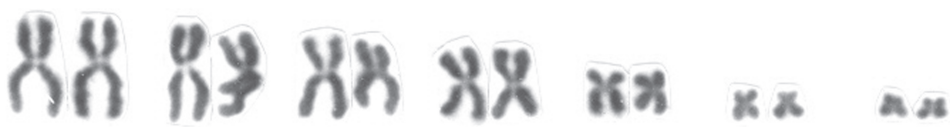 \\ 1 \\ 2 \\ 3 \\ 4 \\ 5 \\ 6 \\ 7

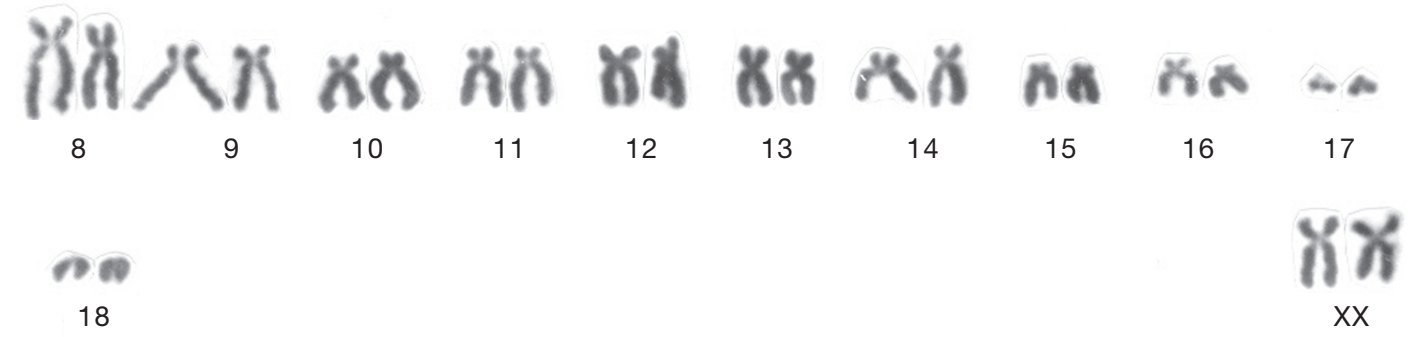

FIG. 21. - Standard karyotype of KP Paraxerus flavovittis (Peters, 1852) specimen (MNHN-CG2007-1236).

\section{หน $8 x$ in $\mathrm{x}$ \\ 1

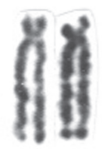

5

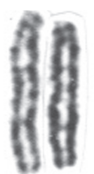

8

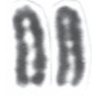

18

An

24

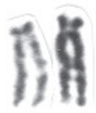

6

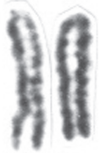

9

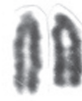

19

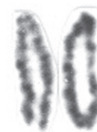

10

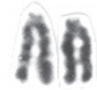

20

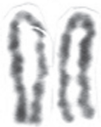

11

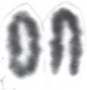

21

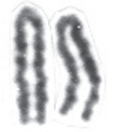

12

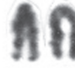

22

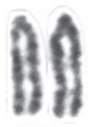

13

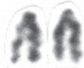

23

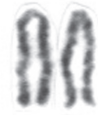

14

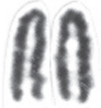

15

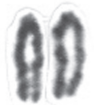

16

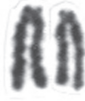

17

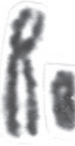

$X Y$

FIG. 22. - Standard karyotype of KP Crocidura hirta Peters, 1852 specimen (MNHN-CG2007-1212).

small mammals species to invade the Selous miombo woodlands and contribute to the reduction of its unique fauna. The intensification of car traffic and the proximity of the capital Dar es Salaam increased forest exploitation on the south side of the Rufiji river (Havnevik unpubl. data). 
TABLE 20. - Weight (in grams) and external measurements (in millimetres) for Crocidura hirta Peters, 1852 population of Kingu Pira. Abbreviations: see Material and methods.

\begin{tabular}{lccccc}
\hline & W & HB & TL & HF & E \\
\hline N individuals & 23 & 23 & 23 & 23 & 23 \\
Minimum & 10.0 & 76.0 & 51.5 & 14.5 & 8.0 \\
Maximum & 18.0 & 105.0 & 67.0 & 16.0 & 11.5 \\
Mean & 12.37 & 93.04 & 56.2 & 15.26 & 10.2 \\
CV & 0.157 & 0.088 & 0.064 & 0.039 & 0.092 \\
SD & 1.901 & 8.023 & 3.525 & 0.587 & 0.908 \\
\hline
\end{tabular}

TABLE 21. - Standard karyotypic data for Crocidura Wagler, 1832 from Africa. Abbreviations: see Material and methods.

\begin{tabular}{|c|c|c|c|c|}
\hline Taxon/specimen & Country & $2 n$ & FNa (or NF) & Authors \\
\hline C. hirta MNHN-CG2007-1145 & & 50 & 62 & this work \\
\hline C. hirta MNHN-CG2007-1219 & & 50 & 62 & this work \\
\hline C. hirta MNHN-CG2007-1101 & & 50 & 62 & this work \\
\hline C. bolivari Morales Agacino, 1934 & Morocco & 50 & (62) & Vogel et al. 1988 \\
\hline C. flavescens Geoffroy, 1827 & RSA & 50 & 62 & Maddalena et al. 1987 \\
\hline $\begin{array}{l}\text { C. wimmeri Heim de Balsac \& } \\
\text { Aellen, } 1958\end{array}$ & Ivory Coast & 50 & (84) & Meylan \& Vogel 1982 \\
\hline C. nigeriae Dollman, 1915 & Nigeria & 52 & (76) & Meylan \& Vogel 1982 \\
\hline C. poensis (Fraser, 1842) & Ivory Coast & 52 & (70) & Meylan \& Vogel 1982 \\
\hline C. occidentalis (Pucheran, 1855) & WC Africa & 50 & (66) & Meylan \& Vogel 1982 \\
\hline C. odorata Leconte, 1857 & Burkina Faso & 50 & (66) & Meylan \& Vogel 1982 \\
\hline C. cf. gracilipes Peters, 1870 & EC Nigeria & 52 & (68) & Meylan \& Vogel 1982 \\
\hline C. cf. nimbae Heim de Balsac, 1956 & Ivory Čoast & 46 & (68) & Meylan \& Vogel 1982 \\
\hline C. cf. planiceps Heller, 1910 & Ivory Coast & 44 & (72) & Meylan \& Vogel 1982 \\
\hline $\begin{array}{l}\text { C. crossi jouvenetae Heim de } \\
\text { Balsac, } 1968\end{array}$ & & 44 & (66) & Meylan 1971 \\
\hline C. lamottei Heim de Balsac, 1968 & & 52 & (68) & Meylan \& Vogel 1982 \\
\hline C. theresae Heim de Balsac, 1968 & & 50 & (82) & Meylan \& Vogel 1982 \\
\hline
\end{tabular}

The mosaic of landscapes, the number of barriers like rivers or highlands, observed in this region are highly in favour of an exceptional small mammals' diversity. By the fact, it has been shown in Congo and also in the Amazonian basin (South America) that mammal speciation may be promoted in fragmented blocs of forests separated by rivers (Colyn 1991; Gascon et al. 2000; Nicolas et al 2005; Katuala et al. 2008). Moreover, most of the rodents trapped here are primary consumers and dependent of the vegetation for their subsistence so, further molecular and morphometric studies are now required in order to test the cytogenetics hypotheses that a high cryptic component of the small mammals' species diversity still remains to be discovered in southern Tanzania.

\section{CONCLUSION}

From this survey, it has been possible to obtain for the first time new cytotypes for some genera (Paraxerus) or some species (Pelomys fallax, Crocidura hirta). This leads to the description of a new species of Grammomys in conjunction with morphological and morphometric analyses. This also allowed to precise some identifications as for Lemniscomys rosalia, Aethomys chrysophilus, Mus minutoides, Gerbilliscus leucogaster. This also raised new taxonomical problems for some species complexes as in the case of Acomys sp. and Beamys cf. hindei. This study demonstrates the necessity to improve our biodiversity survey efforts, using an integrative approach, even in relatively well-known countries like Tanzania. This also points the importance of 
mosaic, vegetation landscape and rivers barriers as structurating the diversity. This new study confirms that small mammals' taxonomy knowledge is far from being achieved in all tropical regions of Africa. Finally, we must also attract attention towards the coastal forest of south Tanzania, which is becoming increasingly threatened (Burgess et al. 1992, 1998) due to intensive palm tree, fruit and wood exploitations. However, our study shows that it hosts a new Grammomys species and also a possible new Beamys species, which highlights the importance of preserving this habitat as urgently as possible.

\section{Acknowledgements}

This field work was possible thanks to Adrar des Iforas association, P. Bouchet (MNHN), CNRS (UMR7205: OSEB), a COSTECH research permit no. 2003-152-CC-2003-83 (Prof. Kohi, Mr Nguli and Mr Black) and TAWIRI one, The Pest Management Center, Sokoine University of Agriculture and H. Leirs. Thanks to L. M. E. Severe, M. Pasanisi and P. Pfeffer. Field assistance was provided by Kevin Kessy, Rama Iddi who helped in trapping and administration, and two drivers Allan Makundi and Gobbless Ngowi. We also must thank Paula Jenkins (BMNH), R. Hutterer (ZFMK), P. Taylor (DM), R. Asher (ZMB), W. Stanley (FMNH) and $S$. Eiseb (SMMN) for their curatorial work and help in the collections.

\section{REFERENCES}

Aniskin V. M., LaVrenchenko L. A., Varshavskit A. A. \& MilishniKOV A. N. 1998. - [Karyotypes and cytogenetic differentiation of two African mouse species of the genus Mus (Rodentia, Muridae)]. Russian Journal of Genetics 34: 80-85 (in Russian).

Barôme P. O., Volobouev V., Monnerot M., Mfune J. K., Chitaulali W., Gautun J. C. \& Denys C. 2001. - Phylogeny of Acomys spinosissimus (Rodentia, Muridae) from north Malawi and Tanzania: evidence from morphological and molecular analysis. Biological Journal of the Linnean Society 3: 321-340.

BATES P. J. J. 1985. - Studies of gerbils of genus Tatera: the specific distinction of Tatera robusta (Cretzschmar, 1826), Tatera nigricauda (Peters, 1878) and Tatera phillipsi (De Winton, 1898). Mammalia 49: 37-52.
Britton-Davidian J., Catalan J., Granjon L. \& DUPLANTIER J. M. 1995. — Chromosomal phylogeny and evolution in the genus Mastomys (Mammalia, Rodentia). Journal of Mammalogy 76: 248-262.

BuRdA H. 2001. - Determinants of the distribution and radiation of African mole-rats (Bathyergidae), in Denys C., Poulet A. \& Granjon L. (eds), African Small Mammals. IRD Éditions, Paris: 261-277.

Burgess N. D., Mwasumbi L. B., Hawthorne W. D., Dickinson A. \& DoggetT R. A. 1992. - Preliminary assessment of the status, distribution and biological importance of the coastal forests of Tanzania. Biological Conservation 62: 205-218.

Burgess N. D., Clarke G. P. \& Rodgers W. A. 1998. - Coastal forests of eastern Africa: status, species endemism and its possible causes. Biological Journal of the Linnean Society 64: 337-367.

Carleton M. D. \& STANLEY W. T. 2005. - Review of the Hylomyscus denniae complex (Rodentia: Muridae) in Tanzania, with description of a new species. Proceedings of the Biological Society of Washington 118: 619-646.

Castiglia R., Fadda C., Corti M., Scanzani A., VERHEYEN W. \& CAPANNA E. 2002a. - Chromosomal evolution in the African Arvicanthine rats (Muridae, Rodentia): comparative cytogenetics of Lemniscomys (L. zebra, L. rosalia, L. striatus) and Arvicanthis dembeensis. Journal of Zoology Systematics and Evolutionary Research 40: 223-231.

Castiglia R., Gormung E. \& Corti M. 2002b. Cytogenetics analyses of chromosomal rearrangements in Mus minutoides/musculoides from north west Zambia through mapping of the telomeric sequence (TTAGGG)n and banding techniques. Chromosome Research 10: 399-406.

Castiglia R., Corti M., Colangelo, P., Annzei F., Capanna E., Verheyen W., Sichilima, A. M. \& MAKUNDI R. 2003. - Chromosomal and molecular characterization of Aethomys kaiseri from Zambia and Aethomys chrysophilus from Tanzania (Rodentia, Muridae). Hereditas 139: 81-89.

Chimimba C. \& Linzey A. V. 2008. - Aethomys ineptus (Rodentia: Muridae). Mammalian Species 809: 1-7.

Clausnitzer V. \& Kityo R. 2001. - Altitudinal distribution of rodents (Muridae and Gliridae) on $\mathrm{Mt}$ Elgon, Uganda. Tropical Zoology 14: 95-118.

Colangelo P., Corti M., Verheyen E., Annesi F., Oguge N., Makundi R. H. \& Verheyen W. 2005. - Mitochondrial phylogeny reveals differential modes of chromosomal evolution in the genus Tatera (Rodentia: Gerbillinae) in Africa. Molecular Phylogeny and Evolution 35: 556-568.

ColYN M. 1991. — L'importance zoogéographique du bassin du fleuve Zaïre pour la spéciation: le cas des primates simiens. Bulletin des Sciences zoologiques du Musée royal de l'Afrique Centrale 264: 4-10.

Corti M., Castiglia R. \& Verheyen W. 2004. — A note 
on three cytotypes of Lophuromys flavopunctatus sensu lato (Rodentia, Muridae) from Tanzania. Mammalia 68: 69-74.

Corti M., Castiglia, R., Colangelo P., Capanna E., Beolchini F., Bekele A., Oguge N. O., Makundi R. H., Sichilima A. M., Leirs H., Verheyen L. \& VERHAGEN R. 2005. - Cytotaxonomy of rodent species from Ethiopia, Kenya, Tanzania and Zambia. Belgian Journal of Zoology 135 (suppl.): 197-216.

DEMETER R. \& HUTTERER R. 1986. - Small mammals from Mt Meru and its environs (northern Tanzania). Cimbebasia 8:199-207.

Denys C. \& Tranier M. 1992. - Présence d'Aethomys (Mammalia, Rodentia) au Tchad et analyse morphométrique préliminaire du complexe $A$. hindei. Mammalia 56: 625-656.

Denys C., Lecompte E., Granjon L., Baylac M., Cordeiro P., Cornette R., Dobigny G., FichetCalvet E., Hugot J.-P., Meslage C., MillienParra V., Petrillo P., Volobouev V. \& Welz M. 2003. - Integrative systematics: the importance of combining various techniques for increasing knowledge of African Murinae, in Singleton G. R., Hinds L. A., Krebs C. J. \& Spratt D. M. (eds), Rats, Mice and People: Rodent Biology and Management. ACIAR, Canberra: 499-506.

Dieterlen F. 1979. - Der früheste Fund der afrikanischen kelinen Hamsterrratte (Beamys hindei) (Cricetomyinae, Cricetidae, Rodentia). Stuttgarter Beiträge für Naturkunde 330: 1-3.

DippenaAR N. J. \& Rautenbach I. L. 1986. - Morphometrics and karyology of the southern species of the genus Acomys I. Geoffroy Saint Hilaire, 1838 (Rodentia: Muridae). Annals of the Transvaal Museum 34: 129-183.

Dippenaar N. J., Meester J., Rautenbach I. L. \& Wolmuter D. A. 1984. - The status of southern African mammal taxonomy. Annales du Musée royal de l'Afrique Centrale, Sciences zoologiques 237: 103107.

Dobigny G., Granjon L., Aniskin V., BÂ K. \& VoloBOUEV V. 2003. - A new sibling species of Taterillus (Muridae, Gerbillinae) from West Africa. Mammalian Biology 68: 299-316.

Dubey S., Antonin M., Denys C. \& Vogel P. $2007 .-$ Use of phylogeny to resolve the taxonomy of the widespread and highly polymorphic African giant shrews (C. olivieri group, Crocidurinae, Mammalia). Zoology 110: 48-57.

Ducroz J.-F. 1998. - Contribution des approches cytogénétique et moléculaire à l'étude systématique et évolutive de genres de rongeurs Murinae de la "division" Arvicanthis. PhD Dissertation, Muséum national d'Histoire naturelle, Paris, $250 \mathrm{p}$.

Ducroz J.-F., Granjon L., LOMBARD M. \& VoloboueV V. 1999. - Comparative chromosome analysis (R- and C- bands) of two South African murid species, Lemniscomys rosalia and Rhabdomys pumilio (Rodentia, Murinae). Cytogenetics and Cell Genetics 87: 69-74.

DuplantiER J. M. \& BÂ K. 2001. — Swimming ability in six west African rodent species under laboratory condition: evaluation of their potentialities to colonize islands, in Denys C., Poulet A. \& Granjon L. (eds), African Small Mammals. IRD Éditions, Paris: 331-342.

Fadda C., Castiglia R., Colangelo P., Corti M., Machan'gu R., MaKundi R., Scanzani A., Tesha P., Verheyen W. \& CAPANNA E. 2001. — The rodent fauna of Tanzania : a cytotaxonomic report from Masai steppe (1999). Rendiconti Lincei Scienze Fisiche e Naturali 9: 29-49.

FitzGibbon C. D., Leirs H. \& Verheyen W. 1995. Distribution, population dynamics and habitat use of the lesser pouched rat, Beamys hindei. Journal of Zoology, London 236: 499-512.

FÜLLING O. 1992. - Ergähzande angaben über gaumenfaltenmuster von Nagetieren (Mammalia: Rodentia) aus Kamerun. Bonner Zoologische Beiträge 43: 415-421.

Gascon C., Malcolm J. L., Patton M. N. F., Da Sylva J. P., Bogart S. C., Lougheed C. A., Peres S. \& Boag P. T. 2000. - Riverine barriers and the geographic distribution of Amazonian species. Proceedings of the National Academy of Sciences of the United States of America 97: 13672-13677.

GoOdman S. M., NeWMark W. D., STANLEy W. T. \& Howell K. M. 1995. - The Ambangulu Forest, West Usambara Mountains, Tanzania: a threatened Eastern Arc Forest. Oryx 29: 212-214.

Gordon D. H. \& RaUTENBACH I. L. 1980. — Species complexes in medically important rodents: chromosome studies of Aethomys, Tatera and Saccostomus (Rodentia: Muridae, Cricetidae). South African Journal of Science 76: 559-561.

GORDON D. H. \& WaTSON C. R. B. 1986. — Identification of cryptic species of rodents (Mastomys, Aethomys, Saccostomus) in the Kruger National Park. South African Journal of Zoology 21: 95-99.

Granjon L. \& Dobigny G. 2003. - The importance of cytotaxonomy in understanding the biogeography of African rodents: lake Chad murids as an example. Mammal Review 33: 77-91.

Granjon L., Duplantier J. M., Catalan J. \& BrittonDAVIDIAN J. 1997. - Systematics of the genus Mastomys (Thomas,1915) (Rodentia, Muridae). Belgian Journal of Zoology 127: 7-18.

HANNEY P. 1965. - The Muridae of Malawi (Africa: Nyasaland). Journal of Zoology, London 146: $577-$ 633.

Heim de Balsac H. \& Aellen V. 1965. — Les Muridae de basse Côte d'Ivoire. Revue suisse de Zoologie 72: 695-753.

Huhndorf M. H., Kerbis Peterhans J. C. \& LoeW 
S. S. 2007. - Comparative phylogeography of three endemic rodents from the Albertine Rift, east central Africa. Molecular Ecology 6: 663-674.

Hutterer R. \& Dieterlen F. 1984. - Zwei neue Arten der Gattung Grammomys aus Äthiopien und Kenia (Mammalia: Muridae). Stuttgarter Beiträge für Naturkunde A 374: 1-18.

JOTTERAND-BELLOMO M. 1984. — L’analyse cytogénétique de deux espèces de Muridae africains, Mus oubanguii et Mus minutoides/musculoides: polymorphisme chromosomique et ébauche d'une phylogénie. Cytogenetics and Cell Genetics 38: 182-188.

JotTERAND-BELLOMO M. 1986. — Le genre Mus africain, un exemple d'homogénéité caryotypique: étude cytogénétique de Mus minutoides/musculoides (Côte d'Ivoire), de Mus setulosus (République Centrafricaine), et de Mus mattheyi (Burkina Faso). Cytogenetics and Cell Genetics 42: 99-104.

Kan Kouassi S., Nicolas V., Aniskine V., Lalis A., Cruaud C., Couloux A., Colyn M., Dosso M., Koivogui L., Verheyen E., AKoua-Koffi C. \& DENYS C. 2008. - Taxonomy and biogeography of the African Pygmy Mice, subgenus Nannomys (Rodentia, Murinae, Mus) in Ivory Coast and Guinea (West Africa). Mammalia 72: 237-252.

KasangaKi A., Kityo R. \& Kerbis J. 2003. - Diversity of rodents and shrews along an elevation gradient in Bwindi impenetrable National Park, south West Uganda. African Journal of Ecology 41 (2): 115-123.

Katuala P. G. B., Kennis J., Nicolas V., Wendelen W., Hulselmans J., Verheyen E., Van Houtte N., Dierck T., Dudu A. M. \& Leirs H. 2008. — The presence of Praomys, Lophuromys, and Deomys species (Muridae, Mammalia) in the forest blocks separated by the Congo River and its tributaries (Kisangani region, Democratic Republic of Congo). Mammalia 72: 223-228.

KingDON J. S. 1974. - East African Mammals. An Atlas of Evolution in Africa. Volume 2, part B: Hares \& Rodents. Academic Press, London: 343-704.

Kryštufek B., BaXter R. M., Haberl W., Zima J. \& BuŽAN E. V. 2008. — Systematics and biogeography of the Mozambique Thicket rat, Grammomys cometes, in eastern Cape province, South Africa. Journal of Mammalogy 89: 325-335.

Lalis A., Lecompte E., Cornette R., Moulin S., Machangu R. S., MaKundi R., Aniskine V. \& Denys C. 2006. - Polymorphism of the age population structure of two wild Mastomys natalensis (Rodentia: Muridae) Tanzanian habitat samples: a multicriteria comparison. Mammalia 70: 3-4, 293-299.

Lalis A., Baylac M. Cosson J. F., MaKundi R. H., MACHANG'U R. S. \& DenYS C. 2009. - Cranial morphometric and fine scale genetic variability of two adjacent Mastomys natalensis (Rodentia: Muridae) populations. Acta Theriologica 54: 171-181.

LAVRENCHENKO L. A., LiKhNOVA O. P., BASKEVICH M. I. \& BEKELE A. 1998. - Systematics and distribution of Mastomys (Rodentia, Murinae) from Ethiopia, with the description of a new species. Zeitschrift für Säugetierkunde 63: 37-51.

Lecompte É., Denys C., Granjon L. 2005. - Confrontation of morphological and molecular data: the Praomys group (Rodentia: Murinae) as a case of adaptive convergences and morphological stasis. Molecular Phylogeny and Evolution 37: 899-919.

LeE M. R. \& Elder F. F. B. 1980. — Yeast stimulation of bone marrow mitosis for cytogenetic investigations. Cytogentics and Cell Genetics 26: 36-40.

Leirs H, Stuyck J., Verhagen R. \& Verheyen W. 1990. - Seasonal variation in growth of Mastomys natalensis (Rodentia: Muridae) in Morogoro, Tanzania. African Journal of Ecology 28: 298-306.

Lima M, Stenseth N. C., Leirs. H. \& Jaksic F. M. 2003. - Population dynamics of small mammals in semi-arid regions: a comparative study of demographic variability in two species. Proceedings of the Royal Society of London B 270: 1997-2007.

Linzey A. V. \& Chimimba C. T. 2008. - Aethomys chrysophilus (Rodentia: Muridae). Mammalian Species 808: 1-9.

Maddalena T., Mehmeti A. M., Bronner G. \& Vogel P. 1987. - The karyotype of Crocidura flavescens (Mammalia, Insectivora) in South Africa. Zeitschrift für Saugetierkunde 52: 129-132.

Magige F. \& Senzota R. 2006. - Abundance and diversity of rodents at the human-wildlife interface in Western Serengeti, Tanzania. African Journal of Ecology 44: 371-378.

MATTHEY R. 1956. - La formule chromosomique de quelques Murinae (Muridae, Rodentia, Mammalia). Archives Johan Klaus Stift Verbreitung Forschung 31: 294-306.

MATTHEY R. 1958. — Les chromosomes et la position systématique de quelques Murinae africains. Acta Tropica 15: 97-117.

MATTHEY R. 1963. — La formule chromosomique chez sept espèces et sous-espèces de Murinae africains. Mammalia 27: 157-176.

MatTHEY R. 1964. - Analyse caryologique de cinq espèces de Muridae africains (Mammalia, Rodentia). Mammalia 28: 403-418.

MaTTHEY R. 1965. - Le problème de la détermination du sexe chez Acomys selousi de Winton: Cytogénétique du genre Acomys (Rodentia: Murinae). Revue suisse de Zoologie 72: 119-144.

MATTHEY R. 1966. - Nouvelles contributions à la cytogénétique des Mus africaines du sous-genre Leggada. Experientia 22: 1-6.

MATTHEY R. 1967. - Un nouveau système chromosomique polymorphe chez des Leggada africaines du 
groupe tenellus (Rodentia-Muridae). Genetica 38: 211-226.

MatTHey R. 1968. - Cytogénétique et taxonomie du genre Acomys. A. percivali Dollman et $A$. wilsoni Thomas, espèces d'Abyssinie. Mammalia 32: 621-627.

MATTHEY R. 1970a. - Nouvelles données sur la cytogénétique et la spéciation des Leggada (MammaliaRodentia-Muridae). Experientia 26: 102-103.

MATTHEY R. 1970b. - L'éventail robertsonien chez les Mus (Leggada) africains du groupe minutoidesmusculoides. Revue suisse de Zoologie 77: 625-629.

MATTHEY R. 1971. — Dimorphisme sexuel du chromosome X et du caryotype de Grammomys surdaster Th. et Wrough. (Mammalia: Muridae). Bolletino Zoologico 38: 183-186.

Matthey R. \& PetTer F. 1970. — Étude cytogénétique et taxonomique de 40 Tatera et Taterillus provenant de Haute-Volta et de République Centrafricaine (Rongeurs, Gerbillidae). Mammalia 36: 193-209.

MeESTER J. \& SeTZER H. W. 1971-1977. — The Mammals of Africa: an Identification Manual. Smithsonian Institution Press, Washington DC, not continuously paginated.

MeYlan A. 1971. - Chromosomes de Soricidés de Côte d'Ivoire (Mammalia, Insectivora). Revue suisse de Zoologie 78: 603-613.

Meylan A. \& Vogel P. 1982. - Contribution à la cytotaxonomie des Soricidés (Mammalia: Insectivora) de l'Afrique occidentale. Cytogenetics and Cell Genetics 34: 83-92.

Misonne X. 1969. - African and Indo-Australian Muridae evolutionary trends. Bulletin du Musée royal de l'Afrique Centrale, Sciences zoologiques 14: 1-118.

MisONNE X. \& VERSCHUREN J. 1966. - Les rongeurs et lagomorphes de la région du parc national du Serengeti (Tanzanie). Mammalia 30: 517-537.

Mugo D. N., Lombard A. T., Bronner G. N., Gelderblom C. M. \& Benn G. A. 1995. - Distribution and protection of endemic or threatened rodents, lagomorphs and macrosceledids in South Africa. South African Journal of Zoology 30: 115-126.

Mullin S. K., TaYlor P. J. \& Pillay N. 2004. — Skull size and shape of Dasymys (Rodentia, Muridae) from sub-Saharan Africa. Mammalia 68: 185-220.

Mulungu L. S., Makundi R. H., Massawe A. W., MACHANG'U R. S. \& MBiJE N. E. 2008. - Diversity and distribution of rodent and shrew species associated with variations in altitude on Mount Kilimanjaro, Tanzania. Mammalia 72: 178-185.

Musser G. G. \& CARLETON M. D. 2005. - Superfamily Muroidea, in WILSON D. E. \& ReEDER D. M. (eds), Mammal Species of the World. A Taxonomic and Geographic Reference. $3^{\text {rd }}$ edition. The Johns Hopkins University Press, Baltimore: 894-1531.

Myers N., Mittermeier R. A.,. Mittermeier C. G., FonseCA G. A. B. DA \& KENT J. 2000. — Biodiversity hotspots for conservation priorities. Nature 403: 853-858.

Nicolas V., Verheyen E., Verheyen W., Hulselmans J., Dillen M., Akpatou B., Dudu A., Wendelen W. \& Colyn M. 2005. - Systematics of African lowland rainforest Praomys (Rodentia, Muridae) based on molecular and craniometrical data. Zoological Journal of the Linnean Society 145: 549-553.

Olert J., Dieterlen F., Rupp H. 1978. — Eine neue Muriden-Art aus Südäthiopien. Zeitschrift für. Zoologische und Systematische Evolution Forschung 16: 297-308.

Olson D. M., Dinerstein E., Wikramanayake E. D., Burgess N. D., Powell G. V. N., UnderWoOd E. C., D'Amico J. A., Itoua I., STRAND H. E., Morrison J. C., Loucks C. J., AllnutT T. F., RicketTs T. H., Kura Y., LamoreuX J. F., Wettengel W. W., Hedao P. \& KASSEM K. R. 2001. - Terrestrial Ecoregions of the World: a new map of life on earth. Biosciences 51: 933-938.

Orlov V .N., Bulatova N. S. \& Milishnikov A. N. 1989. - [Karyotypes of some mammalian species (Insectivora, Rodentia) in Ethiopia], in SoKOLOV V. E. (ed), Ecological and Faunistic Studies in South-Western Ethiopia. USSR Committee for the Unesco Programe $\mathrm{MAB}$ and Institute of Evolutionary Morphology and Animal Ecology of the USSR Academy of Science, Moscow: 72-94 (in Russian).

OsGOOD W. H. 1910. — Diagnoses of new East African mammals, including a new genus of Muridae. Field Museum of Natural History Zoology 10: 5-13.

Petter F. \& Tranier M. 1975. - Contribution à l'étude des Thamnomys du groupe dolichurus (Rongeurs, Muridés). Systématique et caryologie. Mammalia 39: 405-414.

Qumsiyen M. B. 1986. - Phylogenetic studies of the rodent family Gerbillidae: I. Chromosomal evolution in the Southern African complex. Journal of Mammalogy 67: 680-692.

Qumsiyeh M. B., Hamilton M. J. \& Schlitter D. A. 1987. - Problems in using Robertsonian rearrangements in determining monophyly: examples from the genera Tatera and Gerbillurus. Cytogenetics and Cell Genetics 44: 198-208.

ROBERTS A. 1951. - The Mammals of South Africa. Trustees of "The Mammals of South Africa" Book Fund, Johannesbourg, $700 \mathrm{p}$.

Roche J., Capanna E., Civitelli M. V. \& Ceraso A. 1984. - Caryotypes des rongeurs de Somalie. 4. Première capture de rongeurs arboricoles du sousgenre Grammomys (genre Thamnomys, Muridés) en république de Somalie. Italian Journal of Zoology supplemento XIX: 259-277.

Rosevear D. R. 1969. - The Rodents of West Africa. British Museum (Natural History), London, XII, $604 \mathrm{p}$. 
SeABRight M. A. 1971. - A rapid banding technique for human chromosomes. Lancet 2: 971-972.

Schlitter D. A., Hutterer R., Magdalena T. \& RobBins L. W. 1999. - New karyotypes of shrews (Mammalia: Soricidae) from Cameroon and Somalia. Annals of the Carnegie Museum 68: 1-13.

Stanley W. T., Goodman S. M. \& Hutterer R. 1996. - Notes on the insectivores and elephant shrews of the Chome Forest, South Pare Mountains, Tanzania (Mammalia : Insectivora et Macroscelidae). Zoologische Abhandlungen. Staatliches Museum Tierkunde Dresden 49: 131-147.

Stanley W. T., Goodman S. M. \& Kihaule P. M. 1998. - Results of two surveys of rodents in the Chome Forest Reserve, South Pare Mountains, Tanzania (Mammalia: Rodentia). Zoologische Abhandlungen. Staatliches Museum Tierkunde Dresden 50: 145-160.

Stanley W. T., Rogers M. A., Howell K. M. \& MSUYA C. A. 2005. - Results of a survey of small mammals in the Kwamgumi forest reserve, East Usambara Mountains, Tanzania. Journal of East Africa Natural History 94 (1): 223-230.

StANley W. T. \& Foley C. A. H. 2008. - A survey of the small mammals of Minziro forest, Tanzania, with several additions to the known fauna of the country. Mammalia 72: 116-122.

StANLEY W.T. \& HutTerer R. 2000. — A new species of Myosorex Gray, 1832 (Mammalia, Soricidae) from the Eastern Arc Mountains, Tanzania. Bonner Zoologische Beiträge 49: 19-29.

SwYNnERTON G. H. 1958. - Fauna of the Serengeti National Park. Mammalia 22: 435-450.

Swynnerton G. H. \& Hayman R. W. 1951. - A checklist of the land mammals of the Tanganyika territory and the Zanzibar protectorate. Journal of East Africa Natural History 20: 274-392.

Thomas O. 1915. - New African rodents and insectivores, mostly collected by Dr C. Christy for the Congo Museum. Annals and Magazine of Natural History 8, XVI: 146-152.

TAYLOR P. J. 2000. - Patterns of chromosomal variation in Southern African rodents. Journal of Mammalogy 81: 317-331.

Tranier M. \& Dosso H. 1979. - Recherches caryotypiques sur les rongeurs de Côte d'Ivoire: résultats préliminaires pour les milieux fermés. Annales de l'Université
d'Abidjan série E (Écologie) 12: 181-183.

Tranier M. \& Gautun J. C. 1979. - Recherches caryotypiques sur les rongeurs de Côte d'Ivoire: résultats préliminaires pour les milieux ouverts. Le cas d'Oenomys hypoxanthus ornatus. Mammalia 43: 252-254.

Van der Straeten E. 1980. - A new species of Lemniscomys (Muridae) from Zambia. Annals of the Cape Province Museum of natural History 13: 55-62.

Van der Straeten E \& Verheyen W. N. 1978. Karyological and morphological comparisons of Lemniscomys striatus (Linnaeus, 1758) and Lemniscomys bellieri (Van der Straeten, 1975) from Ivory Coast (Mammalia: Muridae). Bulletin of the Carnegie Museum 6: 41-47.

Veyrunes F., Catalan J., Sicard B., Robinson T. J., Duplantier J. M., Granjon L., Dobigny G. \& Britton-Davidian J. 2004. - Autosome and sex chromosome diversity among the African pigmy mice, subgenus Nannomys (Murinae: Mus). Chromosome Research 12: 369-382.

VERHUYNES F., BRITTON-DAVIDIAN J., ROBINSON T. J., Calvet E., Denys C. \& Chevret P. 2005. - Molecular phylogeny of the African pygmy mice, subgenus Nannomys (Rodentia, Murinae, Mus): implications for chromosomal evolution. Molecular Phylogeny and Evolution 36: 358-369.

VisSER D. S. \& Robinson T. J. 1986. - Cytosystematics of the South African Aethomys (Rodentia : Muridae). South African Journal of Zoology 21: 264-268.

Vogel P., Maddalena T. \& Aulagnier S. 1988. - Le caryotype de Crocidura bolivari Morales Agacino, 1934 (Mammalia, Soricidae). Revue suisse de Zoologie 95: 779-783.

Volobouev V. 1980. — The B chromosome system of mammals, in VORONTSOV N. N. \& VAN BRINK J. M. (eds), Animal Genetics and Evolution. Dr. W. Junk B.V. Publishers, The Hague: 333-338.

Wilson D. E. \& ReEder D. M. 2005. - Mammal Species of the World. A Taxonomic and Geographic Reference. $3^{\text {rd }}$ edition. The John Hopkins University Press, Baltimore, $2142 \mathrm{p}$.

Yosida T. H. 1977. - Supernumerary chromosomes in the black rat (Rattus rattus) and their distribution in three geographic variants. Cytogenetics and Cell Genetics 18: 149-159. 